\title{
U.S. Geological Survey Toxic Substances Hydrology Program-- Abstracts of the Technical Meeting, Colorado Springs, Colorado, September 20-24, 1993
}

U.S. GEOLOGICAL SURVEY Open-File Report 93-454
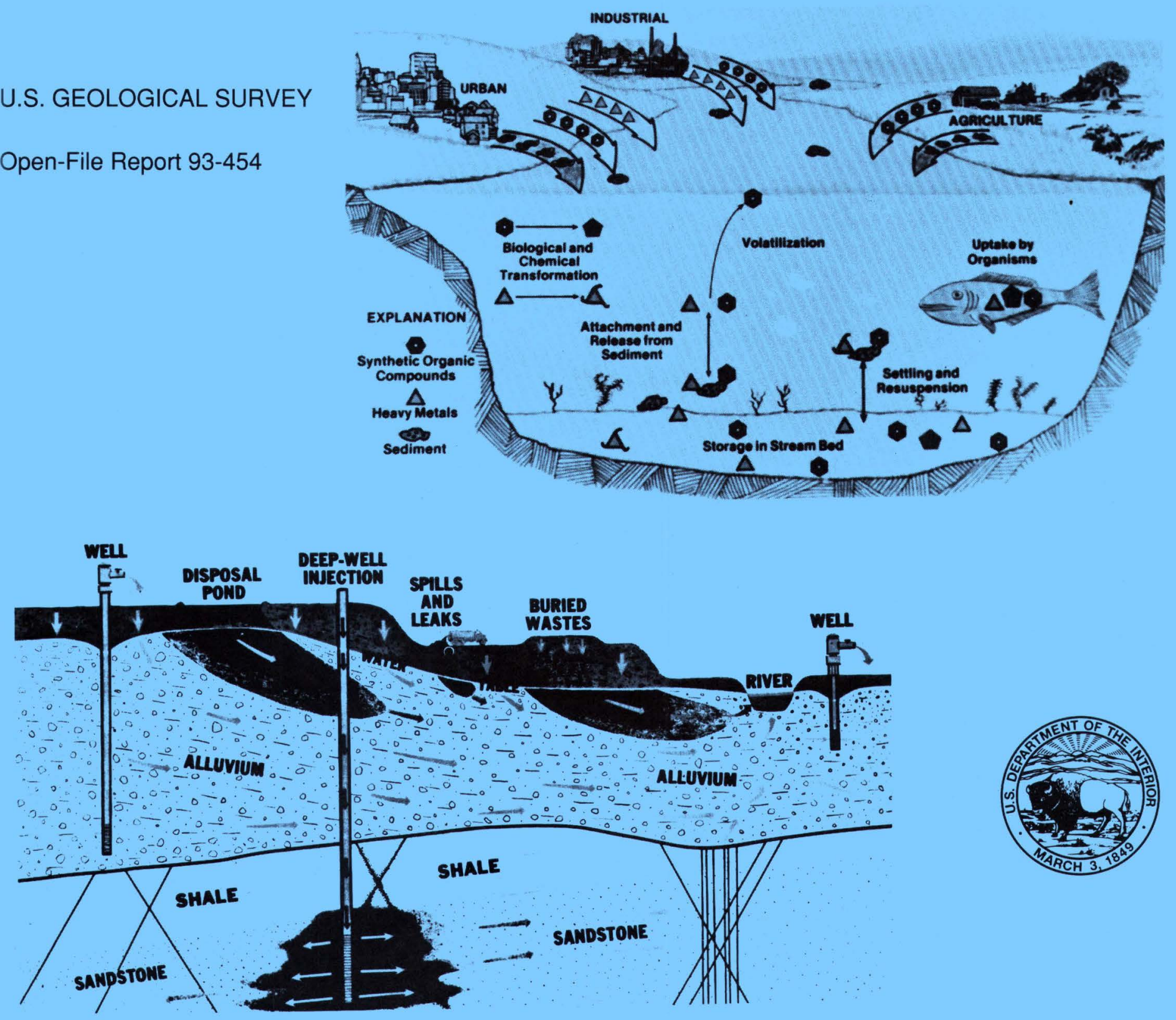


\section{U.S. Geological Survey}

Toxic Substances Hydrology Program-Abstracts of the Technical Meeting,

Colorado Springs, Colorado,

September 20-24, 1993

By David W. Morganwalp and David A. Aronson, Compilers U.S. GEOLOGICAL SURVEY

Open-File Report 93-454 
U.S. DEPARTMENT OF THE INTERIOR

BRUCE BABBITT, Secretary

U.S. GEOLOGICAL SURVEY

Robert M. Hirsch, Acting Director

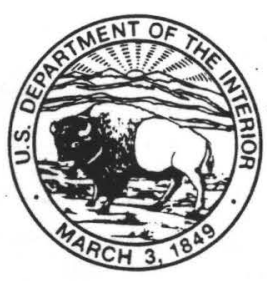

For additional information write to:

Assistant Coordinator

Toxic Substances Hydrology Program

U.S. Geological Survey

412 National Center

Reston, Virginia 22092
Copies of this report can be purchased from:

U.S. Geological Survey Earth Science Information Center Open-File Reports Section, MS-517 Box 25286, Denver Federal Center Denver, Colorado 80225 


\section{PREFACE}

The U.S. Geological Survey's Toxic Substances Hydrology Program provides earth-science information needed to understand the movement and fate of toxic substances in the Nation's ground and surface water. Research activities conducted under the auspices of the program include: (1) the investigation of the physical, chemical, and biological processes that control contaminant transport and fate in ground and surface water at field sites and in the laboratory; (2) the development of new analytical methods and sampling techniques; and (3) the investigation of the relations among various human activities, environmental characteristics, and regional patterns of water quality.

The latest results of research conducted under the Toxic Substances Hydrology Program were presented at a technical meeting held in Colorado Springs, Colorado, in September 1993. This report contains the abstracts of oral and poster presentations given at the meeting. The chapters in this report correspond to the meeting's sessions. Oral and poster presentations in each session focused on research at a specific field site or topical subject. To ensure the availability of the abstracts at the meeting, the abstracts were reproduced as submitted by the authors. Consequently, the abstracts are not published in a uniform format.
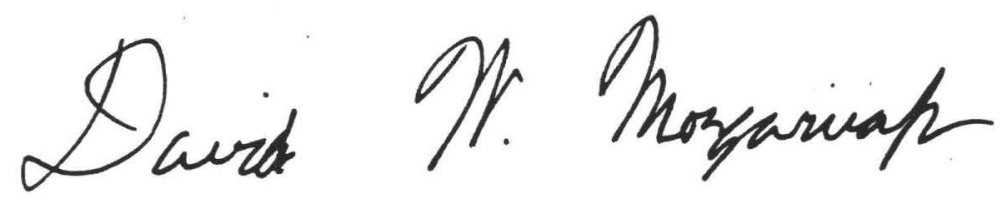

David W. Morganwalp, Assistant Coordinator

Toxic Substances Hydrology Program 


\section{CONTENTS}

\section{Session 1--Galloway}

Overview of research on the transport, microbial degradation, and remediation of hydrocarbons at a subsurface gasoline-spill site in Galloway Township, New Jersey, by Arthur L. Baehr and Jeffrey M. Fischer.

Biogeochemical fate of organic acid metabolites produced during the microbial degradation of hydrocarbons in ground water, by Isabelle M. Cozzarelli and Mary Jo Baedecker.

Method for estimating the rate of microbial degradation of hydrocarbons associated with bioventing at a gasoline-spill site in Galloway Township, New Jersey, by Matthew A. Lahvis, Arthur L. Baehr, and Jeffrey M. Fischer.

Optimizing the design of vapor-extraction remediation systems for removal of organic contaminants from the unsaturated zone, by Claire Welty, Craig J. $\underline{\text { Joss, }}$, and Arthur L. Baehr.

\section{Session 2--Mirror Lake}

Overview of research on use of hydrologic, geophysical, and geochemical methods to characterize flow and solute transport in fractured rock at the Mirror Lake site, New Hampshire, by Allen M. Shapiro and Paul A. $\underline{\text { Hsieh. }}$.

Fracture detection in crystalline rocks, Mirror Lake area, Grafton County, New Hampshire, by F. Peter Haeni, John W. Lane Jr., Christopher C. Barton, and David L. Lieblich

Electromagnetic and seismic tomography compared to borehole acoustic televiewer and flowmeter logs for subsurface fracture mapping at the Mirror Lake site, New Hampshire, by David L. Wright, Gary R. Olhoeft, Paul A. Hsiesh, Ernest L. Majer, Frederick L. Paillet, and John W. Lane, Jr.

Hydraulic characteristics of fractured bedrock underlying the FSE well field at the Mirror Lake site, Grafton County, New Hampshire, by Paul A. $\underline{\text { Hsieh }}$ and Allen M. $\underline{\text { Shapiro }}$

Observational, experimental and inferred evidence for solute diffusion in fractured granite aquifers: Examples from the Mirror Lake Watershed, Grafton County, New Hampshire, by Warren W. Wood, Allen M. $\underline{\text { Shapiro, }}$, and Paul A. $\underline{\text { Hsieh }}$

\section{Session 3--Cape Cod}

Overview of research at the Cape Cod site: Field and laboratory studies of physical, chemical, and microbiological processes affecting transport in a sewage-contaminated sand and gravel aquifer, by Denis R. LeBlanc.

Flow and solute transport during infiltration experiments in unsaturated sand and gravel, Cape Cod, Massachusetts, by David L. Rudolph, R. Gary Kachanoski, Michael A. Celia, and Denis R. LeBlanc.

An experiment to quantify temporal variability of water samples obtained from screened wells, by Thomas E. Reilly and Denis R. LeBlanc.

The transport of inorganic contaminants from a sewage plume in the Cape Cod aquifer, Massachusetts, by Brigid A. Rea, Douglas B. Kent, Linda C.D. Anderson, James A. Davis, and Denis R. LeBlanc.

Evaluation of geochemical indicators of metal adsorption in a sand and gravel aquifer, Cape Cod, Massachusetts, by Christopher C. Fuller, Jennifer A. Coston, James A. Davis, and Elizabeth A. Dixon

Small-scale tracer tests applied to the measurement of in-situ denitrification rates in a sewage-contaminated aquifer, Cape Cod, Massachusetts, by Myron H. Brooks,

Richard L. Smith, and Stephen P. Garabedian. 


\section{Galloway}

Use of column studies and a reactive transport model to measure biodegradation rates of hydrocarbons in unsaturated porous media, by Ronald J. Baker and Arthur L. Baehr ..

Hydrogeology, contaminant distribution, and biodegradation processes at a gasoline-spill research site in Galloway Township, New Jersey, by Jeffrey M. Fischer, Nicholas P. Smith, and Arthur L. Baehr.

Determination of vapor-phase diffusion coefficients for unsaturated-zone sediments at a gasoline-spill site in Galloway Township, New Jersey, by Jeffrey M. Fischer,

Ronald J. Baker, Matthew A. Lahvis, and Arthur L. Baehr.

A multispecies transport model to simulate vapor extraction and bioventing remediation of unsaturated zones contaminated with gasoline, by Craig J. Joss and Arthur L. Baehr

Method for monitoring biodegradation of hydrocarbons and hydrocarbon in microbial in unsaturated porous media, by John G. Nolan, Ronald J. Baker, and Arthur L. Baehr.

A comparison of two analytical techniques for identifying and measuring the concentrations of volatile hydrocarbons in ground-water, by Curtis S. Phinney and Isabelle M. Cozzarelli.

Mirror Lake

Characterizing bedrock fractures in outcrop for studies of ground-water hydrology: An example from Mirror Lake, Grafton County, New Hampshire, by Christopher C. Barton...

Use of a borehole color video camera to identify lithologies, fractures, and borehole conditions in bedrock wells in the Mirror Lake area, Grafton County, New Hampshire, by Carole D. Johnson...........

Velocity, attenuation, and dispersion electromagnetic tomography in fractured rock, by David L. Wright, Gary R. Olhoeft, and Thomas P. Grover.

Use of well logs to prepare the way for packer strings and tracer tests: Lessons from the Mirror Lake study, by Frederick L. Paillet.

Field instrumentation for multilevel monitoring of hydraulic head in fractured bedrock at the

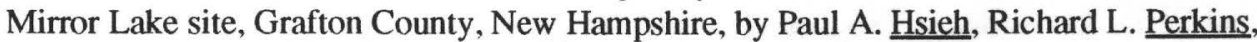
and Donald $\mathrm{O}$. Rosenberry

A new method of performing controlled injection of traced fluid in fractured crystalline rock, by Allen M. Shapiro and Paul A. Hsieh

A conceptual model for estimating regional ground-water velocity in bedrock of the Mirror Lake area, Grafton County, New Hampshire, by Allen M. Shapiro, Warren W. Wood, Eurybiades Busenberg, Stefan Drenkard, L.Neil Plummer, Thomas Torgersen, and Peter $\underline{\text { Schlosser. }}$

Helium isotope analysis and tritium-helium age dating in the Mirror Lake basin, Grafton County, New Hampshire, by Stefan Drenkard, Thomas Torgersen, Ralf Weppernig, Kennth Farley,

Peter Schlosser, Robert L. Michel, Allen M. Shapiro, and Warren W. Wood

Concentrations of chlorofluorocarbons and other gasses in ground water at Mirror lake, New Hampshire, by Eurybiades Busenberg, and L. Neil Plummer

Factors affecting recharge to crystalline rock in the Mirror Lake Area, Grafton County, New Hampshire, by Philip T. Harte and Thomas C. Winter

\section{Cape Cod}

Numerical simulation of downward movement of solutes during a natural-gradient tracer test in sand and gravel, Cape Cod, Massachusetts, by Denis R. LeBlanc and Michael A. Celia.

Heavy-metal transport in a sand and gravel aquifer under variable chemical conditions, Cape Cod, Massachusetts, by James A. Davis, Douglas K. Kent, Jennifer A. Coston, and Kathryn M. Hess...........

Spatial variability of metal-ion adsorption and hydraulic conductivity in a sand and gravel aquifer, Cape Cod, Massachusetts, by Kathryn M. ess, James A. Davis, Christopher C. Fuller, and Jennifer A. Coston 
Preliminary type-curve analysis of an aquifer-test in an unconfined sand and gravel aquifer, Cape Cod,

Massachusetts, by Allen F. Moench, Denis R. LeBlanc, and Stephen P. Garabedian

Effects of changes in aquifer properties on simulated fluid-particle pathlines, Cape Cod,

Massachusetts, by John P. Masterson and Donald A. Walter.

Potential long-term effects of phosphate contamination in an alluvial aquifer, Cape Cod, Masssachusetts, by Kenneth G. Stollenwerk.

Background aqueous chemistry and effects of carbon dioxide variations in recharge in shallow ground water in a glacial outwash aquifer, by Roger W. Lee.

Overview of research on the distribution and role of protozoa in an organically contaminated aquifer at Cape Cod, Massachusetts, by Nancy E. Kinner and Ronald W. Harvey

Transport of indigenous protozoa in a sandy aquifer, Cape Cod, Massachusetts, by Ronald W. Harvey, Nancy E. Kinner, Daniel MacDonald, Amoret L. Bunn, and David W. Metge...

Use of static column experiments to identify factors affecting bacterial attachment in contaminated aquifer sediments from Cape Cod, Massachusetts, by David W. Metge, Ronald W. Harvey, George R. Aiken, and Larry B. Barber, II

\section{Session 5--Picatinny}

Overview of research activities on the transport and fate of chlorinated solvents in ground-water at Picaninny Arsenal, New Jersey, 1991-93, by Thomas E. Imbrigiotta and Mary Martin...

Simulation of transport, desorption, volatilization, and microbial degradation of trichloroethylene in ground water at Picatinny Arsenal, New Jersey, by Mary Martin

Simulation of trichloroethylene volatilization in the unsaturated zone during a field infiltration

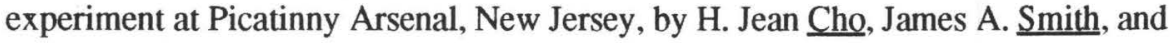
Peter R. Jaffe

Cometabolic biotransformation of trichloroethylene and cis- 1,2-dichloroethylene in unsaturated zone soil at Picatinny Arsenal, New Jersey, by Theodore A. Ehlke and Thomas E. Imbrigiotta.

\section{Session 6--Methods, Techniques, and Research on Agricultural Chemicals in the Midwest I}

Sampling borehole flow to quantify aquifer cross-contamination by volatile organic compounds, by Ronald A. Sloto.

Isolation of lipophilic organic contaminants along the Upper Mississippi River using a semipermeable membrane device, by Geoffrey S. Ellis and Colleen E. Rostad

A sample-freezing drive shoe for a wireline-piston core sampler, by Fred Murphy and William N. Herkelrath

Use of ${ }^{15} \mathrm{~N}$ to trace movement of nitrogen fertilizer at a field plot, by Dale W. Blevins,

Donald H. Wilkison, Steven R. Silva, and Brian Kelly

Effects of farming systems on ground-water quality at the Princeton, Minnesota, Management Systems Evaluation Area (MSEA), 1991, by Matthew K. Landon, Geoffrey N. Delin, John A. Lamb, Robert H. Dowdy, and James L. Anderson

\section{Session 7--Research on Agricultural Chemicals in the Midwest II}

Occurrence, deposition, and long-range transport of herbicides in percipitation in the midwestern and northeastern United States, by Donald A. Goolsby, E. Michael Thurman, Michael L. Pomes, Michael T. Meyer, and William A. Battaglin

Chemistry, degradation, and transport of triazine herbicide metabolites in surface water, by E. Michael Thurman, M.S. Mills, and Michael T. $\underline{\text { Meyer. }}$ 
Annual use and transport of agricultural chemicals in the Mississippi River, 1991-92,

by William A. Battaglin, Donald A. Goolsby, and Richard H. Coupe

Pesticides in near-surface aquifers: Results of the midcontinental United States ground-water reconnaissance, 1991-92, by Dana W. Kolpin. Donald A. Goolsby, Diana S. Aga, Jana L. Iverson, and E. Michael Thurman

Comparison of simulated and observed movement of bank-storage water adjacent to the Cedar River, Iowa, by Paul J. Squillace and David W. Pollock.

Determining the relative age, transport, and three-dimensional distribution of atrazine in a reservoir using immunoassay, by James D. Fallon.and E. Michael Thurman.

\section{Session 8--Poster Presentations}

\section{Picatinny}

Desorption of trichloroethylene from aquifer sediments at Picatinny Arsenal, New Jersey, by David Koller, Thomas E. Imbrigiotta, Arthur L. Baehr, and James A. Smith

Effect of air drying on solvent extraction of trichloroethylene-contaminated sediments at Picatinny Arsenal, New Jersey, by David Koller, Thomas E. Imbrigiotta, and James A. Smith

In situ anaerobic biotransformation of trichloroethylene and cis-1,2-dichloroethylene in aquifer sediments from Picatinny Arsenal, New Jersey, by Theodore A. Ehlke, Barbara H. Wilson, John T. Wilson and Thomas E. Imbrigiotta,

Surfactant-enhanced remediation of ground water at Picatinny Arsenal, New Jersey, by James A. Smith and James J. Deitsch.

\section{Methods and Techniques}

Determination of surface area of soil components by sorption of nitrogen and ethylene glycol monoethyl ether vapors and evaluation of adsorption, partition and cation solvation processes, by Cary T. Chiou and David W. Rutherford.

Measurement of concentrations of alachlor and its ethanesulfonic acid metabolite in water by solid-phase extraction and enzyme-linked immunosorbent assay, by Diana S. Aga, E. Michael Thurman, and Michael L. Pomes.

Isocratic separation of alachlor ethanesulfonic acid, alachlor oxoacetic acid, and hydroxyatrazine by reversed-phase liquid chromatography, by Michael L. Pomes, Douglas F. Holub, Dana S. Aga, and E. Michael Thurman

\section{Research on Agricultural Chemicals in the Midwest}

Atrazine transport and degradation in a pristine watershed: The fate of atrazine deposited by precipitation, by Aron E. Cromwell and E. Michael Thurman

Persistance of herbicides in selected reservoirs in the midwestern United States: Some preliminary results, by Donald A. Goolsby, William A. Battaglin, James D. Fallon, Diana S. $\underline{\text { Aga, }}$ Dana W. Kolpin, and E.Michael Thurman

Reconnaissance data for selected herbicides and two metabolites in surface water of the midwestern United States: Chemical analysis by immunoassay and gas chromatography/mass spectrometry, by Elizabeth A. Scribner, E. Michael Thurman, and Donald A. Goolsby.

Relation of nitrate concentrations in surface water to land use in the upper midwestern United States, $1989-90$, by Dave K. Mueller, Barbara C. $\underline{\text { Ruddy, }}$, and William A. Battaglin.

Transport and concentrations of selected herbicides and nitrate in the Sangamon River, Illinois, April 1991 - March 1992, by G.P. Johnson and R.H. Coupe

The degradation and transport of cyanazine metabolites in surface water of the midwestern United States, by Michael T. Meyer and E. Michael Thurman. 
Temporal distributions of herbicide and nitrite-nitrate concentrations and loads in the West Fork of Big Blue River, Nebraska, 1990 and 1991-92, by A. Douglas Druliner, Donald A. Goolsby, and Michael T. Meyer

Prediction of nitrate-nitrogen and atrazine contamination in the high plains aquifer in Nebraska, by A. Douglas Druliner and Tim S. McGrath

Fate of alachlor, atrazine, and bromide in a corn plot near Topeka, Kansas, by David A. Eckhardt,

R.J. Wagenet, E. Michael Thurman, and P.L. Barnes

Effects of topography on the transport of agricultural chemicals near Princeton, Minnesota, 1992, by Geoffrey N. Delin, and Matthew K. Landon.

Spatial variability of unsaturated-zone properties in relation to topography in a sand-plain setting near Princeton, Minnesota, by Geoffrey N. Delin, Matthew K. Landon, Richard W. Healy, and Harold W. Olson.

Geochemistry of nitrogen in a farmed watershed near Princeton, Minnesota, by Richard B. Wanty,

Michele L. Tuttle, Matthew K. Landon, Geoffery N. Delin, and J.K. Böhlke.

Nitrogen uptake and soil water variability across a sand plain landscape, by John A. Lamb, M.D. Tomer, J.L. Anderson, and Robert H. Dowdy.....

Geophysical investigations of heterogeneity and scale at the Princeton, Minnesota, Management Systems Evaluation Area, by Jeffrey E. Lucius, and Gary R. Olhoeft

Chemical loads of nitrate, atrazine, and metolachlor in the Walnut Creek watershed near Ames, Iowa, 1991-92, by P.J. Soenksen, J.L. Hatfield, and D.J. Schmitz.

Atrazine transport through preferential pathways at the Missouri Management System Evaluation Area, by James A. Tindall and William K. Vencill

\section{Unsaturated Zone Research}

Measurements of hydraulic conductivity and capillary pressure under unsaturated conditions in a laboratory triaxial system, by Harold W. Olsen.

Unsaturated zone properties at a hazardous-waste-disposal site at the Idaho National Engineering Laboratory, by Stephanie Shakofsky and John R. Nimmo

\section{Session 9--Bemidji}

Evolution of the contaminant plume in an aquifer contaminated with crude oil, Bemidji Minnesota, by Mary Jo Baedecker, Isabelle M.,_cozzarelli, Philip C. Bennett, Robert P. Eganhouse, and Marc F. Hult,

Use of simulation to study field-scale solute transport and biodegradation at the Bemidji Minnesota, crude-oil spill site, by Hedeff I. Essaid, Mary Jo Baedecker, and Isabelle M. Cozzarelli...

Source mass balance calculated from changes in composition of spilled crude oil in the subsurface near Bemidji, Minnesota, by Matthew K. Landon and Marc F. Hult,

\section{Session 10--San Francisco Bay}

Challenges in detecting effective contaminants on an estuarine ecosystem influenced by many disturbances:

San Francisco Bay, by Samuel N. Luoma, and Frederic H. Nichols, and Cynthia Brown...

Diazinon concentrations and transport in the Sacramento River and San Francisco Bay, California,

February 1993, by Kathryn M. Kuivila and Dwight D. Copeland...

Hydrodynamics of California's Sacramento-San Joaquin Delta, and the collection of flow data for tracking of pesticides, by Richard N. Oltmann . 
Concentrations of dissolved rice pesticides in the Colusa Basin Drain and Sacramento River,

California, 1990-92, by Kathryn L. Crepeau, Kathryn M. Kuivila, and Joseph Domagalski

A survey of molecular marker compounds in sediments of San Francisco Bay, California,

by Frances D. Hostettler, John B. Papp, Wilfred E. Pereira, and Keith A. Kvenvolden.

\section{Session 11--Upper Arkansas River}

Past and present research on metal transport in St. Kevin Gulch, Colorado, by Briant A. Kimball

Iron and zinc budgets in surface water for a natural wetland affected by acidic mine drainage,

St. Kevin Gulch, Lake County, Colorado, by Katherine Walton-Day

Tracer injections in small streams--why and how we do them, by Gary W. Zellweger

Processes controlling dissolved copper concentrations during an instream $\mathrm{pH}$-modification experiment, by Kathleen S. Smith.

An equilibrium-based simulation model for reactive solute transport in small streams, by Robert L. Runkel, Kenneth E. Bencala, and Robert E. Broshears .

Simulation of reactive transport during a pH- modification experiment in a mountain stream affected by acidic mine drainage, by Robert E. Broshears, Briant A. Kimball, and Robert L. $\underline{\text { Runkel }}$

\section{Session 12--Poster Presentations}

Bemidji

Multiphase-flow modeling at the Bemidji, Minnesota, crude-oil spill site with geostatistical simulation of hydraulic properties, by Leslie A. Dillard, Hedeff I. Essaid, and

William N. Herkelrath

Studies of the molecular size of dissolved organic carbon fractions downgradient from the oil body at Bemidji, Mimmesota, by George Aiken,

Small-scale chemical heterogeneities in a crude-oil-contaminated aquifer, Bemidji, Minnesota, by Isabelle M. Cozzarelli, Mary Jo Baedecker, George $\underline{\text { Aiken, and Curtis Phinney. }}$

Use of carbon and hydrogen stable isotopes to investigate the production and fate of methane at a toxic waste site, Bemidji, Minnesota, by Kinga Revesz, Tyler Coplen, Mary Jo Baedecker, and Marc Hult

Sorption of polycyclic aromatic hydrocarbons to aquifer materials containing a low-organic carbon content from Bemidji, Minnesota, by Joseph J. Piatt, Steven J. Eisenreich, Debera A. Backhus, and Paul D. Capel

\section{Fate of Hydrocarbons in the Environment}

Effects of $\mathrm{Pb}$ and terminal-electron-accepting processes on organic acid concentrations in contaminated aquifer sediments, by Paul M. Bradley, Francis H. Chapelle, and Don A. Vroblesky.......

Shifting of terminal-electron-accepting processes in a petroleum-hydrocarbon-contaminated aquifer, by Don A. Vroblesky and Francis H. Chapelle

Modeling steady-state methanogenic degradataion of phenols in ground water at Pensacola, Florida, by Barabara A. Bekins, E. Michael Godsy, and Donald F. Goerlitz

Modeling breakthrough of nitrogen heterocyclic compounds in laboratory columns containing creosote contaminated aquifer material, by Ean Warren and E. Michael Godsy

Preliminary assessment of jet fuel contamination in an atoll aquifer, by Gordon W. Tribble,

Roger W. Lee, Duane S. Wydoski, Jill D. Torikai, and Charles D. Hunt, Jr. 


\section{San Francisco Bay}

Distribution and possible biological effects of diazinon in the San Joaquin River and Sacramento-San Joaquin Delta, California, February 1993, by Kathryn M. Kuivila, Robert C. Sheipline, and Christopher G. Foe

Method for estimating the activity of carbofuran-degrading microorganisms in environmental samples, by William J. Meyers and Kathyrn M. Kuivila

Distributions of organochlorine compounds in sediments and livers of striped bass (morone saxatilis) in San Francisco Bay-Delta Estuary, by Wilfred E. Pereira, Frances D. Hostettler, John R. Cashman, and Richard S. Nishioka.

Distributions and benthic flux of dissolved sulfides in the oxic water column of San Francisco Bay,

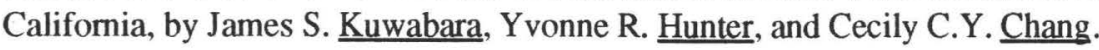

\section{Fate of Organic Contaminants in Surface Water}

Organic carbon associated with suspended silt and colloid from the Mississippi River and some of its tributaries, July 1991-May 1992, by Colleen E. Rostad, Stephanie G. Monsterleet,

LaDonna M. Bishop, and Geoffrey S. Ellis

Linear alkylbenzene sulfonate in the Mississippi River, by Charles F. Tabor, Jr., and Larry B. Barber, II

Accumulation of organochlorine compounds in Hydrilla verticillata relative to sediments in the tidal Potomac River, by Jessica A. Hopple and Gregory D. Foster

\section{Upper Arkansas River}

Difficulties with intermediate-scale experiments for studies of iron chemistry in streams affected by acid mine drainage, by Diane M. McKnight, Kenneth E. Bencala, Richard A. Harnish, and Robert L. Runkel

Metal concentrations of sedges collected on the wetland receiving acid mine drainage from St. Kevin Gulch, Leadville, Colorado, by B.M. Erickson, P.H. Briggs, and T.R. Peacock.

Uraniferous waters of southeastern Colorado: A function of geology, climate, and land use, by Robert A. Zielinski and Sigrid $\underline{\text { Asher-Bolinder. }}$

\section{Session 13--Additional Research on Toxic Substances}

Effects of organic contaminants in municipal and industrial wastewaters on the quality of water and streambed sediments in the Mississippi River, by Larry B. Barber, II, Jerry A. Leenheer, Wilfred E. Pereira, and Mary A. Noriega

Bioremediation of petroleum and metal contamination with dissimilatory metal reduction, by Derek R. Lovley.

Pathways of methanogenic biodegradation of creosote-derived aromatic compounds, by E. Michael Godsy, Donald F. Goerlitz, and Dunja Grbic-Galic....

Reaction of arsenic minerals and gold ores with alkaline cyanide solutions, by Walter H. Ficklin, Geoffrey S. Plumlee, and John B. McHugh

\section{Session 14--Plains and Nonpoint Source Contamination}

Fate and transport of atrazine at the Plains, Georgia, ground-water study site, by Ralph A. Leonard, L.R. Marti, David W. Hicks, and James B. McConnell

Unsaturated zone transport at the Plains, Georgia, field site, by David D. Bosch, Ralph A. Leonard, and Robert K. Hubbard 
Two-dimensional distribution of a bromide tracer in the unsaturated zone at the Plains, Georgia, research site, by David W. Hicks, James B. McConnell, H.H. Persinger, Judith D. Scholz, and Robert K. Hubbard.

Modeling statistical relations between shallow ground-water quality, human activities, land use, and thickness of the unsaturated zone on Long Island, New York, by Paul E. Stackelberg and

David A.V. Eckhardt

Use of flowpath simulation to determine contributing areas and travel times of nonpoint-source ground-water contamination, Gloucester County, New Jersey, by Anthony S. Navoy

\section{Session 15--Pinal Creek}

Hydrologic and geochemical factors affecting metal-contaminant transport in Pinal Creek Basin near Globe, Arizona, by James G. Brown and Judson W. Harvey

Unsaturated zone diffusion of carbon dioxide and oxygen in the Pinal Creek basin, Arizona, by Pierre D. Glynn and Eurybiades Busenberg.

Chemical processes in manganese oxide and carbonate precipitation in Pinal Creek, Arizona, by John D. Hem and Carol J. Lind

Interactions between shallow ground water and surface water that affect metal transport in Pinal Creek, Arizona, by Judson W. Harvey, Christopher C. Fuller, and Brian J. Wagner

\section{Session 16--Poster Presentations}

\section{Additional Research on Toxic Substances}

Anaerobic growth of bacterial strain SES3 with selenate as the electron acceptor, by Jodi Switzer Blum, Charles W. Culbertson, and Ronald S. Oremland

Microbial degradation of nitrotoluenes in surface soils and aquifer sediments, Weldon Spring, Missouri, by Francis H. Chapelle and Paul M. Bradley

Chemical, isotopic, and microbiological evidence for denitrification during transport of domestic wastewater through a thick unsaturated zone in the Mojave Desert, by Roy A. $\underline{\text { Schroeder, }}$ Peter Martin, and J.K. Böhlke

Potential anhydrite precipitation associated with deep injection of ground-water brine from Paradox Valley, Colorado, by Yousif K. Kharaka, William C. Evans, Gil Ambats, and James J. Thordsen

Apparent solute dispersion in an alluvial-aquifer/stream, by J. Jeffrey $\underline{\text { Starn }}$

Depletion of nitrogen-bearing explosives wastes in a shallow ground-water plume near Hawthorne, Nevada, by Albert S. Van Denburgh, Donald F. Goerlitz, and E. Michael Godsy.

\section{Plains and Nonpoint Source Contamination}

Spatial variability of soil properties affecting chemical transport at the Plains, Georgia, Research Site, by Robert K. Hubbard, David D. Bosch, Ralph A. Leonard, and David W. Hicks

A review of methods for assessing the potential for regional ground-water contamination, by David R. Soller

Evaluating the effect of land use and sampling depth on ground-water quality, Long Island, New York, by Paul E. Stackelberg.

Vulnerability of water from public supply wells to contamination by pesticides, Potomac-RaritanMagothy aquifer system, New Jersey coastal plain, by E.F. Vowinkel 


\section{Pinal Creek}

Dissolved gas and chlorofluorocarbon content of ground waters in the Pinal Creek Basin, Arizona, by Pierre D. Glynn and Eurybiades Busenberg.

Experimental studies of trace-metal partitioning in perennial reaches of Pinal Creek, Arizona, by Chrisopher C. Fuller

Association of selected metals with colloidal and suspended particulate material in shallow ground water and surface water at Pinal Creek, Arizona, by Judson W. Harvey and Christopher C. Fuller.

Solute transport parameter estimation for an injection experiment at Pinal Creek, Arizona, by Brian J. Wagner and Judson W. Harvey

Alteration of alluvium by acidic ground water resulting from copper mining at Pinal Creek, Arizona, by Carol J. Lind and Kenneth G. Stollenwerk

Relations among algal species and chemical gradients in Pinal Creek, Arizona, by Patrice H. Spindler and Milton R. Sommerfeld 

Session 1--Galloway 


\title{
OVERVIEW OF RESEARCH ON THE \\ TRANSPORT, MICROBIAL DEGRADATION, AND REMEDIATION OF HYDROCARBONS AT A SUBSURFACE GASOLINE-SPILL SITE IN GALLOWAY TOWNSHIP, NEW JERSEY
}

by

\author{
Arthur L. Baehr ${ }^{1)}$ and Jeffrey M. Fischer ${ }^{1)}$
}

\begin{abstract}
Since 1988, the U.S. Geological Survey has conducted research on the fate and transport of hydrocarbons at a site of subsurface gasoline contamination in Galloway Township, New Jersey. Work has focused on three interrelated areas of research: ground-water contaminant geochemistry, estimation of microbial degradation rates of hydrocarbons on the basis of rates of gas transport in the unsaturated zone, and vapor-extraction remediation design.

Contaminant-geochemistry work has produced a water-quality data base that indicates zones of aerobic degradation adjacent to zones of anaerobic degradation with sharp chemicalconcentration gradients in narrow interfacial zones. The analysis of gas transport in the unsaturated zone has provided a method for quantifying rates of aerobic hydrocarbon biodegradation in the capillary zone and shallow ground water. Mathematical models have been developed to simulate vapor-extraction remediation and to optimize system design. Research activity in each area is detailed and the project bibliography is updated.
\end{abstract}

1) U.S. Geological Survey, New Jersey District, West Trenton, New Jersey 


\title{
BIOGEOCHEMICAL FATE OF ORGANIC ACID METABOLITES PRODUCED DURING THE MICROBIAL DEGRADATION OF HYDROCARBONS IN GROUND WATER
}

\author{
By Isabelle M. Cozzarelli ${ }^{1}$ and Mary Jo Baedecker ${ }^{1}$
}

\begin{abstract}
A combined field and laboratory study of low-molecular-weight organic acids was undertaken to improve an understanding of their distribution and the geochemical parameters that influence the prevalence of these compounds in ground water of a shallow aquifer contaminated with gasoline, in Galloway Township, New Jersey. The degradation of aromatic hydrocarbons from gasoline occurred in situ by oxidation-reduction reactions mediated by bacteria. The important reactions were aerobic degradation and reduction of nitrate, sulfate, and Fe(III). Temporal and spatial shif ts in the biogeochemical reactions occurred in response to changes in hydrogeochemical conditions in the aquifer.

Low-molecular-weight aliphatic, aromatic, and alicyclic organic acids were associated with hydrocarbon degradation in oxygen-depleted zones of the aquifer. Laboratory microcosm experiments demonstrated that the biogeochemical fate of specific organic acids observed in ground water varied with the structure of the acid and the availability of electron acceptors. Benzoic and phenylacetic acid were degraded by the indigenous aquifer microorganisms when nitrate was supplied as an electron acceptor. Aromatic acids with two or more substituents on the benzene ring persisted under nitratereducing conditions. Organic acids produced during hydrocarbon degradation participate in processes such as metal complexation, sorption, and mineral dissolution; thus, understanding the biogeochemical fate of organic acids is essential to predicting the geochemical evolution of shallow aquifers containing degradable organic compounds.
\end{abstract}

\footnotetext{
${ }^{1}$ U.S. Geological Survey, 12201 Sunrise Valley Drive, MS 431, Reston, Virginia 22092
} 
METHOD FOR ESTIMATING THE RATE OF MICROBIAL DEGRADATION OF

HYDROCARBONS ASSOCIATED WITH BIOVENTING AT A

GASOLINE-SPILL SITE IN GALLOWAY TOWNSHIP, NEW JERSEY

Matthew A. Lahvis ${ }^{1}$, Arthur L. Baehr ${ }^{1}$, and Jeffrey M. Fischer ${ }^{1}$

\section{ABSTRACT}

Bioventing is the enhancement of microbial degradation caused by the delivery of atmospheric oxygen to aerobically biodegradable contaminants in the subsurface through vapor-extraction remediation. Simulation of the redistribution of oxygen and carbon dioxide in the unsaturated zone following a period of vapor extraction provides a method for estimating the rate of microbial degradation of hydrocarbons. Rebound vapor-concentration data are used to calibrate a diffusive-transport model developed to quantify gas fluxes and the degradation rate. The resulting rates are indicative of the upper limit of aerobic degradation that can occur during or immediately after vapor extraction, when oxygen availability exceeds microbial utilization. Microbial degradation is a significant hydrocarbon fate at a gasoline-spill site in Galloway Township, New Jersey.

${ }^{1}$ U.S. Geological Survey, 810 Bear Tavern Road, West Trenton, New Jersey 08628 
OPTIMIZING THE DESIGN OF VAPOR-EXTRACTION REMEDIATION SYSTEMS FOR REMOVAL OF ORGANIC CONTAMINANTS FROM THE UNSATURATED ZONE By Claire Welty ${ }^{1}$, Craig J. Joss ${ }^{1}$, and Arthur L. Baehr ${ }^{2}$

\section{ABSTRACT}

A new mathematical model has been developed that can be used in the design of vapor-extraction and bioventing systems for removing organic contaminants from the unsaturated zone. The model has two major components: a three-dimensional finite-difference model of air flow in unsaturated porous media (AIR3D), and an algorithm that couples the three-dimensional air-flow model with mathematical programming (OPTAIR).

AIR3D is based on the flow of an ideal gas in porous media. The code consists of a preprocessor and postprocessor to be used with the U.S. Geological Survey ground-water flow simulator MODFLOW to solve the conservation-of-mass equation for air flow in a discretized three-dimensional domain. OPTAIR couples AIR3D with an optimization algorithm, to allow a user to determine the optimal number and arrangement of well screens and rates of air withdrawal or injection in the domain to obtain the most efficient design.

\footnotetext{
${ }^{1}$ Drexel University, Department of Civil and Architectural Engineering, Philadelphia, Pa. 19104

${ }^{2}$ U.S. Geological Survey, 810 Bear Tavern Road, West Trenton, N.J. 08628
} 
Session 2--Mirror Lake 


\title{
OVERVIEW OF RESEARCH ON USE OF HYDROLOGIC, GEOPHYSICAL,AND GEOCHEMICAL METHODS TO CHARACTERIZE FLOW AND CHEMICAL TRANSPORT IN FRACTURED ROCK AT THE MIRROR LAKE SITE, NEW HAMPSHIRE
}

\author{
Allen M. Shapiro ${ }^{1}$ and Paul A. Hsieh ${ }^{2}$
}

Research efforts at the Mirror Lake Toxic-Substances Hydrology Program research site in Grafton County, New Hampshire have focused on the development of equipment, field testing procedures, and interdisciplinary interpretive approaches of characterizing fluid movement and chemical transport in fractured rock over distances that range from tens of meters to kilometers. This paper summarizes the results of current research in bedrock hydrogeology in local- and regional-scale investigations at the Mirror Lake site. Local-scale investigations are conducted over distances of tens of meters and focus on identifyication of (1) fractures and fracture properties on exposed surfaces, (2) fractures in the subsurface using borehole and surface geophysics, and (3) hydraulic and transport properties of fractures by means of hydrologic testing. In regional-scale investigations, controlled hydrologic testing can not be conducted to identify hydraulic and transport properties of the bedrock. Regional-scale investigations have focused on (1) methods of collecting hydrologic and geochemical information in heterogeneous bedrock environments, and (2) interdisciplinary methods of synthesizing these data by ground-waterflow and chemical-transport modeling to infer hydraulic and transport properties of the bedrock.

1U.S. Geological Survey, Reston, VA

2U.S. Geological Survey, Menlo Park, CA 


\title{
FRACTURE DETECTION IN CRYSTALLINE ROCKS, MIRROR LAKE AREA, GRAFTON COUNTY, NEW HAMPSHIRE
}

\author{
by F.P. Haeni ${ }^{1}$, John W. Lane, Jr. ${ }^{1}$, C.C. Barton ${ }^{2}$, and David A. Lieblich ${ }^{1}$ \\ ${ }^{1}$ U.S. Geological Survey, Water Resources Division, Hartford, Connecticut \\ ${ }^{2}$ U.S. Geological Survey, Geologic Division, Denver, Colorado
}

\begin{abstract}
Six surface-geophysical methods were used to detect saturated fractures in the upper $60 \mathrm{~m}$ (meters) of bedrock at the U.S. Geological Survey's fractured-rock research site in the Mirror Lake area, Grafton County, New Hampshire. Crystalline bedrock, consisting of foliated schists intruded by granite, pegmatite, and gabbro, underlies 3 to $10 \mathrm{~m}$ of glacial drift throughout the study area. Surface-geophysical methods included azimuthal seismic refraction, azimuthal Schlumberger direct-current- (DC) resistivity, square-array DC-resistivity, inductive-terrain conductivity, very-low-frequency (VLF) terrain resistivity, and ground-penetrating radar (GPR).
\end{abstract}

Azimuthal seismic-refraction and DC-resistivity methods measured directionally dependent physical properties of the crystalline rock at the Camp Osceola well field and in a ballfield $75 \mathrm{~m}$ southeast of Mirror Lake. The interpretation of the seismic-refraction $\mathrm{P}$-wave data is that the primary fracture strike is $022.5^{\circ}$ (degrees) with a secondary strike at $127^{\circ}$. The orientation of the anisotropy and probably the fractures, as determined from a quantitative interpretation of the original P-wave data, is $037^{\circ}$. The interpretation of the DC-resistivity data is that the primary fracture strike is $030^{\circ}$ with a secondary strike at $150^{\circ}$. Inductive-terrain conductivity and VLF-terrain resistivity data show very small anomalies that have been interpreted as possible fractures or fracture zones having a strike of $045^{\circ}$. Processed GPR data were used to determine the depth to bedrock and to locate numerous subhorizontal reflectors, which are interpreted to be fractures, fracture zones, and (or) foliation in the bedrock.

The strike interpreted from the surface-geophysical data correlates with the strike determined from bedrock outcrops, which are located $150 \mathrm{~m}$ from the Camp Osceola well field along Interstate 93 . The outcrop data indicate a fracture-strike frequency maximum at $030^{\circ}$ and a secondary maximum at $000^{\circ}$. Fracture dips range from $20^{\circ}$ to $90^{\circ}$. 


\title{
Electromagnetic and Seismic Tomography Compared to Borehole Acoustic Televiewer and Flowmeter Logs for Subsurface Fracture Mapping at the Mirror Lake Site, New Hampshire
}

\author{
David L. Wright ${ }^{1}$, Gary R. Olhoeft ${ }^{1}$, Paul A. Hsieh ${ }^{2}$, Ernest L. Majer ${ }^{3}$, \\ Frederick L. Paillet ${ }^{1}$, and John W. Lane Jr. ${ }^{4}$
}

\begin{abstract}
Among the techniques used in research at the Mirror Lake site, Grafton County, New Hampshire, are electromagnetic (EM) and seismic tomography, borehole radar, borehole acoustic televiewer, and borehole flowmeter. Of these techniques, tomography and radar can probe several tens of meters between or around boreholes at that site with resolutions in the order of 1 meter, whereas televiewer data provides great detail at the borehole wall but little penetration. Flowmeter data, along with hydraulic tests and tracer tests provide information on hydraulic connectivity, but hydraulic paths between the wells can not be inferred from these data alone. We find from side-by-side comparison of electromagnetic and seismic tomograms of rock properties between wells FSE1 and FSE4 that both types of tomograms show the presence of fractures of high hydraulic transmissivity. We present velocity tomograms for two EM systems and one seismic system, attenuation tomograms for the two EM systems, and projections of fractures derived from acoustic televiewer logs. The pulsed transmitters used in the EM tomography at Mirror Lake produced wavelengths in the granite of about $2 \mathrm{~m}$. The seismic system produced wavelengths of about $1 \mathrm{~m}$. Seismic and EM tomography can detect the presence of fractures whose aperture is much smaller than a wavelength but can not resolve fractures whose spacing is much less than the wavelength. Resolution -the ability to distinguish two nearby objects from one another -- is determined by a number of factors, including spatial data density, but resolution usually can not be better than about half the wavelength used for probing regardless of whether the method is EM or seismic. It is possible to achieve some resolution improvement in low-attenuation environments, but a needed step to achieve maximum benefit from tomography is correlation of the tomograms with other hydrologic and geophysical information. Tomography is an art that is not fully mature but can be expected to improve in the future.
\end{abstract}

${ }^{1}$ U.S. Geological Survey, Denver, Colo.

${ }^{2}$ U.S. Geological Survey, Menlo Park, Calif.

${ }^{3}$ Lawrence Berkeley National Laboratory, Berkeley, Calif.

${ }^{4}$ U.S. Geological Survey, Hartford, Conn. 


\title{
HYDRAULIC CHARACTERISTICS OF FRACTURED BEDROCK \\ UNDERLYING THE FSE WELL FIELD AT THE MIRROR LAKE SITE, GRAFTON COUNTY, NEW HAMPSHIRE
}

\author{
By Paul A. Hsieh ${ }^{1}$ and Allen M. Shapiro ${ }^{2}$
}

\begin{abstract}
At the Mirror Lake site in Grafton County, New Hampshire, 13 wells are drilled in a 120$\mathrm{m}$ (meter) by 80 - $\mathrm{m}$ area, known as the FSE well field, to characterize the hydraulic and transport properties of the underlying fractured bedrock. Borehole geophysical logs and downhole video camera images show that each well intersects 20 to 60 fractures within the upper $60 \mathrm{~m}$ of bedrock. However, single-well hydraulic tests show that only one to three fractures in each well are highly transmissive. Multiple-well hydraulic tests suggest that the few highly transmissive fractures connect with one another locally to form fracture clusters. These highly transmissive fracture clusters are, in turn, connected to one another by fractures that are comparatively lower in transmissivity by several orders of magnitude. In such a fractured-bedrock setting, the response to a multiple-well hydraulic test is entirely different from the response in a homogeneous aquifer. These findings suggest that it is necessary to identify and characterize explicitly the highly transmissive fracture clusters in order to analyze multiple-well hydraulic tests at the FSE well field.
\end{abstract}

${ }^{1}$ U.S. Geological Survey, Menlo Park, CA
${ }^{2}$ U.S. Geological Survey, Reston, VA 
Observational, Experimental and Inferred Evidence for Solute Diffusion in Fractured Granite Aquifers: Examples from the Mirror Lake Watershed, Grafton County, New Hampshire

\author{
Warren W. Wood ${ }^{1}$, Allen M. Shapiro' ${ }^{1}$ and Paul A. Hsieh²
}

\begin{abstract}
The role of solute diffusion between ground water and granite in the Mirror Lake drainage area was evaluated by direct observation, experiment, and inference. The outcrops display ubiquitous Liesegang bands associated with fractures that clearly indicate the activity of diffusion in this system in the past. Laboratory experiments determined that the effective diffusion coefficient for ${ }^{137} \mathrm{Cs}$ was approximately $6 \times 10^{-13} \mathrm{~m}^{2} / \mathrm{s}$ in granite from Mirror Lake. The ${ }^{137} \mathrm{Cs}$ penetrated to a depth of approximately $7 \mathrm{~mm}$ in 101 days, demonstrating the potential for rapid diffusion in this system. Porosities of 32 granite samples averaged of 1.46 percent with a range of 1.07 to 2.32 percent. Measurements of carbon-isotope of ground water in the fractures suggest that calcite, identified in the granite, is dissolving and the bicarbonate generated is diffusing to the fractures; that is, a significant amount of the dissolved solids in the water in the fractures are derived from diffusion of weathering products from the rock matrix. These observations taken together are consistent with the interpretation that diffusion is a major process controlling solutes in this fractured granite aquifer.
\end{abstract}

1 U.S. Geological Survey, Reston, VA

2 U.S. Geological Survey, Menlo Park, CA 
Session 3--Cape Cod 


\title{
OVERVIEW OF RESEARCH AT THE CAPE COD SITE: FIELD AND LABORATORY STUDIES OF PHYSICAL, CHEMICAL, AND MICROBIOLOGICAL PROCESSES AFFECTING TRANSPORT IN A SEWAGE- CONTAMINATED SAND AND GRAVEL AQUIFER
}

\author{
by Denis R. LeBlanc ${ }^{1}$
}

The Cape Cod Toxic-Substances Hydrology research site in Falmouth, Massachusetts, is the focus for multidisciplinary field studies of the physical, chemical, and microbiological processes affecting transport in a sewage-contaminated sand and gravel aquifer. Past research has examined the distribution and fate of contaminants in a sewage plume that is more than 4 kilometers long and originates from the Otis Air Base wastewater-treatment facility. Current research is described in a synopsis of 15 papers. These papers describe efforts to characterize specific physical, chemical, and microbiological processes affecting transport and fate of solutes, bacteria, and protozoa at the site. These processes are characterized by use of laboratory experiments, such as batch and column tests; field experiments, such as natural-gradient tracer tests; and investigations of the sewage plume with specialized sampling methods. The results show the importance of physical and chemical heterogeneity, limited dispersion, and chemical processes at the sediment-water interfaces in determining the fate of contaminants in this aquifer.

\footnotetext{
${ }^{1}$ U.S. Geological Survey, Marlborough, MA
} 


\section{FLOW AND SOLUTE TRANSPORT DURING INFILTRATION EXPERIMENTS IN UNSATURATED SAND AND GRAVEL, CAPE COD, MASSACHUSETTS}

by David L. Rudolph ${ }^{1}$, R. Gary Kachanoski1 ${ }^{1,2}$, Michael A. Celia ${ }^{3}$, and Denis R. LeBlanc ${ }^{4}$

Flow and solute transport through the unsaturated zone were observed in detail during a series of infiltration experiments conducted in sand and gravel glacial outwash on Cape Cod, Massachusetts. The objectives of the experiments were to improve understanding of unsaturated-zone hydrology in heterogeneous sediments and to test the use of time-domain reflectometry (TDR) for measuring flow and transport in coarsegrained, unsaturated soils. Water content, water pressure, and solute concentration were measured during irrigation at several rates ( 7.9 to 37.0 centimeters per hour) on a test plot 2 meters wide and 10 meters long. Instrumentation was installed along the centerline of the test plot to a depth of 2 meters and included 168 TDR probes and 112 solution samplers/tensiometers. Sodium chloride was used as the tracer. At the conclusion of the infiltration experiments, the test plot was excavated to a depth of 2 meters to observe the stratigraphy directly. Data from the experiments were analyzed to quantify the spatial and temporal variability of water content and solute concentration under different infiltration rates. The effects of three-dimensional flow and solute transport laterally away from the instrumented transect were evident from a comparison of the applied and observed water and solute mass. The three-dimensional flow and spatial variability of water content and solute concentration are consistent with the spatial variability of the fine- and coarse-grained layers of sediment observed in the excavation after the experiments. The TDR method proved to be an efficient method for observing water content and solute transport in the permeable, coarse-grained sand and gravel.

\footnotetext{
${ }^{1}$ Waterloo Centre for Groundwater Research, Univ. of Waterloo, Waterloo, Ontario

2 Dept. of Land Resource Science, Univ. of Guelph, Guelph, Ontario

${ }^{3}$ Dept. of Civil Engineering and Operations Research, Princeton Univ., Princeton, NJ

${ }^{4}$ U.S. Geological Survey, Marlborough, MA
} 


\title{
AN EXPERIMENT TO QUANTIFY TEMPORAL VARIABILITY OF WATER SAMPLES OBTAINED FROM SCREENED WELLS
}

\author{
by Thomas E. Reilly ${ }^{1}$ and Denis R. LeBlanc ${ }^{2}$
}

The chemical composition of water sampled from some screened wells has been observed to exhibit sustained temporal variability. Results from a field experiment, undertaken on August 12,1992 , in the area of the contaminant plume from the Otis Air Base sewage-disposal sand beds, support the recent hypothesis that the temporal variability can be attributed to the flux along the well screen reflecting the spatial heterogeneity in hydraulic conductivity and water chemistry of the aquifer near the well. The experiment consisted of withdrawing water from a well with a screened interval approximately $40 \mathrm{ft}$ long and sampling over time during a 5-hour period. Water samples also were collected from multilevel samplers surrounding the well before, during, and after the pumping of the well. Selected constituent concentrations and properties measured in samples collected from the discharging well showed different temporal trends during the 5-hour test. For example, the ferrous iron concentration decreased, the calcium concentration increased, and specific conductance remained relatively constant. The different trends are due to the different distributions of the constituents around the well as documented by analysis of water samples collected by the set of multilevel samplers. The observed trends are in agreement with the hypothesis and apparently are due not to the purging of the water standing in the well but to the flow and transport of the water and chemical species in the heterogenous aquifer in the immediate vicinity of the well.

1. U.S. Geological Survey, Reston, VA

2. U.S. Geological Survey, Marlborough, MA 


\author{
Brigid A. Rea ${ }^{1}$, Douglas B. Kent ${ }^{2}$, Linda C. D. Anderson ${ }^{2}$, \\ James A. Davis ${ }^{2}$, and Denis LeBlanc ${ }^{3}$
}

The active and abandoned sewage-disposal beds at the Massachusetts Military Reservation sewage treatment plant are a major source of inorganic contaminants, such as zinc, copper, and phosphate, in the Cape Cod aquifer, Massachusetts. The distribution and mobilities of these chemical constituents around the sewagetreatment plant are strongly affected by geochemical processes; extensive adsorption results in confinement of the most intensive concentrations to the near-source region including currently used and abandoned disposal facilities. Beyond the disposal facilities, zinc and copper movement continues to be controlled by sorption processes. Zinc and copper contamination was present at the same depths, although copper concentrations were much lower than those of zinc. Phosphate concentrations were high in the suboxic zone near the source and are controlled by adsorption to sediments. Phosphate concentrations in the anoxic zone were much lower and likely are controlled by ferrous phosphate solubility.

${ }^{1}$ U.S. Geological Survey, Boulder, Colorado

${ }^{2}$ U.S. Geological Survey, Menlo Park, California

${ }^{3}$ U.S. Geological Survey, Marlborough, Massachusetts 


\title{
EVALUATION OF GEOCHEMICAL INDICATORS OF METAL ADSORPTION IN A SAND AND GRAVEL AQUIFER, CAPE COD, MASSACHUSETTS
}

\author{
by C.C. Fuller ${ }^{1}$, J.A. Coston ${ }^{1}$, J.A. Davis ${ }^{1}$, and E. Dixon ${ }^{1}$
}

The geochemical properties of an aquifer sand that control metal-ion adsorption were investigated to determine their potential use as indicators of the spatial variability of metal adsorption in the aquifer. Over the length of a 4.5-meter long core, lead $(\mathrm{Pb})$ and zinc $(\mathrm{Zn})$ adsorption varied by a factor of two and four, respectively. $\mathrm{Pb}^{2+}$ and $\mathrm{Zn}^{2+}$ are adsorbed primarily by iron and aluminum oxide coatings on quartz-grain surfaces. Upon normalization to surface area, both $\mathrm{Pb}^{2+}$ and $\mathrm{Zn}^{2+}$ adsorption were significantly correlated with the amount of iron and aluminum dissolved from the aquifer material by partial chemical extraction. The use of partial chemical extraction combined with surface-area measurement as a potential indicator of metal adsorption in other aquifers needs to be tested.

${ }^{1}$ U.S. Geological Survey, Menlo Park, California 


\title{
SMALL-SCALE TRACER TESTS APPLIED TO THE MEASUREMENT OF IN STU DENTRIFCATION RATES IN A SEWAGE-CONTAMINATED AQUIFER, CAPE COD, MASSACHUSETTS
}

\author{
By Myron H. Brooks 1, Richard L. Smith1, and Stephen P. Garabedian 2
}

Small-scale naturalgradient tracer tests were used to measure in situ rates of denitrification in a nitrate-contaminated aquifer. Tracer solutions contained bromide. a conservative tracer, and acetylene, an inhibitor of nitrous oxide reductase.

Breakthrough of the tracer solution and production of nitrous oxide were monitored at multilevel samplers approximately 10 meters downgradient from the injection multilevel sampler for a period of up to 40 days. Calculated rates of denitrification from two tracer tests were 620 and 410 nanomoles $\mathrm{N}_{2} \mathrm{O}$ per liter of aquifer per day. These rates are on the low end of the range of reported rates in aquatic sediments, and are similar, but lower than, previous rate measurements made at the Cape Cod site by using flask and whole-core incubation techniques. Results of this study suggest that incubation techniques using aquifer sediments might slightly overestimate in situ denitrification rates in ground water. Peak concentrations of nitrous oxide lagged two days behind the peak concentrations of the conservative tracer in both tests. Work is currently underway to examine possible mechanisms for this result, and to model it by using a modified one dimensional advectiondispersion model containing a Michaelis-Menten term for nitrous oxide production.

1U.S. Geological Survey, Boulder, Colo.

2U.S. Geological Survey, Marlborough, Mass. 


\title{
Session 4--Poster Presentations
}

\author{
Galloway
}

\author{
Mirror Lake
}

Cape Cod 


\title{
USE OF COLUMN STUDIES AND A REACTIVE TRANSPORT MODEL TO MEASURE BIOLEGRADATION RATES OF HYDROCARBONS IN UNSATURATED POROUS MEDIA
}

\author{
by Ronald J. Baker ${ }^{1}$ and Arthur L. Baehr ${ }^{1}$
}

\begin{abstract}
A laboratory method for determining biodegradation rates of volatile hydrocarbons in unsaturated porous media (subsurface sedimentary material) was developed. Glass columns were filled with samples of porous media from the unsaturated zone at a gasolinecontaminated site in Galloway Township, N.J. Vapor-phase hydrocarbons (benzene, toluene, or p-xylene) were added to the porous media at the bottom of the column and were transported vertically along a concentration gradient. Aerobic biodegradation of hydrocarbons is indicated by the production of carbon dioxide $\left(\mathrm{CO}_{2}\right)$. The vapor-phase hydrocarbon and $\mathrm{CO}_{2}$ concentrations were monitored at several depths through sampling ports. Fluxes of hydrocarbons and $\mathrm{CO}_{2}$ leaving the column also were measured frequently. A mathematical model was used to calculate $\mathrm{CO}_{2}$ - production rates as a function of depth. These distributions and stoichiometric relations describing hydrocarbon biodegradation were used to calculate depth-specific hydrocarbon-degradation rates. Degradation rates generally increased with depth, and appeared to be coupled to soil-moisture content, which also increased with depth. Degradation rates also increased with the number of methyl groups on the aromatic ring, and rates were greater in unprocessed sediment than in sieved sand from which fine particles had been removed. This method could be used to determine optimum biodegradation conditions in the design of bioremediation strategies.
\end{abstract}

${ }^{1}$ U.S. Geological Survey, 810 Bear Tavern Rd., Trenton, N.J., 08628. 
HYDROGEOLOGY, CONTAMINANT DISTRIBUTION, AND BIODEGRADATION PROCESSES AT A GASOLINE-SPILL RESEARCH SITE IN GALLOWAY TOWNSHIP, NEW JERSEY

\author{
by Jeffrey M. Fischer, Nicholas P. Smith, and Arthur L. Baehr ${ }^{1}$
}

\title{
ABSTRACT
}

The hydrogeology of the Toxic Waste Program research site in Galloway Township, New Jersey, was characterized to determine factors controlling hydrocarbon-contaminant distribution and biodegradation. Sediments beneath the site are predominantly sand and clay. A localized zone of perched water forms above the regional water table. The direction of regional ground-water flow in the unconfined aquifer has varied from slightly north of east to eastsoutheast. Horizontal hydraulic gradients have been less than 0.005 since 1988 and estimates of average horizontal linear flow velocities range from 0.04 to 0.36 feet per day. A monitoring well provides a conduit for water to flow down from the perched-water zone to the unconfined part of the regional aquifer. The direction of ground-water flow near this well differs from regional flow directions.

Gasoline as a separate-phase liquid is floating on the regional water table in the leaky monitoring well and in the perched-water zone near the location from which the tank was exhumed. Dissolved hydrocarbons are present in the perched-water zone within a stable elliptical plume about 80 feet long and 40 feet wide in the 11 to 14 foot depth interval. Hydrocarbon contamination in the unconfined aquifer was detected downgradient from the leaky well, but contaminant location varied with changes in the direction of ground-water flow. The concentration of total aromatic hydrocarbons decreased downgradient as a result of dilution, dispersion, and biodegradation. Groundwater flow affects the types of hydrocarbon-degradation processes and the locations in which hydrocarbon contaminants are found. 


\title{
DETERMINATION OF VAPOR-PHASE DIFFUSION COEFFICIENTS FOR UNSATURATED-ZONE SEDIMENTS AT A GASOLINE-SPILL SITE IN GALLOWAY TOWNSHIP, NEW JERSEY
}

by Jeffrey M. Fischer, Ronald J. Baker, Matthew A. Lahvis, and Arthur L. Baehr ${ }^{1}$

\begin{abstract}
The rate of diffusion of gases through the unsaturated zone has been related to rates of microbial degradation of hydrocarbons at a gasoline-spill site in Galloway Township, New Jersey. The diffusion coefficient for the unsaturated porous medium is required to obtain rates of vapor movement from vapor-concentration measurements. Laboratory experiments were conducted on heterogeneous sediment cores to identify vapor-phase concentration profiles and vapor fluxes. A one-dimensional vapor-diffusion model based on the Stefan-Maxwell equations was used to calculate diffusion coefficients from these experiments. Diffusion coefficients obtained by using this method were lower than those predicted by using the Millington-Quirk equation, and were particularly significant for clayey sediments. Use of the theoretically calculated diffusion coefficients to calculate vapor flux and biodegradation rates at the study site would have led to overestimates of these rates when compared to those determined by using the experimental method.
\end{abstract}




\title{
A MULTISPECIES TRANSPORT MODEL TO SIMULATE \\ VAPOR EXTRACTION AND BIOVENTING REMEDIATION OF \\ UNSATURATED ZONES CONTAMINATED WITH GASOLINE
}

by

Craig J. Joss ${ }^{1)}$ and Arthur L. Baehr')

\begin{abstract}
Vapor extraction is an established method for removing spilled gasoline from the unsaturated zone. The technology involves the establishment of an unsaturated zone air-flow field by withdrawing and injecting air through dry wells and trenches. The success of a vapor-extraction installation depends fundamentally on the establishment of an air-flow field that intersects the contaminant and on the partitioning of the contaminant into the gaseous phase. Bioventing is a term applied to simultaneous venting and enhanced biodegradation of a contaminant. Aerobic biodegradation is stimulated by oxygen delivered to the unsaturated zone by air injection and withdrawal. A model to predict the transport and reaction of multiple chemical species in the gaseous phase under conditions of induced air flow has been developed to simulate the performance of vapor-extraction-based remediation. The model consists of a flow module and a reactive transport module. The flow module, named AIR3D, based on an adaptation of a ground-water flow simulator, defines the three-dimensional airvelocity field within which the chemicals are transported and react. The transport module solves a coupled system of conservation-of-mass equations, one for each chemical. Advectiondominated transport is assumed, which allows the conservation-of-mass equations to be defined along streamlines. In this paper, model applications and assumptions are summarized.
\end{abstract}

1) Dept. of Civil Engineering, Drexel University, Philadelphia, Pa.

2) U.S. Geological Survey, New Jersey District, West Trenton, N.J. 


\title{
METHOD FOR MONITORING BIODEGRADATION OF HYDROCARBONS IN UNSATURATED POROUS MEDIA
}

\author{
by John G. Nolan ${ }^{1}$, Ronald J. Baker ${ }^{2}$, and Arthur L. Baehr ${ }^{2}$
}

\begin{abstract}
A method for monitoring reaction rates of reactants and products during biodegradation of hydrocarbons in unsaturated porous media was developed. Stainless-steel bioreactors were filled with porous media that had been collected from a gasoline-spill site and used in biodegradation column studies. The purpose of the bioreactor study was to test the hypothesis that the microbial population in the porous media taken from the columns was at steady-state with respect to biomass production and endogenous respiration. This hypothesis allows hydrocarbon-biodegradation rates to be calculated from carbon dioxide production rates or oxygen consumption rates if mineralization stoichiometry is assumed. Toluene and p-xylene were the hydrocarbons used.
\end{abstract}

${ }^{1}$ Department of Civil Engineering, Drexel University, 32nd and Chestnut St., Philadelphia, Pa., 19104

${ }^{2}$ U.S. Geological Survey, 810 Bear Tavern Rd, Trenton, N.J., 08628. 
A COMPARISON OF TWO ANALYTICAL TECHNIQUES FOR IDENTIFYING AND MEASURING THE CONCENTRATIONS OF VOLATILE HYDROCARBONS IN GROUND WATER

by Curtis S. Phinney ${ }^{1}$ and Isabelle M. Cozzarelli ${ }^{1}$

Identification of monoaromatic hydrocarbons in ground water is commonly performed in circumstances where petrochemical contamination is suspected. Presence of certain of these species is considered indicative of petrochemical contamination. Most studies of ground-water contamination focus on the fate of benzene, ethylbenzene, toluene, and the xylenes (BTEX). However, a broad range of $\mathrm{C}_{6}-\mathrm{C}_{10}$ aromatic hydrocarbons can be present in ground water contaminated with petroleum products. In this study, results of a comparison of two analytical techniques for the identifying and measuring the concentrations of $\mathrm{C}_{6}-\mathrm{C}_{10}$ monoaromatic hydrocarbons are presented. The techniques investigated are pentane/water microextraction followed by gas chromatography/flame ionization detection (GC-FID), and purge and trap (open-loop) stripping of the sample followed by GC-Ion Trap detection (GC-ITD). Open-loop/GC-ITD allows the identification of $35 \mathrm{C}_{6}-\mathrm{C}_{10}$ aromatic hydrocarbons, compared to 21 identified by pentane/GC-FID. Compared to the pentane/GC method, higher sensitivity, higher selectivity, but lower precision were observed for samples analyzed by open-loop/GC-ITD. Hydrocarbon concentrations measured by the two techniques were generally in good agreement, within 88.6-99.7 percent for total monoaromatics. Concentrations of some trace constituents measured by pentane/GC-FID were higher under certain circumstances. For example, difficulty in resolving benzene from interferences by the pentane/GC-FID method sometimes resulted in considerably higher benzene and BTEX concentrations compared to open-loop/GC-ITD. At a sample site where hydrocarbon

concentrations were low, mean BTEX concentrations $(n=10)$ were 661 ug/L (micrograms per liter) by pentane/GC-FID compared to 490 ug/L by open-loop/GC-ITD. At the high concentration sample site, mean BTEX concentrations $(n=10)$ were $5,077 \mathrm{ug} / \mathrm{L}$ by pentane/GC-FID compared to $5,089 \mathrm{ug} / \mathrm{L}$ by open-loop/GC-ITD.

${ }^{1}$ U.S. Geological Survey, 431 National Center, Reston, VA 22092 


\title{
CHARACTERIZING BEDROCK FRACTURES IN OUTCROP FOR STUDIES OF GROUND-WATER HYDROLOGY: AN EXAMPLE FROM MIRROR LAKE, GRAFTON COUNTY, NEW HAMPSHIRE
}

\author{
by Christopher C. Barton ${ }^{1}$
}

The fractured-rock-hydrology study site at Mirror Lake, New Hampshire provides an opportunity to use the pavement method to characterize bedrock fractures at four highway roadcuts and one glacial pavement adjacent to the bedrock-hydrology test wells at Mirror Lake. The method entails the mapping of the fracture-trace network down to fracture-trace lengths of 1 meter on a detailed geologic base map. These maps, in turn form the basis for quantifying the scaling, interconnectedness, spatial distribution, and trace-length distribution for the fracture network. The characteristics of each mapped fracture measured include orientation, roughness, mineralization, aperture, and tectonic features, such as slickensides. The combined fracture data for the five pavement maps made to date indicate the following: Fracture orientation is highly variable with a preferred strike azimuth of approximately $30^{\circ} \mathrm{E}$., preferred fracture dips at $7^{\circ} \mathrm{NW}$., $50^{\circ} \mathrm{SE}$., and $82^{\circ} \mathrm{SE}$. Fracture roughness coefficients $(\mathrm{RC})$ range from 0 to $18(\mathrm{RC})$ values, with a mode at 5 to 6. Fracture aperture ranges from a lower cutoff of $0.005 \mathrm{~mm}$ to a maximum of $20.6 \mathrm{~mm}$, and the frequency distribution of fractures follows a power-law function with a scaling exponent of -1.5. Fracture-trace length ranges from a lower cutoff of $1 \mathrm{~m}$ to a maximum of $24.6 \mathrm{~m}$, and the frequency distribution follows a power-law function with a scaling exponent of -2.4. Fracture connectivity within the network is low compared to that of other sites around the country. Fracture mineralization includes iron-oxide coatings that appear have been biologically precipitated by ironfixing bacteria in the ground water and Liesegang bands that extend up to about 1 meter into the rock matrix. A paleohydrologic map of the iron-stained fracture traces reveals that ground water flowed in only part of the available network of the open and interconnected fractures.

1 U.S. Geological Survey, Denver, Colorado 


\title{
USE OF A BOREHOLE COLOR VIDEO CAMERA TO IDENTIFY LITHOLOGIES, FRACTURES, AND BOREHOLE CONDITIONS IN BEDROCK WELLS IN THE MIRROR LAKE AREA, GRAFTON COUNTY, NEW HAMPSHIRE
}

\author{
by Carole D. Johnson ${ }^{1}$
}

\begin{abstract}
A submersible color camera was used to describe bedrock lithologies and fractures in boreholes at the U.S. Geological Survey fractured-rock research site near Mirror Lake, Grafton County, N.H. From June through August 1992, video surveys were completed in 29 bedrock wells, which ranged in depth from 60 to 230 meters. Use of the submersible camera was prompted by a need to verify and provide additional descriptions of rock types identified in the wells. In two of the wells from which bedrock core was collected, video images together with drill cuttings were used to determine lithologies. These lithologies corresponded to lithologies determined directly from bedrock core samples collected from two wells. For wells from which core was not obtained, video images were used to improve the interpretations of the rock types that were based only on initial logs made at the time of drilling and later detailed examinations of drill cuttings. In addition, the images were used to inspect the conditions of the borehole walls for angularity, stability, or blockage.

${ }^{1}$ U.S. Geological Survey, Bow, NH
\end{abstract}


Velocity, Attenuation, and Dispersion Electromagnetic Tomography in Fractured Rock

\author{
David L. Wright ${ }^{1}$, Gary R. Olhoeft ${ }^{1}$, and Thomas P. Grover ${ }^{1}$
}

Hole-to-hole electromagnetic tomography data have been acquired from 15 pairs of wells at the Mirror Lake site, Grafton County, New Hampshire, using a high-speed borehole radar system designed and built by the U.S. Geological Survey. Although tomography has good theoretical and mathematical underpinnings, higher resolution, better dataacquisition methods, better tomographic processing and better visualization of the processed data than are currently available are needed if tomography is to achieve full potential as a geophysical tool for hydrologists. A 3-dimensional display of two velocity tomograms from data collected at the FSE well field at the Mirror Lake site illustrates the potential for mapping fracture zones in three dimensions. In addition, we show examples of velocity, attenuation, and dispersion tomograms made from a single data set in the well pair FSE4-FSE1. Comparisons between these three tomograms and with projected fractures from acoustic televiewer logs indicate that velocity, attenuation, and dispersion tomograms, though having some correlations with each other and with fractures, differ in shape. Because tomograms respond to lithology as well as to fractures, it might be necessary to use more than one type of tomogram to help discriminate between the response to fractures and the response to lithology in tomograms, unless the lithology is uniform.

${ }^{1}$ U.S. Geological Survey, Denver, Colo. 
USE OF WELL LOGS TO PREPARE THE WAY FOR PACKER STRINGS AND TRACER TESTS: LESSONS FROM THE MIRROR LAKE STUDY

by Frederick L. Paillet 1

\begin{abstract}
Although well logs can never replace conventional aquifer-testing techniques, a carefully designed suite of borehole measurements can identify the distribution of fractures along well bores. This information can be used to improve the effectiveness of hydraulic testing and water sampling. After nearly a decade of logging research at the Mirror Lake site, we have developed a combination of conventional and new techniques that have proven especially effective in preparing the way for subsequent installation of packer strings and tracer-test analysis. The approach consists of four steps: (1) characterizing the general structure and lithology of the rock mass by interpreting conventional well logs, (2) identifying and characterizing individual fractures by obtaining acoustic televiewer and other borehole image logs, (3) identifying the few fractures intersecting the well bore that produce water during pumping by running high-resolution flow logs in pumped and observation boreholes, and (4) inferring the pattern of fracture connectivity in the rock mass adjacent to boreholes by analyzing transient flow in boreholes at carefully selected locations between producing fractures. The application of this analysis allows geochemists and hydrologists to identify those locations where packers can be set to prevent communication between conductive fractures and to design efficient procedures for otherwise time-consuming aquifer and tracer tests.
\end{abstract}

${ }^{1}$ U.S. Geological Survey, Denver, Co 


\section{FIELD INSTRUMENTATION FOR MULTILEVEL MONITORING OF \\ HYDRAULIC HEAD IN FRACTURED BEDROCK AT THE MIRROR LAKE SITE, GRAFTON COUNTY, NEW HAMPSHIRE}

By Paul A. Hsieh ${ }^{1}$, Richard L. Perkins ${ }^{2}$, and Donald O. Rosenberry ${ }^{3}$

An adjustable and removable instrument, consisting of commercially available components, was developed for monitoring hydraulic heads at several depth intervals in bedrock wells. The intervals are isolated from each other by packers. Each interval is connected to an open pipe, so that the water level in the pipe equals the hydraulic head in the interval. The water levels are monitored by a potentiometer-float system and automatically recorded by a datalogger. The water levels are also measured manually by a water-level probe to check periodically the automatic measurements. The hydraulic-head monitoring instrument can be removed from the well to accommodate activities such as geophysical logging, water sample collection, or hydraulic testing. This instrumentation has been installed at 12 bedrock wells at the Mirror Lake site.

${ }^{1}$ U.S. Geological Survey, Menlo Park, CA

${ }^{2}$ U.S. Geological Survey, Bow, NH

${ }^{3}$ U.S. Geological Survey, Lakewood, CO 


\title{
A NEW METHOD OF PERFORMING CONTROLLED INJECTION OF TRACED FLUID IN FRACTURED CRYSTALLINE ROCK
}

\author{
Allen M. Shapiro1 and Paul A. Hsieh²
}

\begin{abstract}
A new method is presented for the controlled injection of traced fluids into permeable intervals in bedrock wells. Prior to the tracer injection, an inflatable packer is used to seal fractures in the injection interval, allowing downhole mixing of the tracer with borehole water. After a uniform mixture is achieved, the packer is deflated to inject the traced fluid into the fractures. The injection apparatus requires smooth borehole walls and no more than a few closely spaced permeable fractures in the injection interval. In this paper, operation of the equipment is presented for the instantaneous injection of a known volume of traced fluid into the formation. The equipment can also accommodate other injection procedures, such as the continuous injection of traced fluids into the formation.

1U.S. Geological Survey, Reston, VA

2U.S. Geological Survey, Menlo Park, CA
\end{abstract}




\section{A CONCEPTUAL MODEL FOR ESTIMATING REGIONAL GROUND-WATER \\ VELOCITY IN BEDROCK OF THE MIRROR LAKE AREA, GRAFTON COUNTY, NEW HAMPSHIRE}

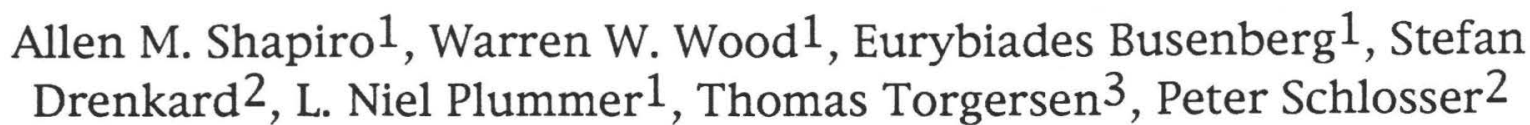

\section{ABSTRACT}

Estimation of regional ground-water velocities requires a knowledge of the residence time of the ground water and the distance it has traveled. Ground-water residence times are estimated in the Mirror Lake area on the basis of concentrations of chlorofluorocarbons and the parent-daughter isotopes tritium and helium. The distance the ground water has traveled, however, cannot be identified in the Mirror Lake area because there is no single area of recharge to the bedrock and the heterogeneity of hydraulic properties of the bedrock indicate that a regional flow line cannot be conceptualized from successive down-gradient sampling locations. Measurements of alkalinity in water samples collected from fractures in the bedrock are positively correlated with ground-water age. The alkalinity is controlled by the concentration of bicarbonate ions, and carbon isotopes indicate that the bicarbonate concentration is the result of dissolution of calcite in the rock matrix. The diffusion of bicarbonate ions from the rock matrix to fractures is hypothesized as a second indicator of the residence time of ground water in the bedrock. A simple model of ground-water flow and the transport of bicarbonate ions in the bedrock is proposed to investigate the relations among ground-water velocity, residence time and alkalinity. The model consists of a single fracture in contact with a rock matrix from which the average ground-water velocity in the bedrock can be estimated. From this simple conceptual model, the length of paths of fluid movement in the bedrock and the average bedrock velocity can be estimated. This conceptual model, however, must be reconciled with other geochemical data that indicates that ground waters of various ages are mixing either naturally or as a result of ground-water sampling.

1U.S. Geological Survey, Reston, VA

${ }^{2}$ Lamont-Doherty Earth Observatory, Department of Geochemistry, Palisades, NY 3University of Connecticut, Department of Marine Sciences, Groton, CT 


\section{HELIUM ISOTOPE ANALYSIS AND TRITIUM-HELIUM}

\section{AGE DATING IN THE MIRROR LAKE BASIN, GRAFTON COUNTY, NEW HAMPSHIRE}

Stefan Drenkard1, Thomas Torgersen ${ }^{2}$, Ralf Weppernig 1 , Kenneth Farley ${ }^{1}$, Peter Schlosser 1 , Robert L. Michel ${ }^{3}$, Allen M. Shapiro ${ }^{3}$ and Warren W. Wood 3

Ground-water samples from the Mirror Lake fractured bedrock site in New Hampshire were analyzed for tritium $(3 \mathrm{H})$ and its decay product helium-3 $\left({ }^{3} \mathrm{He}\right)$, as well as for helium-4 $\left({ }^{4} \mathrm{He}\right)$ and neon $(\mathrm{Ne})$. Paired measurements of the radioactive mother/daughter pair ${ }^{3} \mathrm{H}-3 \mathrm{He}$ can be used to determine ground-water age--that is, the time elapsed since the water last equilibrated with the atmosphere. Preconditions for precise calculations by this method are separation of the tritiogenic 3 He signal from other He components dissolved in water (atmospheric, nucleogenic and mantle ${ }^{3} \mathrm{He}$ ) by use of ${ }^{4} \mathrm{He}$ and $\mathrm{Ne}$ data. This separation technique is complicated for samples analyzed from the Mirror Lake site because of a large helium excess with an estimated ${ }^{3} \mathrm{He} /{ }^{4} \mathrm{He}$ ratio of about $1.65 \times 10^{-6}$. Data from shallow wells yield reliable ${ }^{3} \mathrm{H}-3 \mathrm{He}$-based ages, but the error in the age calculation increases with depth because of an increase in excess He and the related corrections. Possible origins of the excess helium are discussed, and mixing as an apparent source is ruled out. Helium isotope measurements of crushed rock samples indicate that the excess helium does not have its source in the local rock. On the basis of the observed increase in ${ }^{3} \mathrm{H}-3 \mathrm{He}$ age and presence of excess helium with depth, the potential of the ${ }^{4} \mathrm{He}$ concentration as an additional proxy age-dating tool is explored.

1Lamont Doherty Earth Observatory, Palisades, NY

2University of Connecticut, Groton, CT

3U.S. Geological Survey, Reston, VA 


\title{
CONCENTRATIONS OF CHLOROFLUOROCARBONS AND OTHER GASES IN GROUND WATER AT MIRROR LAKE, NEW HAMPSHIRE
}

\author{
By Eurybiades Busenberg1 and L. Niel Plummer ${ }^{1}$
}

The concentrations of chlorofluorocarbons (CFCs) were measured in samples of ground water from 51 different depth intervals in wells completed in the lowpermeability glacial till and fractured crystalline rocks at Mirror Lake. The CFC concentrations were used to model water-recharge ages. The ground-water ages generally increased with depth from land surface and were consistent with the reconstructed tritium $\left({ }^{3} \mathrm{H}\right)$ concentrations. $\mathrm{A} 6^{\circ} \mathrm{C}$ water-recharge temperature was obtained from the nitrogen $\left(\mathrm{N}_{2}\right)$ to argon $(\mathrm{Ar})$ ratios from the wells completed in the glacial till. The dissolved $\mathrm{N}_{2}$, Ar, and helium concentrations generally increased with depth from land surface. Excess air in ground waters ranges from about 0 to 19 cubic centimeters per liter in some deep wells. In addition to the excess air, some wells contain significant amounts of excess $\mathrm{N}_{2}$. Enrichment in the concentrations of sulfate, calcium, and magnesium were present in some ground waters with CFC-recharge ages of 1963 to 1973.

1U.S. Geological Survey, Reston, VA 


\title{
FACTORS AFFECTING RECHARGE TO CRYSTALLINE ROCK IN THE MIRROR LAKE AREA, GRAFTON COUNTY, NEW HAMPSHIRE
}

\author{
by Philip T. Harte ${ }^{1}$ and Thomas C. Winter ${ }^{2}$
}

The effects of local and regional-flow processes on recharge to crystalline rock are investigated by use of numerical, cross-sectional models of ground-water flow, comparison of vertical-head gradients between lower piezometers in drift and upper bedrock wells, and chemical mass-balance models of net differences in water chemistry. This paper describes factors that control recharge to crystalline rock in the Mirror Lake area. Four principal factors that affect bedrock-

recharge patterns are (1) relief of land and bedrock surface above ground-water discharge areas, (2) lateral trends in bulk-rock horizontal hydraulic conductivity, (3) local topographic features, and (4) drift stratigraphy. Factors 1 and 2 control the regional distribution of bedrock recharge, whereas the local distribution of bedrock recharge is controlled by factors 3 and 4 .

${ }^{1}$ U.S. Geological Survey, Bow, NH

${ }^{2}$ U.S. Geological Survey, Lakewood, CO 


\title{
NUMERICAL SIMULATION OF DOWNWARD MOVEMENT OF SOLUTES DURING A NATURAL-GRADIENT TRACER TEST IN SAND AND GRAVEL, CAPE COD, MASSACHUSETTS
}

\author{
by Denis R. LeBlanc ${ }^{1}$ and Michael A. Celia ${ }^{2}$
}

\begin{abstract}
A numerical, finite-element, solute-transport model was used to test the hypothesis that the downward movement of a tracer cloud observed during a naturalgradient tracer test in sand and gravel on Cape Cod, Massachusetts, was caused by density-induced sinking and recharge from precipitation. The tracer solution, which included the nonreactive tracer, bromide, was 0.1 percent denser than the ambient ground water. The center of mass of the bromide cloud moved vertically downward about 3.2 meters during 237 days of transport. The model simulated density-dependent flow and solute transport along a two-dimensional vertical section 25 meters high and 136 meters long aligned with the direction of ground-water flow. Transport of the bromide cloud was simulated for a period of 237 days divided into 191 time steps. The temporal pattern of recharge applied to the top boundary of the model was determined from daily precipitation and estimates of evapotranspiration. On the basis of an analysis of spreading of the bromide cloud during the tracer test, dispersivity increased with time in the simulation asymptotically from 0.05 to 0.96 meters. The simulated downward movement after 237 days was 2.1 meters (about two thirds of the observed movement). The simulation showed that density-induced downward movement was most important during the first 50 days of transport when the density contrast between the ambient ground water and the tracer cloud was greatest. Earlier work indicated that the difference between the observed and simulated downward movement may be due, in part, to twodimensional simulation of the three-dimensional flow that occurred around the tracer cloud as it moved downward through the ambient ground water. Additional simulations showed how the amount of downward movement is affected by the shape and size of the initial bromide cloud; aquifer properties, such as dispersivity and anisotropy of hydraulic conductivity; and the type of boundary used to represent the water table in the model.
\end{abstract}

${ }^{1}$ U.S. Geological Survey, Marlborough, MA

${ }^{2}$ Dept. of Civil Engineering and Operations Research, Princeton Univ., Princeton, NJ 


\title{
HEAVY-METAL TRANSPORT IN A SAND AND GRAVEL AQUIFER WITH VARIABLE CHEMICAL CONDITIONS, CAPE COD, MASSACHUSETTS
}

\author{
by James A. Davis ${ }^{1}$, Douglas B. Kent ${ }^{1}$, Jennifer A. Coston ${ }^{1}$, \\ and Kathryn M. Hess ${ }^{2}$
}

\begin{abstract}
An overview is presented of a field-based research program that is examining the significance of chemical speciation and variable aquifer chemistry on the transport of toxic metals in ground water. Natural-gradient tracer tests and laboratory experiments with subsurface materials have been used to identify the most important chemical reactions that influence the transport of chromium(VI) and metal-ethylenediaminetetraacetic acid (EDTA) complexes in the aquifer at the Cape Cod Toxic-Substances Hydrology Research site. The field experiments are being conducted in an uncontaminated, recharge zone and a mildly reducing, sewage-contaminated zone of the shallow, sand and gravel aquifer. The results of several years of research at the site have been used to design a large-scale tracer test at the site (begun in April 1993) involving eight tracers (bromide, chromium, zinc, copper, lead, nickel, EDTA, and potassium). The new experiment will be the most complex and detailed investigation of multispecies, multireaction transport ever conducted in the field. The pertinent results of previous small-scale tracer tests are reviewed, and the objectives and expected results of the new tracer test are discussed.
\end{abstract}

${ }^{1}$ U.S. Geological Survey, Menlo Park, California

2 U.S. Geological Survey, Marlborough, Massachusetts 


\section{SPATIAL VARIABILITY OF METAL-ION ADSORPTION AND HYDRAULIC CONDUCTIVITY IN A SAND AND GRAVEL AQUIFER, CAPE COD, MASSACHUSETTS}

by Kathryn M. Hess ${ }^{1}$, James A. Davis ${ }^{2}$, Christopher C. Fuller ${ }^{2}$, and Jennifer A. Coston ${ }^{2}$

The spatial variability of metal-ion adsorption and hydraulic conductivity was assessed from the results of laboratory experiments on 375 sediment samples collected from 14 boreholes in a glacial outwash, sand and gravel aquifer on Cape Cod, Massachusetts. Zinc and lead adsorption were measured in batch experiments. Hydraulic conductivity was estimated on the basis of grain-size distributions. Mean lead adsorption is greater than mean zinc adsorption; mean hydraulic conductivity is similar to that measured previously in this aquifer. All three properties vary significantly within the aquifer; variability in zinc adsorption is greater than variability in lead adsorption. A strong positive correlation is observed between the two metal-ion adsorptions. There is a statistically significant, but small, negative correlation between lead adsorption and hydraulic conductivity and a statistically insignificant negative correlation between zinc adsorption and hydraulic conductivity. Vertical correlation scales obtained by fitting an exponential model to experimental semivariograms equaled $0.10-0.26$ meters for the hydraulic-conductivity and adsorption data sets. Similar vertical correlation scales were determined in an earlier study of the variability of hydraulic conductivity measured by use of permeameter and flowmeter tests. A horizontal correlation structure could not be identified in this study, possibly because the horizontal spacing between boreholes was large relative to the correlation scales and the number of samples was small.

${ }^{1}$ U.S. Geological Survey, Marlborough, Mass.

${ }^{2}$ U.S. Geological Survey, Menlo Park, Calif. 
PRELIMINARY TYPE-CURVE ANALYSIS OF AN AQUIFER TEST IN AN UNCONFINED SAND AND GRAVEL AQUIFER, CAPE COD, MASSACHUSETTS

\author{
By Allen F. Moench ${ }^{1}$, Denis R. LeBlanc ${ }^{2}$, \\ and Steven P. Garabedian ${ }^{2}$
}

\title{
ABSTRACT
}

An aquifer test was conducted in a sand and gravel, glacialoutwash deposit on Cape Cod, Massachusetts. A partially penetrating well was pumped at a constant rate of 320 gallons per minute for 72 hours. Changes in hydraulic head were observed at 20 locations through observation wells and piezometers distributed both radially and vertically within the saturated zone of the aquifer. The test was analyzed using Neuman's analytical model for flow to a partially penetrating well in a water-table aquifer. On the basis of geophysical well logs, cores, and other investigations conducted in the local area, the aquifer was initially assumed to have a saturated thickness of 80 feet for the purpose of analysis. However, drawdown observed in a piezometer located 106 feet below the water table, and an initial analysis revealed a complete lack of conformity between theoretical and observed drawdown in piezometers located near the pumped well. Also, the computed horizontal hydraulic conductivity was twice that obtained by independent studies. ongoing studies of the regional stratigraphy indicate that the saturated thickness of the aquifer is actually closer to 160 feet than to 80 feet. By increasing the assumed saturated thickness to 160 feet, the theoretical drawdown was found to match observed drawdown for most of the test period at nearly all points of observation. Results indicate that there is a remarkable degree of aquifer homogeneity with respect to flow at the scale of the test. The aquifer transmissivity and specific yield were determined to be 38 feet squared per minute and 0.23 , respectively, and the ratio of vertical to horizontal hydraulic conductivity was estimated to be about 1:2.

1 U.S. Geological Survey, Menlo Park, Calif.

2 U.S. Geological Survey, Marlborough, Mass. 


\title{
EFFECTS OF CHANGES IN AQUIFER PROPERTIES ON SIMULATED
}

FLUID-PARTICLE PATHLiNES, CAPE COD, MASSACHUSETTS

\author{
by John P. Masterson 1 and Donald A. Walter ${ }^{1}$
}

\begin{abstract}
A ground-water-flow model is being developed by the U.S. Geological Survey (USGS) to estimate the paths of contaminants from the Massachusetts Military Reservation and, in particular, to determine whether these contaminants will effect public supply wells, ponds, streams, and coastal embayments. Preliminary model results determined by use of the regional-scale flow model of western Cape Cod developed by the USGS indicate that the pathlines of contaminants emanating from the infiltration beds of the Massachusetts Military Reservation sewage- treatment plant do not coincide with the known extent of the contaminant plume. Modifications to aquifer properties simulated by the model result in a similar head distribution and stream-discharge rates for the aquifer, yet markedly different contaminant pathlines. Therefore, calibration simply based on head and stream discharge matching is insufficient for transport analysis. Accurate calibration might require the incorporation of contaminant information to use ground-water-flow models as tools for predicting plume migration.
\end{abstract}

${ }^{1}$ U.S Geological Survey, Marlborough, MA 


\title{
POTENTIAL LONG-TERM EFFECTS OF PHOSPHATE CONTAMINATION IN AN ALLUVIAL AQUIFER, CAPE COD, MASSACHUSETTS
}

\author{
by Kenneth G. Stollenwerk ${ }^{1}$
}

Phosphate in the Ashumet Valley sewage plume, located near Falmouth, Massachusetts, could increase the rate of eutrophication in Ashumet Pond. A series of column experiments have been initiated to identify the geochemical processes affecting transport of phosphate in this aquifer. The principal focus of these experiments is to determine the amount and rate of phosphate desorption from aquifer sediment after sewage disposal is stopped. The first set of column experiments simulated the oxic zone that surrounds the core of the plume. Results indicate that the sediment has a relatively high capacity to adsorb phosphate and that adsorption is kinetically controlled. The rate of desorption is slow. Approximately 160 pore volumes were eluted before the phosphate concentration decreased to levels considered not to cause eutrophication; half the phosphate was still adsorbed on the sediment. A one-dimensional solute-transport code simulated the column data reasonably well; however, a kinetic term needs to be included in the model to improve accuracy.

${ }^{1}$ U.S. Geological Survey, Denver, co 


\title{
BACKGROUND AQUEOUS CHEMISTRY AND EFFECTS OF CARBON DIOXIDE VARIATIONS IN RECHARGE IN SHALLOW GROUND WATER IN A GLACIAL OUTWASH AQUIFER
}

\author{
by Roger W. Lee ${ }^{1}$
}

\begin{abstract}
Previous geochemical research at the Otis Air Base Site, Cape Cod, Massachusetts, determined that the principal geochemical process developing background water chemistry of shallow ground water is $\mathrm{CO}_{2}$-controlled hydrolysis of sodium feldspars. Preliminary geochemical modeling however, demonstrated that $\mathrm{CO}_{2}$ sources should vary laterally over the project area. Field analyses of unsaturated zone gases showed variations in available $\mathrm{CO}_{2}$ for recharge waters. These variations depend on land use and vegetative cover in the area of ground-water recharge. On the basis of measurements of $\mathrm{CO}_{2}$ concentrations in unsaturated-zone gases from 20 sites, $\mathrm{CO}_{2}$ dissolved in recharge water should vary from about 0.035 to 1.000 millimoles per liter in the project area. The various land-use practices and local surface features in and around Otis Air Base (residential subdivisions, golf courses, large cultivated grass fields, kettle ponds, and woodlands) are associated with variations in the amount of $\mathrm{CO}_{2}$ in the unsaturated zone.
\end{abstract}

1U.S. Geological Survey,Water Resources Division, Austin, Texas 


\title{
OVERVIEW OF RESEARCH ON THE DISTRIBUTION AND ROLE OF PROTOZOA IN AN ORGANICALLY CONTAMINATED AQUIFER AT CAPE COD, MASSACHUSETTS
}

\author{
N.E. Kinner ${ }^{1}$ and R.W. Harvey ${ }^{2}$
}

\begin{abstract}
The distribution, nature, and role of protozoa that inhabit contaminated and uncontaminated ground water were investigated at the U.S. Geological Survey (USGS) Cape Cod Toxic-Substances Hydrology Research Site. New information has included identification of large protozoan populations (up to $10^{5} / \mathrm{gram}$ dry weight) in anoxic zones of the aquifer; a lack of correlation between dissolved oxygen concentrations and protozoan abundance or degree of encystment; a strong relation among concentrations of dissolved organic carbon, phosphate, sulfate, nitrate, numbers of free-living bacteria (FLB) and protozoa; and a ratio of FLB to protozoa that is 10-100 times lower than that typically found in other aqueous environments. An improved direct-counting procedure has allowed more accurate enumeration of protozoa in sandy, aquifer sediments than was previously possible.
\end{abstract}

${ }_{1}^{1}$ Dept. Civil Engineering, University of New Hampshire, Durham, NH

${ }^{2}$ U.S. Geological Survey, WRD, Boulder, CO 


\title{
TRANSPORT OF INDIGENOUS PROTOZOA IN A SANDY AQUIFER, CAPE COD, MASSACHUSETTS
}

\author{
R.W. Harvey ${ }^{1}$, N.E. Kinner ${ }^{2}$, D. MacDonald ${ }^{2}$, A.L. Bunn ${ }^{2}$, and D.W. Metge ${ }^{1}$
}

Transport of flagellates in sandy, organically contaminated aquifer sediments was investigated in a small-scale ( $2 \mathrm{~m}$ travel distance) natural-gradient tracer test in Cape Cod. The flagellates (average cell size, 2-3 $\mu \mathrm{m}$ ), which appear to be common in the Cape Cod aquifer, were grown in Cerophyl, labeled with hydroethidine (a vital eukaryotic stain), and coinjected into aquifer sediments along with a conservative tracer (bromide). Rates of immobilization in undisturbed aquifer sediments were more than two orders of magnitude greater than those observed earlier for indigenous ground-water bacteria.. The high rate of immobilization appeared to be related to the surface chemistries of the flagellates and not their size. Retardation for the flagellates was two- to three-fold greater than that generally observed for indigenous groundwater bacteria. Apparent dispersion was also significantly greater for the flagellates than for the bacteria and was much closer to that observed earlier for highly surface-active, microbial-sized, carboxylated-latex microspheres. The data suggest that flagellates are probably transported slowly through the aquifer.

1U.S. Geological Survey, WRD, Boulder, CO

2Dept. Civil Engineering, University of New Hampshire, Durham, NH 


\title{
USE OF STATIC COLUMN EXPERIMENTS TO IDENTIFY FACTORS AFFECTING BACTERIAL ATTACHMENT IN CONTAMINATED AQUIFER SEDIMENTS FROM CAPE COD, MASSACHUSETTS
}

\author{
By David W. Metge 1 , Ronald W. Harvey ${ }^{1}$, \\ George R. Aiken 1 , and Larry B. Barber, II ${ }^{1}$
}

The mineralogy of, sediment in, and the geochemistry of ground water from the Cape Cod contaminated aquifer have been found to affect bacterial attachment and transport through aquifer sediments. Static column experiments, under simulated aquifer conditions, were used to identify chemical factors (for example, $\mathrm{pH}$, the concentration of dissolved organic carbon [DOC], the presence and concentration of divalent ions and other competing ligands, and ionic strength) which can affect bacterial transport in the subsurface. $\mathrm{pH}$ strongly influenced bacterial attachment in uncontaminated sediments; an increase in $\mathrm{pH}$ from 5.8 to 7.9 resulted in a 70 percent drop in fractional bacterial attachment. Also, attachment of bacteria to aquifer sediments was substantially affected by changes in the amount and type of DOC from both contaminated and uncontaminated ground water. Finally, ionic strength and divalent ions, such as sulfate, were found to affect bacterial attachment. The experiments indicate that competitive and (or) synergistic interactions can operate under different $\mathrm{pH}$ conditions. Thus, different geochemical conditions can affect cell-grain surface interactions by competing with bacteria for binding sites and (or) modifying grain or cell-surface characteristics.

1 U.S. Geological Survey, Boulder, CO 


\section{Session 5--Picatinny}




\title{
OVERVIEW OF RESEARCH ACTIVITIES ON THE TRANSPORT AND FATE OF CHLORINATED SOLVENTS IN GROUND WATER AT PICATINNY ARSENAL, NEW JERSEY, 1991-93
}

\author{
by Thomas E. Imbrigiotta ${ }^{1}$ and Mary Martin ${ }^{1}$
}

The U.S. Geological Survey is conducting an interdisciplinary research study of ground-water contamination by chlorinated solvents, particularly trichloroethylene (TCE), at Picatinny Arsenal, New Jersey. This paper summarizes the results of seven ongoing research studies investigating the processes of desorption, volatilization, and biotransformation and their effects on the fate and transport of TCE in the ground-water system.

Results of flow-through column experiments showed that contaminated aquifer sediments can act as a continuing source of TCE to the ground water. A one-dimensional model was developed to simulate the column desorption data. The model simulates an initial rapid-stage desorption by an equilibrium process, and a second slower-stage desorption by a kinetic mechanism. Concentrations of TCE sorbed to soil did not differ significantly whether the samples were air-dried overnight prior to methanol extraction or whether the extraction was conducted on wet samples and the results were corrected for the TCE content of the soil moisture.

Results of a field experiment to study the dynamics of TCE volatilization in the unsaturated zone during infiltration indicated that an equilbrium distribution of TCE between soil gas and soil water was not achieved. A two-phase transport model of gas and aqueous phases was capable of simulating the field soil-gas and soil-water TCE data after modification to include a constant-flux term for desorption of TCE from soil to water.

Anaerobic biotransformation rates calculated on the basis of measured field TCE concentrations and estimated ground-water travel time between sites generally were greater than those previously measured in laboratory soil microcosm experiments.

A reactive two-dimensional multispecies transport model is being used to simulate desorption, volatilization, and microbial degradation of TCE along the central axis of the plume by using rates estimated from results of other studies at the site. The formation and transport of TCE degradation products cis-1-2-dichloroethylene and vinyl chloride also are simulated.

Aerobic cometabolic biotransformation of TCE and cis-1,2dichloroethylene can be stimulated in soil microcosms constructed with soils from the unsaturated zone near Building 24 at the arsenal if the indigenous methanotrophic bacteria are supplied with appropriate amounts of oxygen, methane, and nutrients.

Preliminary results of a study to determine whether surfactants can enhance the removal of TCE from aquifer sediments during pump-and-treat remediation indicate that addition of the nonionic surfactant Triton-X 100 is effective in artificially increasing the rate of mass transfer of TCE from soil to the aqueous phase.

\footnotetext{
${ }^{1}$ U.S. Geological Survey, 810 Bear Tavern Rd., Suite 206, West Trenton, NJ 08628
} 
SIMULATION OF TRANSPORT, DESORPTION, VOLATILIZATION, AND MICROBIAL DEGRADATION OF TRICHLOROETHYLENE IN GROUND WATER AT PICATINNY ARSENAL, NEW JERSEY

\section{By Mary Martin ${ }^{1}$}

\section{ABSTRACT}

The fate of dissolved trichloroethylene in ground water at Picatinny Arsenal, New Jersey, is being analyzed with a reactive multispecies transport model of a two-dimensional vertical section along the central axis of the plume. The model simulates the desorption, volatilization at the water table, and microbial degradation of trichloroethylene. The formation and transport of the degradation products cis-1-2-dichloroethylene and vinyl chloride also are simulated. Results of this modeling analysis demonstrate the applicability and usefulness of the multispecies two-dimensional transport code to contaminant fate and transport studies.

${ }^{1}$ U.S. Geological Survey, West Trenton, NJ 


\title{
Simulation of Trichloroethylene Volatilization in the Unsaturated Zone during a Field Infiltration Experiment at Picatinny Arsenal, New Jersey
}

\author{
by H. Jean Cho' ${ }^{1}$, James A. Smith ${ }^{2}$, and Peter R. Jaffé ${ }^{3}$
}

\begin{abstract}
A field experiment was conducted at Picatinny Arsenal, New Jersey, to study the dynamics of trichloroethylene as it volatilizes from contaminated ground water to land surface during infiltration. It was found that the gas- and water-phase concentrations of TCE were not in equilibrium in the unsaturated zone during infiltration. A mathematical model was developed to simulate the volatilization of TCE in the unsaturated zone. Gas-water mass-transfer-rate constants were calibrated to the data. The mass-transfer limitations of a volatile organic compound between the gas and liquid phases were described explicitly in the model. The water-infiltration rate was 0.34 centimeters per hour, and TCE desorption from the soil matrix was significant. Slow desorption of TCE from the soil matrix was incorporated in the mathematical model.
\end{abstract}

\footnotetext{
${ }^{1}$ Department of Civil and Environmental Engineering, Vanderbilt University, Box 1658-B, Nashville, TN 37235

${ }^{2}$ Department of Civil Engineering, University of Virginia, Thornton Hall, Charlottesville, VA 229032442

${ }^{3}$ Department of Civil Engineering and Operations Research, Princeton University, Princeton, NJ 08544
} 
By Theodore A. Ehlke ${ }^{1}$ and Thomas E. Imbrigiotta ${ }^{1}$

This study determined the feasibility of in situ cometabolic remediation of gas-phase chlorinated ethenes at Picatinny Arsenal, New Jersey.

Cometabolic biotransformation of trichloroethylene (TCE) and cis-1,2dichloroethylene (cis-DCE) was studied in a laboratory experiment with unsaturated-zone soil cores collected within a contaminant plume near the source. Concentrations of TCE and cis-DCE in soil, soil gas, and ground water within the plume also were quantified. At the highest concentrations studied, TCE $(3.2 \mu \mathrm{M})$ mixed with cis-DCE $(4.3 \mu \mathrm{M})$ was degraded most rapidly $(0.05 \mu \mathrm{mol}$ $\mathrm{TCE} / \mathrm{L} / \mathrm{d}, 0.09 \mu \mathrm{mol} \mathrm{cis}-\mathrm{DCE} / \mathrm{L} / \mathrm{d}$ ) in acclimated soils with a 3 -percent methane headspace. Degradation of TCE at lesser concentrations $(1.3 \mu \mathrm{M})$ as the only chloroethene present in fertilized, acclimated soil was much faster $(0.12 \mu$ mol $\mathrm{TCE} / \mathrm{L} / \mathrm{d}$ ) in the presence of 1.2 percent methane. Most of the unsaturated-zone TCE ( $>99.9$ percent) near the contaminant source was sorbed to soil. Results of soil-gas analyses indicate that the concentration of unsaturated-zone TCE near the contaminant source was highest $(0.32 \mu \mathrm{M})$ in a shallow clay layer, and decreased with depth to the water table. This indicates that the original contamination was mostly from condensed TCE which drained from a degreasing tank to a nearby dry well. The concentration of TCE in unsaturated-zone soil elsewhere throughout the plume increased with depth, indicating that most unsaturated-zone TCE contamination resulted from volatilization losses of TCE from contaminated shallow ground water.

$\overline{1_{U} . S . ~ G e o l o g i c a l}$ Survey, 810 Bear Tavern Road, Suite 206, West Trenton, New Jersey 08628 


\section{Session 6--Methods, Techniques, and Research on Agricultural Chemicals in the Midwest I}




\title{
Sampling Borehole Flow to Quantify Aquifer Cross- Contamination by Volatile Organic Compounds
}

\author{
By Ronald A. Sloto ${ }^{1}$
}

A combination of borehole geophysical methods, measurements of vertical borehole flow, and analyses of borehole-fluid samples were used to assess the extent of aquifer cross-contamination in the Stockton Formation in Hatboro, Pennsylvania. The Stockton consists of interbedded nonmarine sandstone and siltstone-mudstone. Most industrial, public-supply, and monitoring wells drilled into the Stockton Formation are constructed as open holes with short casings and are open to multiple water-bearing zones. Caliper, fluid-resistivity, fluid-temperature, natural-gamma, and single-pointresistance logs were run in 19 boreholes 149 to 656 feet deep to locate water-bearing fractures and determine zones of vertical borehole-fluid movement. The direction and rate of vertical borehole-fluid movement was measured by injecting a slug of high-conductance fluid at a specific depth in the borehole and monitoring the movement of the slug with the fluid-resistivity tool. After intervals of borehole flow were determined, samples of moving fluid were extracted from nine boreholes at a rate less than that of the measured borehole flow and analyzed for volatile organic compounds. An estimated 80.9 kilograms per year of volatile organic compounds were estimated to be moving downward through the sampled boreholes from the contaminated, upper part of the aquifer to the lower part, which is tapped by public-supply wells. Trichloroethylene accounts for 94 percent and 1,1,1-trichloroethane accounts for 3 percent of the compounds.

${ }^{1}$ U.S. Geological Survey, Malvern, Pa. 


\section{ISOLATION OF LIPOPHILIC ORGANIC CONTAMINANTS \\ ALONG THE UPPER MISSISSIPPI RIVER USING A SEMIPERMEABLE MEMBRANE DEVICE}

by Geoffrey S. Ellis and Colleen E. Rostad U.S. Geological Survey, Arvada, Co

The detection of many environmental contaminants in water is often hindered by their transient nature and low concentration. However, these compounds can represent a significant environ-mental hazard to biota and humans through bioconcentration. Traditional methods of analyzing aquatic biota are complicated by variations in species, sex, age, reproductive stage, location, behavioral patterns, metabolism, and water conditions. A new sampling device consisting of a tubular semipermeable membrane of lowdensity polyethylene filled with synthetic fish fat, triolien, which mimics the mechanism of bioconcentration, may resolve some of these problems. To evaluate the effectiveness of these sampling devices, they were deployed at nine sites along the upper Mississippi River; caged fish at three of these sites were used for comparison purposes. The devices and caged fish were collected over an eight-week period, and indigenous fish were collected at the end of the study. Compounds were extracted from the triolien by back dialysis into an appropriate solvent. Fish tissues were ground and extracted wet into a solvent and the lipid removed. All samples were analyzed by gas chromatography/ mass spectrometry (GC/MS). Target compounds were pesticides, herbicides, and polychlorinated biphenyls (PCBs). Comparisons of compound concentrations in the fish. samples and sampling devices will be used to determine the effectiveness of this technique as a monitoring tool for bioconcentration. 


\section{A SAMPLE-FREEZING DRIVE SHOE FOR A WIRELINE-PISTON CORE SAMPLER}

\section{by Fred Murphy ${ }^{1}$ and W.N.Herkelrath ${ }^{1}$}

Loss of fluids and sample during retrieval of cores of noncohesive sediments results in incorrect measures of fluid distributions and a less-than-ideal measure of the stratigraphic position of the sample. In order to reduce these errors, we developed a hollow drive shoe that allows freezing in place the lowest 75 millimeters of a 48-millimeter-diameter, 1.5meter-long sediment sample taken using a commercial wireline-piston-core sampler. The end of the core is frozen by piping liquid carbon dioxide at ambient temperature through a steel tube from a bottle at the land surface to the drive shoe where it evaporates and expands, cooling the interior surface of the shoe to about $-70^{\circ}$ Celsius. The freezing process takes about 10 minutes. This device was used to collect samples for a study of oil-water-air distributions in unconsolidated sediments at the site of an oil spill near Bemidji, Minnesota. Before freezing was employed, samples of sandy sediments from near the water table sometimes flowed out of the core barrel as the sampler was withdrawn. Freezing the bottom of the core ensured the retention of all material that entered the core barrel and lessened the redistribution of fluids within the core.

${ }^{1}$ U.S. Geological Survey, Menlo Park, Calif. 


\title{
USE OF ${ }^{15} \mathrm{~N}$ TO TRACE MOVEMENT OF NITROGEN FERTILIZER AT A FIELD PLOT
}

\author{
by Dale W. Blevins ${ }^{1}$, Donald H. Wilkison ${ }^{1}$, Steven R. Silva ${ }^{2}$, and Brian P. Kelly ${ }^{1}$
}

A simplified, lower-cost technique for preparation of water samples for nitrogen isotope $\left(\delta^{15} \mathrm{~N}\right)$ analysis of nitrate $\left(\mathrm{NO}_{3}\right)$ is being tested. Anion exchange resins were used to concentrate nitrate in the field and samples were prepared for $\delta^{15} \mathrm{~N}-\mathrm{NO}_{3}$ (ratio of ${ }^{15} \mathrm{~N}$ to ${ }^{14} \mathrm{~N}$ in $\mathrm{NO}_{3}$, relative to atmospheric $\mathrm{N}$, expressed in per mil) analysis using a modification of the Dumas combustion method. Initial test results of the $\delta^{15} \mathrm{~N}-\mathrm{NO}_{3}$ technique indicate that a precision of 0.05 per mil can be achieved. More than 99 percent of nitrate in solution is sorbed onto the resins. Hydrochloric acid was used to elute 95 to 100 percent of the nitrate from the resins. Chloride and organic molecules can interfere with $\delta^{15} \mathrm{~N}-\mathrm{NO}_{3}$ values, but not at concentrations detected at the field plot.

The ${ }^{15} \mathrm{~N}$-labeled fertilizer was applied to a 0.1 -acre field plot in May 1992 to determine the quantity of nitrogen fertilizer reaching ground water. Thirteen percent of the labeled fertilizer was removed from the plot in harvested grain. Soil-gas analyses indicated no significant denitrification of the applied fertilizer. Labeled fertilizer accounted for 34 percent of the nitrate in runoff in the first storm after application. Small quantities of labeled fertilizer were detected 1.5 feet below ground surface 1 month after application, but evapotranspiration prevented further downward movement until November 1992. Labeled fertilizer was detected in shallow wells within 6 days of the first recharge event in November 1992 . The $\delta^{15} \mathrm{~N}-\mathrm{NO}_{3}$ values in deep wells increased 1 month later. Labeled fertilizer accounted for as much as $\mathbf{0 . 7 4}$ milligram per liter of the nitrate in ground water.

${ }^{1}$ U.S. Geological Survey, Independence, MO

${ }^{2}$ U.S. Geological Survey, Menlo Park, CA 


\title{
EFFECTS OF FARMING SYSTEMS ON GROUND-WATER QUALITY AT THE PRINCETON, MINNESOTA MANAGEMENT SYSTEMS EVALUATION AREA, 1991
}

\author{
by Matthew K. Landon ${ }^{1}$, Geoffrey N. Delin ${ }^{1}$, John A. Lamb ${ }^{2}$, Robert H. Dowdy ${ }^{3}$, and James L. Anderson ${ }^{2}$
}

The 65-hectare Management Systems Evaluation Area (MSEA) near Princeton, Minnesota is one of five primary MSEA's in the Midwest Cornbelt. The Princeton MSEA program is a cooperative research effort among the U.S. Department of Agriculture-Agricultural Research Service, the University of Minnesota Soil Science

Department, and the U.S. Geological Survey. The primary program objective is to evaluate the effects of ridge-tillage practices in corn and soybean farming systems on ground-water quality in a sand-plain setting. A sweet-corn and potato farming system is also being evaluated. Analyses of samples collected at the beginning of the study during April 1991 indicated that some contamination of ground water with nitrate nitrogen (nitrate- $\mathrm{N}$ ), atrazine, and atrazine metabolites had already occurred before implementation of the MSEA farming systems.

Chloride in potash fertilizers applied to the MSEA cropped areas in April 1991 was used as a tracer for ground water affected by the MSEA farming systems. Chloride reached ground water beneath all of the cropped areas. Analyses of ground-water samples collected during June, August, and December 1991 and during April 1992 indicated that concentrations of chloride in the upper meter of the saturated zone beneath and downgradient of the cropped areas were 20 to $50 \mathrm{mg} / \mathrm{L}$ (milligrams per liter) compared with background concentrations of 2 to $19 \mathrm{mg} / \mathrm{L}$.

Because the nitrogen and potash fertilizer application rates on the potato-cropped area were 1.4 and 4.5 times greater, respectively, than on the other cropped areas, nitrate- $\mathrm{N}$ and chloride concentrations were greatest beneath the potato-cropped area. Nitrate-N concentrations in the upper meter of the saturated zone beneath the potato-cropped area $(22-47 \mathrm{mg} / \mathrm{L})$ were greater than concentrations measured upgradient $(6-18 \mathrm{mg} / \mathrm{L})$ from the cropped area. Nitrate$\mathrm{N}$ concentrations were similar upgradient, beneath, and downgradient of the other cropped areas. Thus, additions of nitrate-N as a result of MSEA activity were difficult to distinguish from background concentrations. Concentrations of nitrate-N in the saturated zone across the entire MSEA typically decreased from 15 to $25 \mathrm{mg} / \mathrm{L}$ near the water table to 5 to $10 \mathrm{mg} / \mathrm{L}$ two meters below the water table.

Atrazine and atrazine metabolites de-ethylatrazine (DEA) and de-isopropylatrazine (DIA) were detected in 75, 97, and 76 percent, respectively, of the 124 wells sampled at the Princeton MSEA during the four sampling periods from June 1991 through April 1992. The concentrations of these compounds in the saturated zone varied temporally. Atrazine was detected in 51 percent of the 315 ground-water samples collected in concentrations ranging from less than $0.01 \mu \mathrm{g} / \mathrm{L}$ (micrograms per liter) to $0.54 \mu \mathrm{g} / \mathrm{L}$. The median concentration of atrazine was the detection limit of $0.01 \mu \mathrm{g} / \mathrm{L}$. DEA was detected in 74 percent of the samples at concentrations ranging from less than $0.03 \mu \mathrm{g} / \mathrm{L}$ to 1.00 $\mu \mathrm{g} / \mathrm{L}$. The median concentration of DEA was $0.08 \mu \mathrm{g} / \mathrm{L}$. DIA was detected in 10 percent of the samples in concentrations ranging from less than $0.06 \mu \mathrm{g} / \mathrm{L}$ to $0.66 \mu \mathrm{g} / \mathrm{L}$. The median concentration of DIA was less than the detection limit of $0.06 \mu \mathrm{g} / \mathrm{L}$. Alachlor was detected in 2 percent of the samples. Concentrations of DEA in April 1992 increased with depth from less than $0.06 \mu \mathrm{g} / \mathrm{L}$ near the water table to 0.08 to $0.30 \mu \mathrm{g} / \mathrm{L}$ between 1 and $2 \mathrm{~m}$ below the water table. This trend with depth was not noticeable prior to April 1992 and could indicate that water recharging the aquifer beneath the cropped areas during 1991 had lower DEA concentrations than older ground water.

Because some of the applied fertilizers and herbicides and herbicide metabolites existed in shallow ground water at the onset of this study, it is difficult to assess the affects of MSEA farming systems on water quality without additional data collected over several years. None of the detections of herbicides or herbicide metabolites can be conclusively linked to the MSEA farming systems at this time. Because some atrazine and atrazine metabolites were detected in ground water that was recharged through the MSEA cropped areas, however, the possibility that some of these chemicals leached from the MSEA farming systems to ground water cannot be discounted. Use of conservative tracers like chloride and bromide to delineate annual recharge fronts beneath the MSEA cropped areas should make it easier to identify the affects of MSEA farming systems on ground-water quality as older ground water affected by previous farming practices moves horizontally and vertically away from the cropped areas.

\footnotetext{
${ }^{1}$ U.S. Geological Survey, WRD, Mounds View, Minn.

${ }^{2}$ University of Minnesota, Department of Soil Science, St. Paul, Minn.

${ }^{3}$ U.S. Department of Agriculture, Agricultural Research Service, St. Paul, Minn.
} 


\section{Session 7--Research on Agricultural Chemicals in the Midwest II}




\title{
OCCURRENCE, DEPOSITION, AND LONG RANGE TRANSPORT OF HERBICIDES IN PRECIPITATION IN THE MIDWESTERN AND NORTHEASTERN UNITED STATES
}

\author{
Donald A. Goolsby ${ }^{1}$, E. Michael Thurman ${ }^{2}$, Michael L. Pomes ${ }^{2}$, Michael Meyer ${ }^{2}$, and \\ William A. Battaglin ${ }^{1}$
}

\begin{abstract}
Herbicides were detected in precipitation throughout the midwestern and northeastern United States during late spring and summer of 1990 and 1991. During May and June atrazine, alachlor, or both were detected in 60 to 75 percent of weekly accumulations of precipitation collected at 81 sampling sites in 23 States. Atrazine or alachlor were detected in at least one sample from all States, including samples from remote wilderness areas such as Isle Royale in northern Lake Superior. During the remainder of the year, herbicides generally were detected in weekly samples at less than about 20 percent of the sites. Atrazine was the most frequently detected herbicide, followed by alachlor, desethylatrazine, and metolachlor. Herbicide concentrations and frequency of detection were much higher in the Midwest than elsewhere. Precipitation-weighted herbicide concentrations for mid-April through mid-July typically were 0.2 to $0.4 \mu \mathrm{g} / \mathrm{L}$ (micrograms per liter) in the Midwest and weighted concentrations as large as $0.9 \mu \mathrm{g} / \mathrm{L}$ were present at a few sites. Concentrations of 1 to $3 \mu \mathrm{g} / \mathrm{L}$ were measured in a few individual samples representing small amounts of precipitation. Deposition rates for both atrazine and alachlor ranged from more than $200\left(\mu \mathrm{g} / \mathrm{m}^{2}\right) / \mathrm{yr}$ (micrograms per square meter per year) at a few sites in the Midwest to less than $10\left(\mu \mathrm{g} / \mathrm{m}^{2}\right) / \mathrm{yr}$ in the Northeast. These amounts represent less than 1 percent of the atrazine and alachlor applied annually to crops. The geographic pattern of herbicide deposition provides evidence for long-range atmospheric transport.
\end{abstract}

${ }^{1}$ U.S. Geological Survey, Lakewood, Colorado

${ }^{2}$ U.S. Geological Survey, Lawrence, Kansas 


\title{
Chemistry, Degradation, and Transport of Triazine Herbicide Metabolites in Surface Water
}

\author{
by E.M. Thurman, M.S. Mills, and M.T. Meyer
}

\begin{abstract}
Deethylatrazine and deisopropylatrazine are two major metabolites of the triazine herbicides that occur in surface water of the midwestern United States. They may originate from the decomposition of several original parent compounds. Atrazine, the major triazine herbicide used in the Midwest, degrades systematically to both deethylatrazine and deisopropylatrazine with a ratio $\left(D^{2} R\right)$ of approximately 0.40 for runoff water from cornfields. Ground water usually contains only trace concentrations of deisopropylatrazine compared to deethylatrazine because of the more rapid decomposition of deisopropylatrazine in the unsaturated zone. Thus, the $D^{2} R$ may be used to distinguish surface-water runoff from ground water that discharges to surface water. However, other parent herbicides may affect the D2 R. For example, cyanazine may degrade to deisopropylatrazine by the loss of the cyano-isopropyl group. Because cyanazine is the fourth most frequently used herbicide in the Midwest, the $D 2 R$ in surface water often is considerably greater than 0.40 (from 0.60-0.80). Simazine, another parent triazine herbicide, also may degrade to deisopropylatrazine. Simazine is used for weed control along highways and in orchards where considerably larger concentrations are applied. The resulting runoff contains deisopropylatrazine as a major dealkylated degradation product. Propazine, a parent triazine herbicide that is used only occasionally on grain sorghum, degrades to yield the deethylatrazine metabolite. Finally, terbuthylazine, a triazine not marketed in the United States, but used extensively in Europe, also may degrade to deisopropylatrazine via the loss of a t-butyl group. Thus, these parent compounds should be considered when using metabolite ratios as indicators of flow path.
\end{abstract}

1U.S. Geological Survey, Lawrence, KS. 


\title{
Annual Use and Transport of Agricultural Chemicals in the Mississippi River, 1991-92
}

\author{
William A. Battaglin ${ }^{1}$, Donald A. Goolsby ${ }^{1}$, and Richard H. Coupe ${ }^{2}$
}

The presence of agricultural chemicals (herbicides, insecticides, and nutrients) in the Mississippi River and several tributaries follows an annual cycle. Herbicide concentrations are generally highest during periods of storm runoff following application in the spring and early summer. Nitrate concentrations are generally highest in the winter and spring and lower during the summer and fall.

Concentrations and mass transport of agricultural chemicals in rivers are generally related to the amounts of the chemicals used within the river drainage basins. A geographic information system (GIS) was used to analyze relations among county-level estimates of the mass of agricultural chemicals applied (kilograms of active ingredient applied per county) and the annual transport of dissolved chemicals in rivers. Relations were studied for the Mississippi River and several tributaries in the midwestern United States. County-level estimates of herbicide and nitrogen use were developed into a series of GIS data layers and used to estimate the mass of agricultural chemicals used annually within specific drainage basins. Analytical data from periodic water-quality sampling and daily streamflow data were used to estimate the mass of agricultural chemicals transported out of specific drainage basins by rivers. These data sets were used to develop statistical models for estimating annual transport of agricultural chemical as a percentage of estimated annual agricultural chemical use in the basins of the Mississippi River and several tributaries. Results indicated that, in 1991, estimated masses equivalent to about 15 percent of the commercial nitrogen fertilizer, 1.6 percent of the atrazine and cyanazine, 0.8 percent of metolachlor, and 0.2 percent of the alachlor applied in the drainage basins studied were transported out of the basins by rivers.

${ }^{1}$ U.S. Geological Survey, Lakewood, Colorado

${ }^{2}$ U.S. Geological Survey, Urbana, Illinois 


\title{
PESTICIDES IN NEAR-SURFACE AQUIFERS: RESULTS OF THE MIDCONTINENTAL UNITED STATES GROUND-WATER RECONNAISSANCE, $1991-92$
}

by Dana W. Kolpin', Donald A. Goolsby², Diana S. Aga ${ }^{3}$, Jana L. Iverson ${ }^{2}$, and E. Michael Thurman ${ }^{3}$

\begin{abstract}
Selected pesticides and metabolites were examined in near-surface aquifers in the corn- and soybean-producing region of the midcontinental United States to determine their hydrogeologic, spatial, and seasonal distribution. At least one herbicide or atrazine metabolite was detected in 28.4 percent of the 303 wells sampled during the spring and late summer of 1991. During 1991, deethylatrazine was the most frequently detected compound followed by atrazine, deisopropylatrazine, and prometon. No herbicide concentration exceeded the U.S. Environmental Protection Agency's maximum contaminant levels for drinking water. During 1991, the highest frequency of herbicide detection was in the western part of the study region and lowest frequency of detection was in the eastern part of the study region.

Unconsolidated aquifers were found to be more susceptible to herbicide contamination than bedrock aquifers on the basis of results of the 1991 study. During the summer of 1992, additional water samples were collected from 101 wells to examine the occurrence of agricultural chemicals not analyzed during the previous year. Water from 62 percent of the resampled wells had detectable concentrations of either a pesticide or pesticide metabolite; 27 different compounds were detected. During the 1992 study, five of the six most frequently detected compounds were herbicide metabolites.
\end{abstract}

\footnotetext{
${ }^{1}$ U.S. Geological Survey, Iowa City, Iowa

2 U.S. Geological Survey, Denver, Colorado

${ }^{3}$ U.S. Geological Survey, Lawrence, Kansas
} 


\title{
COMPARISON OF SIMULATED AND \\ OBSERVED MOVEMENT OF BANK-STORAGE WATER \\ ADJACENT TO THE CEDAR RIVER, IOWA
}

\author{
By Paul J. Squillace ${ }^{1}$ and David W. Pollock ${ }^{2}$
}

U.S. Geological Survey

\begin{abstract}
A ground-water flow model was constructed to describe quantitatively the movement of bank-storage water in an alluvial aquifer adjacent to the Cedar River, Iowa, during March 7-April 17, 1990, at the Palisades study area. The results from this two-dimensional model were compared to hydrologic and water-chemistry data. Hydrologic data consisted of 744 daily ground-water-level measurements made in 30 wells during March 8-April 5, 1990. These 744 measurements were used for model calibration and for comparing measured and simulated hydraulic heads and gradients. Water-chemistry data indicate that bank-storage water had a lower specific conductance and higher concentration of atrazine compared to the ambient ground water. Analysis of water chemistry and model results indicate that bank-storage water moved about 30 meters into the aquifer at a depth of 6 meters below land surface. The model also showed that 70 percent of the total bank-storage water moved through the river bottom while the remaining 30 percent moved laterally through the riverbank. The flux of bank storage-water both into and out of the river bottom is largest near the river's edge and decreases substantially with distance from the river's edge to the center of the river. The model showed that it would take about 5 weeks for bank-storage water to discharge from the alluvial aquifer after the peak river stage.
\end{abstract}

\footnotetext{
${ }^{1}$ U. S. Geological Survey, Iowa City, IA

2 U. S. Geological Survey, Reston, VA
} 


\title{
DETERMINING THE RELATIVE AGE, TRANSPORT, AND THREE-DIMENSIONAL DISTRIBUTION OF ATRAZINE IN A RESERVOIR USING IMMUNOASSAY
}

\author{
by James D. Fallon ${ }^{1}$ and E.M. Thurman ${ }^{1}$
}

\begin{abstract}
The age, transport, and distribution of atrazine in a reservoir were determined by enzyme-linked immunosorbent assay. A pulse of stormwater runoff containing atrazine concentrations as much as nine times greater than the U.S. Environmental Protection Agency Maximum Contaminant Level (MCL) for drinking water (the MCL for atrazine is based on an annual average concentration of 3.0 micrograms per liter) was monitored as it moved through Perry Lake, northeastern Kansas, during the 1992 growing season. The drainage basin of Perry Lake is the first Pesticide Management Area designated by the State of Kansas. The leading edge of the pulse marked the boundary and mixing zone between atrazine applied in previous years and freshly applied atrazine. Deethylatrazineto-atrazine ratios (DAR) further defined the relative age of atrazine in the reservoir. Runoff entering the reservoir immediately after herbicide application was identified by its small DAR values $(0.095$ to 0.134$)$. Water with increasing DAR values $(0.135$ to 0.254$)$ entered the reservoir as the year progressed and gradually displaced water with smaller DAR values. Four hundred and twenty (420) samples from four detailed reservoir surveys (pre-application, post-application, summer, and autumn) were analyzed by immunoassay to determine the distribution of herbicide concentrations in the reservoir. Also, weekly samples were collected from four fixed sites located upstream, within, and downstream from the reservoir. One hundred (100) of these samples were analyzed by gas chromatography/mass spectrometry to confirm immunoassay results and to determine deethylatrazine and deisopropylatrazine concentrations. A combination of immunoassay and DAR values could prove useful in developing reservoir-release strategies to mitigate atrazine concentrations in reservoirs and their outflows.
\end{abstract}

1 U.S. Geological Survey, Lawrence, Kansas. 


\title{
Session 8--Poster Presentations
}

\section{Picatinny}

\author{
Methods and Techniques
}

\section{Research on Agricultural Chemicals in the Midwest}

\section{Unsaturated Zone Research}




\section{DESORPTION OF TRICHLOROETHYLENE FROM AQUIFER SEDIMENTS \\ AT PICATINNY ARSENAL, NEW JERSEY}

by David Koller ${ }^{1}$, Thomas E. Imbrigiotta ${ }^{1}$, Arthur L. Baehr', and James A. Smith ${ }^{2}$

Desorption of trichloroethylene (TCE) from contaminated aquifer sediments is postulated to be a continuing source of this contaminant to ground water downgradient from the site of a former metal-plating/degreasing operation at Picatinny Arsenal, New Jersey. Flow-through columns were constructed with sediments from four sites within the TCE plume to determine whether TCE desorption was occurring and, if so, at what rate. Results of the column experiments with contaminated sediments indicate that TCE desorption is occurring at all sites tested. Desorption in these columns appeared to occur in two stages--an initial rapid stage (days to weeks) during which 1 to 10 percent of the total sorbed mass of TCE is released, followed by a slow stage (months to years) during which the remaining 90 to 99 percent is desorbed. Results of a column experiment with sediment artificially contaminated in the laboratory for only 5 days showed the same two-stage desorption, but 65 to 70 percent of the sorbed TCE was desorbed in the initial, rapid stage, and the remaining 30 to 35 percent was desorbed in the slow stage.

A one-dimensional model was developed to determine the desorption rates by simulating the desorption measurements from the column experiments. The model simulates the initial, rapid-stage desorption as an equilibrium process, and simulates the second, slower stage desorption as a kinetic process. Results of model simulations compared well with the column data. Modelcalculated long-term (slow-stage) desorption rates of TCE from Picatinny Arsenal soils ranged from 0.5 to $2.5 \times 10^{-} 8$ per second.

${ }^{1}$ U.S. Geological Survey, 810 Bear Tavern Road, Suite 206, West Trenton, NJ . 08628

${ }^{2}$ Department of Civil Engineering and Applied Mechanics, University of Virginia, Charlottesville, VA 22903-2442 


\section{EFFECT OF AIR DRYING ON SOLVENT EXTRACTION OF TRICHLOROETHYLENE-CONTAMINATED SOIL}

by David Koller ${ }^{1}$, Thomas E. Imbrigiotta ${ }^{1}$, and James A. Smith ${ }^{2}$

The effect of air drying trichloroethylene (TCE)-contaminated soils prior to extraction with methanol to determine the concentrations of sorbed TCE was investigated. Saturated-aquifer soil and ground-water samples were collected at five locations within a TCE plume at Picatinny Arsenal, New Jersey. Each soil sample was split into two portions; one portion underwent extraction while wet and the other underwent extraction after being air dried overnight. Concentrations of TCE in the wet soils were corrected for TCE in the soil moisture by using results of analyses of the ground-water samples. Comparison of the extraction results for air-dried and wet soils showed that, for four of the five samples, the concentration of sorbed TCE in the air-dried portion was higher than or not significantly different from that in the wet portion. In addition, the precision of the extraction results for air-dried soils was not significantly different from that obtained for wet soils.

${ }^{1}$ U.S. Geological Survey, 810 Bear Tavern Road, Suite 206, West Trenton, NJ 08628

${ }^{2}$ Department of Civil Engineering and Applied Mechnaics, University of Virginia, Charlottesville, VA 22903-2442 
IN SITU BIOTRANSFORMATION OF TRICHLOROETHYLENE AND

CIS-1,2-DICHLOROETHYLENE AT PICATINNY ARSENAL, NEW JERSEY

by Theodore A. Ehlke ${ }^{1}$, Barbara H. Wilson ${ }^{2}$, John T. Wilson ${ }^{3}$, and Thomas E. Imbrigiotta ${ }^{1}$

Biotransformation of trichloroethylene (TCE) and cis-1,2-dichloroethylene (cis-DCE) was estimated within a part of the unconfined aquifer at Picatinny Arsenal, New Jersey, that is contaminated with chlorinated solvents. The first-order in situ biotransformation rate for TCE was estimated to range from about 0.001 per week to about 0.05 per week. The in situ removal rates generally are more rapid than the biotransformation rates that were measured previously in the laboratory in soil cores collected at the arsenal.

In situ biotransformation was estimated to occur more slowly for cis-DCE than TCE. The first-order biotransformation rate for cis-DCE ranged from about 0.01 per week to 0.03 per week. Long-term concentrations of TCE and cis-DCE in ground-water at one location indicate that TCE concentration probably was not the major determining factor limiting the alteration of TCE to cis-DCE in ground water.

\footnotetext{
${ }^{1}$ U.S. Geological Survey, 810 Bear Tavern Road, Suite 206, West Trenton, New Jersey 08628

${ }^{2}$ Dynamac Corporation, Robert S. Kerr Environmental Research Laboratory, Kerr Lab Road, Ada, Oklahoma 74820

${ }^{3}$ U.S. Environmental Protection Agency, Robert S. Kerr Environmental Research Laboratory, Kerr Lab Road, Ada, Oklahoma 74820
} 


\title{
Surfactant-Enhanced Remediation of Ground Water at Picatinny Arsenal, New Jersey
}

\author{
by James A. Smith ${ }^{1}$ and James J. Deitsch ${ }^{1}$
}

The efficiency of pump-and-treat remedial systems is limited by the slow, kinetic mass transfer of organic contaminants from soil to water. The scope of this research is to determine whether the addition of the nonionic surfactant, Triton X-100, to the aqueous phase can artificially increase the rate of trichloroethene (TCE) mass transfer from soil to water at Picatinny Arsenal. The rate of TCE mass transfer (desorption) from soil to water is modeled as the product of a mass-transfer coefficient and a concentration gradient. Laboratory experiments were conducted using continuous-flow stirred tank reactors (CFSTR's), with and without Triton X-100, to study the effect of the surfactant on the rate of desorption of TCE from soil to water. Preliminary results indicate that the rate of desorption is increased by the presence of Triton X-100 in the aqueous phase. Two possible mechanisms are responsible for the increased desorption rate: First, the addition of Triton X-100 above its critical micelle concentration can increase the apparent water solubility of TCE and thus increase the concentration gradient between the sorbed and aqueous phases. Second, Triton X-100 can increase the mass-transfer coefficient. Future experiments are planned to determine the precise mechanism affecting the rate of desorption.

${ }^{1}$ Dept. of Civil Engineering, Univ. of Virginia, Charlottesville, VA 
Determination of Surface Area of Soil Components by Sorption of Nitrogen and

Ethylene Glycol Monoethyl Ether Vapors and Evaluation of

Adsorption, Partition and Cation Solvation Processes

Cary T. Chiou ${ }^{1}$ and David W. Rutherford ${ }^{1}$

The vapor uptake isotherms of nitrogen and ethylene glycol monoethyl ether (EGME) were determined for soil and soil components. The cross sectional area of EGME was determined to be $40.0 \times 10^{-20} \mathrm{~m}^{2}$ by comparing adsorption isotherms on reference surface area standards. For samples where EGME does not penetrate into the solid (Ottawa Sand, hematite, aluminum oxide, synthetic hydrous iron oxide, and kaolinite), the EGME and nitrogen isotherms show consistent surface uptake and the EGME isotherm can be reasonably estimated from the nitrogen isotherm by multiplying the nitrogen uptake by a factor of 1.3 to account for different molecular area and molecular weight. For other samples where the EGME can penetrate into the solid (peat, $\mathrm{Ca}$ montmorillonite, and illite), the total uptake can be resolved to surface adsorption, partition into soil organic matter, and/or cation solvation. For peat, the nitrogen uptake is very small, resulting in a surface area of 1.3 square meters per gram ; uptake of EGME on peat is a large and linear, which is indicative of large bulk solubility of EGME in soil organic matter (190 miligrams per gram). For Ca-montmorillonite, the resulting cation solvation isotherm shows a stoichiometric interaction of about 4 EGME molecules per exchangeable $\mathrm{Ca}$ ion. Exchange of organic cations for metal ions in montmorillonite sharply decreases the cation solvation effect of EGME. This cation exchange may result in a higher surface area of the clay due to opening of interlayer surfaces.

1 U.S. Geological Survey, Box 25046, MS 408, Denver Federal Center, Denver, CO 80225 


\title{
MEASUREMENT OF CONCENTRATIONS OF ALACHLOR AND ITS ETHANESULFONIC ACID METABOLITE IN WATER BY SOLID-PHASE EXTRACTION AND ENZYME-LINKED IMMUNOSORBENT ASSAY
}

\author{
by
}

\author{
Diana S. Aga ${ }^{1}$, E. Michael Thurman ${ }^{1}$, and Michael L.Pomes ${ }^{1}$
}

\begin{abstract}
Solid-phase extraction (SPE) and enzyme-linked immunosorbent assay (ELISA) were combined for the trace analysis of 2-chloro-2',6'-diethyl-N-(methoxymethyl)acetanilide (alachlor) and 2-[(2,6-diethylphenyl)(methoxymethyl)amino-]-2-oxoethanesulfonic acid (ESA, a major soil metabolite of alachlor). The anti-alachlor antibody reacted not only with alachlor but also with ESA, which produced false-positive immunoassay detections of alachlor in natural water samples. The combination of SPE with ELISA effectively separates and determines both parent and metabolite compounds; thus, the same antibody may be used for two ELISA methods. Alachlor and ESA were isolated from water by SPE on $\mathrm{C}_{18}$ resin and were eluted sequentially with ethyl acetate and methanol. The separation involves the difference in solubility of the ionic sulfonic acid in ethyl acetate and methanol. The SPE-ELISA method has a detection limit of $0.01 \mu \mathrm{g} / \mathrm{L}$ (micrograms per liter) for alachlor and $0.05 \mu \mathrm{g} / \mathrm{L}$ for ESA with a precision of \pm 10 percent. Analyses of surface-water and ground-water samples were confirmed by high-performance liquid chromatography with photodiode-array detection and gas chromatography/mass spectrometry. Results showed widespread presence of ESA in surface water and ground water of the midwestern United States in concentrations of 0.10 to greater than $10 \mu \mathrm{g} / \mathrm{L}$.
\end{abstract}

1 U.S. Geological Survey, 4821 Quail Crest Place, Lawrence, KS 66049. 


\title{
ISOCRATIC SEPARATION OF ALACHLOR ETHANESULFONIC ACID, ALACHLOR OXOACETIC ACID, AND HYDROXYATRAZINE BY REVERSED- PHASE LIQUID CHROMATOGRAPHY
}

by Michael L. Pomes ${ }^{1}$, Douglas F. Holub ${ }^{1}$, Diana S. Aga, ${ }^{1}$ and E.M. Thurman ${ }^{1}$

\begin{abstract}
The polar nature of two alachlor metabolites, alachlor ethanesulfonic acid and alachlor oxoacetic acid, makes their detection by gas chromatography/mass spectrometry impossible without derivatization. Enzyme-linked immunosorbent-assay techniques cannot distinguish alachlor metabolites from alachlor; thus, reversed-phase highperformance liquid chromatography with photodiode-array detection is required for the separation and spectral detection of these analytes. Use of an isocratic, methanol/10 millimolar sodium phosphate dibasic buffer mixture as the mobile phase with reversedphase (C-18) high-performance liquid chromatography allows for the separation and quantification of alachlor ethanesulfonic acid, alachlor oxoacetic acid, and hydroxyatrazine at concentrations greater than or equal to 0.10 micrograms per liter in 100-milliliter water samples. The buffer in the methanol mixture provides cations that ion pair with the alachlor metabolite anions to decrease polarity and promote nonpolar interactions between the analytes and the reversed-phase column. Enhanced chromatographic resolution results from injecting samples in a matrix that contains less methanol than the mobile phase. The disparity between the methanol content of the sample matrix and the mobile phase focuses the analytes at the head of the chromatographic column to produce sharper peaks because the analytes are less soluble in the sample matrix than in the mobile phase. Results by reversed-phase high-performance liquid chromatography show that one can detect alachlor ethanesulfonic acid in surface water, along with lesser concentrations of alachlor oxoacetic acid and hydroxyatrazine.
\end{abstract}

1 U.S. Geological Survey, Lawrence, Ks. 


\title{
Atrazine Transport and Degradation in a Pristine Watershed:
}

\section{The Fate of Atrazine Deposited by Precipitation}

\author{
by Aron E. Cromwell and E. Michael Thurman ${ }^{1}$
}

\begin{abstract}
Atrazine used in agricultural areas is being transported atmospherically and deposited by precipitation onto pristine watersheds. The fate of atrazine was studied at Isle Royale National Park, an island park located in Lake Superior on the United StatesCanadian border. Samples of rainfall, soil water, surface water, and soils were analyzed by combining solid-phase extraction (SPE) with enzyme-linked immunosorbent assay (ELISA). This SPE-ELISA combination enabled the field analysis of water samples in which the concentrations of atrazine were as small as $5 \mathrm{ng} / \mathrm{L}$ (nanograms per liter). The SPE-ELISA results were confirmed using gas chromatography/mass spectrometry (GC/MS) with isotope dilution. Maximum atrazine concentrations in rainfall occurred in late spring, approaching the U.S. Environmental Protection Agency Maximum Contaminant Level (MCL) for drinking water of 3.0 micrograms per liter. By midsummer, rainfall concentrations of atrazine had decreased to less than $5 \mathrm{ng} / \mathrm{L}$. Atrazine was found in small concentrations in water from all lakes that were sampled. Field data indicate that atrazine degrades rapidly in soil environments but more slowly in aquatic environments. This slow degradation rate in water has important implications for the quality of lakes in pristine areas receiving atrazine-contaminated rainfall because of the potential for accumulation of atrazine in the ecosystem.
\end{abstract}

1U.S. Geological Survey, Lawrence, KS. 


\title{
PERSISTENCE OF HERBICIDES IN SELECTED RESERVOIRS IN THE MIDWESTERN UNITED STATES: SOME PRELIMINARY RESULTS
}

\author{
Donald A. Goolsby ${ }^{1}$, William A. Battaglin ${ }^{1}$, James D. Fallon ${ }^{2}$, Diana S. Aga ${ }^{2}$, \\ Dana W. Kolpin ${ }^{3}$, and E. Michael Thurman ${ }^{2}$
}

\begin{abstract}
Preliminary results from a study of herbicides in 76 midwestern reservoirs show that some herbicides and metabolites of atrazine and alachlor are detected more frequently throughout the year in reservoirs than in streams. Except for a short period after application to cropland, herbicide concentrations also are generally higher in reservoirs than in streams. Herbicides or their metabolites were detected in 82 to 92 percent of the reservoirs sampled during four periods from late April through early November 1992. Atrazine was detected most frequently and in highest concentrations, followed by an alachlor metabolite (alachlor ethanesulfonic acid), and two atrazine metabolites (desethylatrazine and deisopropylatrazine). The longer persistence of some herbicides and metabolites in reservoirs than streams is attributed to longer half lives for these compounds in the water column than in the soil where concentrations of organic matter and microorganisms are much higher and contribute to rapid biodegradation of herbicides. A second contributing factor is long-term storage of water in reservoirs that originates as spring and summer storm runoff from cropland and which contains high concentrations of herbicides.
\end{abstract}

${ }^{1}$ U.S. Geological Survey, Lakewood, Colorado

${ }^{2}$ U.S: Geological Survey, Lawrence, Kansas

${ }^{3}$ U.S. Geological Survey, Iowa City, Iowa 


\section{RECONNAISSANCE DATA FOR SELECTED HERBICIDES}

AND TWO METABOLITES IN SURFACE WATER

OF THE MIDWESTERN UNITED STATES:CHEMICAL ANALYSIS BY

IMMUNOASSAY AND GAS

CHROMATOGRAPHY/MASS SPECTROMETRY

by Elisabeth A. Scribner, E. Michael Thurman ${ }^{1}$, and Donald A. Goolsby ${ }^{2}$

\section{ABSTRACT}

Water-quality data were collected from 147 rivers and streams during 1989-90 for an assessment of selected preemergent herbicides and two metabolites in 10 Midwestern States. All water samples were collected by depthintegrating techniques at three to five locations across each stream. Sites were sampled three times in 1989: before application of herbicides, during the first major runoff after application of herbicides, and in the fall during a low-flow period when most of the streamflow was derived from ground water. About 50 sites were selected by a stratified random procedure and resampled for both pre-and postapplication herbicide concentrations in 1990 to verify the 1989 analytical results. Laboratory analyses consisted of enzyme-linked immunosorbent assay (ELISA) with confirmation by gas chromatography/mass spectrometry (GC/MS). The data have been useful in (1) studying herbicide transport, (2) comparing the spatial distribution of the post-application concentrations of 11 herbicides and 2 metabolites (deethylatrazine and deisopropylatrazine) in streams and rivers at a regional scale, (3) examining the annual persistence of herbicides and their metabolites in surface water, and (4) assessing whether the two atrazine metabolites can be used as indicators of surface- and ground-water interaction.

1 U.S. Geological Survey, Lawrence, Kans.

2 U.S. Geological Survey, Denver, Colo. 


\title{
RELATION OF NITRATE CONCENTRATIONS IN SURFACE WATER TO LAND
}

\section{USE IN THE UPPER-MIDWESTERN UNITED STATES, 1989-90}

\author{
by David K. Mueller ${ }^{1}$, Barbara C. Ruddy ${ }^{1}$, and William A. Battaglin ${ }^{1}$
}

As part of a study on contamination from agricultural chemicals, nitrate data were collected during several synoptic surveys at a large number of surface-water sites in 10 Midwestern states during 1989-90. These data were analyzed using logistic regression to relate discrete categories of nitrate concentrations to land use in the drainage basins upstream from the sampling sites. The nitrate data were divided into three categories representing background concentrations, elevated concentrations, and concentrations that exceeded the U.S. Environmental Protection Agency maximum contaminant level for drinking water. Land-use data were derived from spatial-digital data available from several sources in national data bases. 'The explanatory variables selected for the best-fit model were percentile of streamflow at the time of sampling, acreage of the basin in corn, acreage in soybeans, density of cattle, and population density. All these variables have qualitative relations to nitrate sources, mobilization, or transport. Classification of nitrate categories from this model was 80 percent accurate in comparison to observed categories. The accuracy of the model was better for classification into categories that represented lower concentrations; however, incorrect classifications were not biased either high or low. Results from this study indicate that land-use data can be useful in analyses of water-quality conditions in large regions and that logistic regression is a valuable technique for use in such analyses.

${ }^{1}$ U.S. Geological Survey, Lakewood, CO 
by G.P. Johnson ${ }^{1}$ and R.H. Coupe ${ }^{1}$

The Sangamon River, located in east-central Illinois, drains some of the most intensively used agricultural land in the Midwest. Effects of agricultural practices in the drainage basin on stream-water quality were investigated by collecting surface-water samples from April 1991 through March 1992 at Monticello, Illinois. Samples were analyzed for concentrations of selected herbicides and nitrate. Total load was calculated and compared to estimated application totals of each compound in the drainage basin above Monticello.

During the study period, 1,607 pounds of atrazine were transported by the river; this mass represents 1.4 percent of the total annual application of 113,700 pounds. The river transported 669 pounds of cyanazine--a mass equal to 1.6 percent of the total annual application of 41,900 pounds. About 353 pounds of alachlor were transported by the river $(0.31$ percent of the 112,300 pounds applied). About 12,100 tons of nitrogen fertilizer were applied, and 3,393 tons of nitrate as nitrogen were transported by the river (28 percent of the total amount applied). However, other natural and human-derived sources of nitrate could have contributed to this total load.

The timing of chemical application and the quantity of rainfall and runoff after herbicide application affected the concentrations. Herbicide concentrations were highest in early spring during storms immediately following application. Peak concentrations for atrazine, cyanazine, and alachlor occurred in May; these concentrations were 21, 16 , and 8.8 micrograms per liter, respectively. Nitrate concentrations were at or above the U.S. Environmental Protection Agency's maximum contaminant level of 10 milligrams per liter from the beginning of the study until June 11, 1991. Nitrate concentrations remained less than the maximum contaminant level until November 1991.

If U.S. Geological Survey, Urbana, Illinois 


\title{
THE DEGRADATION AND TRANSPORT OF CYANAZINE METABOLITES IN SURFACE WATER OF THE MIDWESTERN UNITED STATES
}

\author{
M. T. Meyer and E. M. Thurman 1
}

\begin{abstract}
Cyanazine was detected in 71 percent, cyanazine amide in 59 percent, deethylcyanazine in 32 percent, and deisopropylatrazine in 52 percent of the samples collected during the first storm runoff after herbicide application in a reconnaissance study of stream water from 122 basins in a 10-State area in the midwestern United States in 1989. Furthermore, these compounds were detected in as many as 30 percent of the samples collected in the spring before planting and in the fall of the year during low streamflow. Analysis of samples collected from several stream sites during storm-runoff throughout the spring and early summer of 1990 indicate that cyanazine degrades to deisopropylatrazine and that the ratio of deisopropylatrazine-to-deethylatrazine $\left(D^{2} R\right)$ is an indicator of the amount of cyanazine relative to atrazine that is used in the basin.
\end{abstract}

1 U.S. Geological Survey, 4821 Quail Crest Place, Lawrence, KS 66049. 


\title{
TEMPORAL DISTRIBUTIONS OF HERBICIDE AND NITRITE- NITRATE CONCENTRATIONS AND LOADS IN THE WEST FORK OF THE BIG BLUE RIVER, NEBRASKA, 1990 AND 1991-92
}

by

A. D. Druliner, D. A. Goolsby, and M. Meyer

\begin{abstract}
The West Fork of the Big Blue River in Nebraska drains a relatively flat basin of about 1,200 square miles in which the dominant land use is rowcrop agriculture. From April through July 1990 and April 1991 through March 1992 water samples were collected from the West Fork of the Big Blue River and analyzed principally for concentrations of selected herbicides, nitrite-nitrate, and suspended sediment. The purpose of the investigation was to determine the occurrence, temporal distribution, and persistence of selected herbicides and nitrite-nitrate in surface water within the West Fork of the Big Blue River Basin and to determine the effects of agricultural practices on the concentrations of these constituents.

Atrazine, alachlor, metolachlor, and cyanazine were the herbicides most commonly detected and present in the largest concentrations in the West Fork of the Big Blue River. Large concentrations of these herbicides were present in the river during the first major runoff events after spring chemical application in the fields. The magnitude of the concentrations diminished with successive runoff events. The maximum observed concentrations of the four herbicides were 116, 43, 26, and 8.6 micrograms per liter, respectively. Persistent concentrations of atrazine and some of its daughter products in base flow indicate that ground water is contributing atrazine to the river. On the basis of estimated herbicide application and estimated herbicide loads in the river in 1990 and 1991-92, about 0.4 to 1.3 percent of the total amount of herbicides applied are transported annually in the West Fork of the Big Blue River. The 3- to 4-fold increase in concentrations and loads of selected herbicides from the 1990 to 1991-92 sampling periods probably reflect the timing of chemical application and periods of major precipitation .
\end{abstract}




\title{
PREDICTION OF NITRATE-NITROGEN AND ATRAZINE CONTAMINATION IN THE HIGH PLAINS AQUIFER IN NEBRASKA
}

by

\author{
A.D. Druliner ${ }^{1}$ and T.S. McGrath ${ }^{1}$
}

\begin{abstract}
Three statistical models, developed through the Toxic-Waste--Ground-Water Contamination Program of the U.S. Geological Survey, were used to predict the concentrations of nitrate-nitrogen and atrazine and the probability of atrazine detections in ground water in the High Plains aquifer in Buffalo and Hall counties, south-central Nebraska. The models use a combination of hydrochemical, hydrologic, land-use, and soils explanatory variables, andARC/ INFO techniques to generate maps showing predicted concentrations of the selected contaminants. Confirmational testing of the models and comparison of maps of predicted concentrations to maps of observed concentrations indicate that the statistical models are reasonable predictors of nitrate-nitrogen and atrazine concentrations in ground water of the High Plains aquifer in south-central Nebraska.
\end{abstract}

${ }^{1}$ U.S. Geological Survey, Lincoln, Ne 


\title{
FATE OF ALACHLOR, ATRAZINE, AND BROMIDE IN A CORN PLOT NEAR TOPEKA, KANSAS
}

\author{
by D.A. Eckhardt ${ }^{1}$, R.J. Wagenet ${ }^{2}$, E.M. Thurman ${ }^{3}$, and P.L. Barnes ${ }^{4}$
}

In April 1991, a bromide tracer and the herbicides atrazine and alachlor were applied to a 0.75 -ha field plot of Eudora silt loam in the Kansas River Valley near Topeka, Kansas. The chemicals were immediately disked into the top $7.5 \mathrm{~cm}$ of soil, and the plot was planted with corn. Composite soil cores were collected from 12 contiguous cells in the plot, each $15 \mathrm{~m}$ by $15 \mathrm{~m}$, at $15-\mathrm{cm}$ depth intervals to $90 \mathrm{~cm}$. Cores were collected immediately after application, then after 30 , 60 , and 120 days. Mean atrazine losses from the soil profile, relative to the immediate postapplication core results, were 75 percent at day 30, 92 percent at day 60, and 96 percent at day 120 . Mean alachlor losses were 93 percent at day 30,99 percent at day 60, and nearly 100 percent by day 120 . The ratio of desethylatrazine metabolite to atrazine concentrations steadily increased in the top 15-cm soil layer during the 120-day period. An analysis of the soil-water budget and bromide distribution in the soil profile indicates that downward movement of the chemicals was restricted by a lack of significant downward soil-water flux during the growing season, when evapotranspiration was greatest. Loss of the herbicides from the soil profile is attributed mainly to degradation and transformation, and loss of bromide is attributed mainly to uptake by the crop. Low but persistent herbicide concentrations 120 days after application indicate that herbicide half lives are not constant and that herbicide residues could be tightly bound within solid-phase organic carbon and unavailable for biotic degradation.

\footnotetext{
${ }^{1}$ U.S. Geological Survey, Ithaca, NY

${ }^{2}$ Cornell University, Ithaca, NY

${ }^{3}$ U.S. Geological Survey, Lawrence, KS

${ }^{4}$ Kansas State University, Manhattan, KS
} 


\title{
EFFECTS OF TOPOGRAPHY ON THE TRANSPORT OF AGRICULTURAL CHEMICALS
}

NEAR PRINCETON, MINNESOTA, 1992

by Geoffrey N. Delin and Matthew K. Landon ${ }^{1}$

\begin{abstract}
In 1991, the U.S. Geological Survey (USGS), with funding from the USGS Toxic Substances Hydrology Program, began studying the movement of water and agricultural chemicals at the Management Systems Evaluation Area (MSEA) near Princeton, Minnesota. The research is being conducted in a topographically low (lowland) site and a topographically high (upland) site within the northernmost cropped area at the 65-hectare Princeton MSEA. The sites are about $78 \mathrm{~m}$ (meters) apart and with a difference in land-surface elevation of 1.4 meters. Soils in the upper meter at both the upland and lowland sites are similar and are composed of about 95 percent sand and 5 percent silt and clay. The grain size is coarser between the 1.0 - and $2.0-\mathrm{m}$ depths at the lowland site than at the upland site, however. Total organic carbon in the upper $20 \mathrm{~cm}$ of topsoil is about 1.0 percent at the lowland site and about 0.6 percent at the upland site. Water sampling and monitoring equipment were installed at the upland and lowland sites following a dye-tracing and trenching study that was conducted to identify zones of preferential and retarded water movement and to collect soil samples from the unsaturated-zone.

Infiltration tests were conducted during 1992 at the upland and lowland sites following selected precipitation events or by the application of $2.5 \mathrm{~cm}$ of water from a linear-move sprinkler irrigation system. The movement of wetting fronts through the unsaturated zone to the water table were evaluated using time-domain reflectometry. Water samples were collected from suction lysimeters as the wetting front passed a given lysimeter elevation, and from water-table wells after the wetting front reached the saturated zone.

Wetting fronts typically penetrated deeper into the unsaturated zone at the lowland site than at the upland site during 1992. In addition, the total flux of water into the soil at the lowland site was greater than at the upland site. Following application of about $8 \mathrm{~cm}$ of water beginning June 29,1992 , for example, recharge through the unsaturated zone was about $1.0 \mathrm{~cm}$ at the lowland site compared to about $0.5 \mathrm{~cm}$ at the upland site, based on hydrograph analysis. For this recharge event, the estimated fluxes of nitrate-nitrogen and atrazine through the unsaturated zone to the water table at the lowland site were 3.5 and 5 times greater, respectively, than the fluxes at the upland site. Differences in the movement of wetting fronts, agricultural chemicals, and tracers at the upland and lowland sites likely resulted from a combination of factors including differences in soil organic matter, grain size, porosity, sedimentary heterogeneities, antecedent moisture conditions, and topographic relief. Possible mechanisms that could cause focused recharge of water and agricultural chemicals at the lowland site include surface runoff and iron-rich layers that form a barrier to vertical water movement through the unsaturated zone at the upland site.
\end{abstract}

${ }^{1}$ U.S. Geological Survey, WRD, Mounds View, Minn. 


\title{
SPATLAL VARIABILITY OF UNSATURATED-ZONE PROPERTIES IN RELATION
}

\section{TO TOPOGRAPHY IN A SAND-PLAIN SETTING NEAR PRINCETON, MINNESOTA}

\author{
by Geoffrey N. Delin ${ }^{1}$, Matthew K. Landon ${ }^{1}$, Richard W. Healy ${ }^{2}$, and Harold W. Olsen ${ }^{3}$
}

\begin{abstract}
The spatial distribution of preferential flowpaths and unsaturated-zone properties in two topographic settings were determined from a dye-tracing and trenching study done at the Management Systems Evaluation Area (MSEA) near Princeton, Minnesota. The topographic settings are upland and lowland sites about $78 \mathrm{~m}$ (meters) apart that differ in elevation by $1.4 \mathrm{~m}$. A 3 percent solution of rhodamine-WT dye was applied uniformly as a tracer to a $3.5 \mathrm{~m}$ by $6 \mathrm{~m}$ area at both sites at 10-day intervals from July 5 through September 13, 1991. After application of the dye, a 3-m by $2-\mathrm{m}$ trench was dug to a depth of $2 \mathrm{~m}$ in the middle of each dye-application area to locate the dye and to collect soil samples.

Water samples were collected periodically from a multilevel piezometer, located $2.5 \mathrm{~m}$ horizontally downgradient of each dye-application area, to estimate the time-of-travel of recharge water through the unsaturated zone. The dye was first detected in ground water about 100 days after application. On the basis of average groundwater velocity at the Princeton MSEA of $10 \mathrm{~cm} / \mathrm{d}$ (centimeters per day), the transport velocity of dye through the unsaturated zone was calculated to be $3.7 \mathrm{~cm} / \mathrm{d}$ at the lowland site and $5.3 \mathrm{~cm} / \mathrm{d}$ at the upland site. The dye moved $2 \mathrm{~m}$ vertically through the saturated zone over a horizontal distance of about $9 \mathrm{~m}$, whereas a steady-state groundwater-flow model predicted less than $0.2 \mathrm{~m}$ of vertical movement.

A total of about 450 soil samples were collected from the sides and bottom of the trenches for analyses of bulk density, dye fluorescence, grain-size distribution, hydraulic conductivity, moisture-retention characteristics, organic-carbon content, and volumetric moisture content. The distribution of dye through the unsaturated zone was highly variable at the upland and lowland sites. Dye movement was greatest beneath the furrows and least beneath the corn rows. Preliminary results indicate the dye moved preferentially in response to tillage patterns (com rows and furrows), microtopography, presence of plant roots, differences in total organic carbon, and coarser-grained heterogeneities in the unsaturated zone. Visible dye distriburion did not correlate strongly with bulk density, saturated hydraulic conductivity, moisture-retention characteristics, and volumetric moisture content.
\end{abstract}

${ }^{1}$ U.S. Geological Survey, WRD, Mounds View, Minn.

${ }^{2}$ U.S. Geological Survey, WRD, Lakewood, Colo.

${ }^{3}$ U.S. Geological Survey, GD, Golden, Colo. 


\title{
Geochemistry of Nitrogen in a Farmed Watershed near Princeton, Minnesota
}

\author{
Richard B. Wanty ${ }^{1}$, Michele L. Tuttle ${ }^{1}$, Matthew K. Landon ${ }^{2}$, \\ Geoffrey N. Delin ${ }^{2}$, and J.K. Böhlke ${ }^{3}$
}

1U.S. Geological Survey, M.S. 916, Denver Federal Center, Denver, CO 80225

2U.S. Geological Survey, 2280 Woodale Dr., Mounds View, MN 55112

3U.S. Geological Survey, M.S. 431 National Center, Reston, VA 22092

\begin{abstract}
A broad interagency research program is being conducted near Princeton, Minnesota, to investigate possible advantages of various modifications to existing farming techniques with the goal of decreasing contamination of ground-water and surface-water supplies by agricultural chemicals. Most of the program is focused on a 160-acre test farm, with the intention that the results from the test farm be applied to other farms in the area. To facilitate extending the results to a broader region, a study was conducted to investigate regional effects of agricultural activity on nitrogen in ground waters and surface waters of the Battle Brook watershed. Shallow ground water has received the greatest inputs of nitrate-nitrogen. Concentrations of nitrate-nitrogen (nitrate-N) exceeding 10 milligrams per liter $(\mathrm{mg} / \mathrm{L})$ as $\mathrm{N}$ are common near the water table. Nitrate-N concentrations decreased rapidly with depth (deeper than about 8 to 10 meters) in the saturated zone throughout the watershed, possibly because of mixing with uncontaminated waters or because of denitrification. Extensive wetlands in the area are fed by the discharge of shallow ground water, yet nitrate- $\mathrm{N}$ was not detected in any wetland waters. Biological activity in the wetland and its sediments decreases nitrate- $\mathrm{N}$ concentrations. Monthly to bimonthly sampling of a piezometer near the water table at the Princeton test farm during July, 1991 to August, 1992, shows that nitrate-N concentrations varied between 13 and $25 \mathrm{mg} / \mathrm{L}$ in response to seasonal recharge events. The magnitude of the variation decreased with depth; about 2 meters below the water table, nitrate- $\mathrm{N}$ concentrations ranged from 12 to $17 \mathrm{mg} / \mathrm{L}$.
\end{abstract}




\section{ABSTRACT}

Research at the Northern Cornbelt Sand Plains Management Systems Evaluation Area [MSEA] at Princeton, Minnesota, was conducted to characterize the variability of whole-plant $\mathrm{N}$ uptake and soil-water content under a continuous corn-cropping system. The soil was a Zimmerman fine sand (mixed, frigid, Alfic Udipsamment). Nitrogen [N] fertilizer was applied uniformly in 1991 and 1992. In 1991 and 1992, whole-corn-plant samples were collected in 15-m [meter] intervals along a 244-m-long transect to determine $\mathrm{N}$ uptake. In 1992, plastic neutron-moisture-meter access tubes were placed to a depth of 2 $\mathrm{m}$ every $20 \mathrm{~m}$ along the same transect. N uptake ranged from 115 to $157 \mathrm{~kg} \mathrm{~N}$ $\mathrm{ha}^{-1}$ [kilograms $\mathrm{N}$ per hectare] in 1991 and 92 to $132 \mathrm{~kg} \mathrm{~N}^{-1}$ in 1992. Mean uptake of $\mathrm{N}$ was $24 \mathrm{~kg} \mathrm{ha}{ }^{-1}$ greater in 1991 than it was in 1992. Soil-water content ranged from 10 to $15 \mathrm{~cm}$ [centimeters] for the upper 1.7-m depth interval on July 23, 1992. The area where $N$ uptake in 1992 was least is a sideslope area where the surface soil was driest. Leaching may have occurred during recharge events during the growing season at this and positions in the terrain.

\footnotetext{
${ }^{1}$ Associate Professor, Soil Science Department, University of Minnesota, St. Paul, MN 55108 .

${ }^{2}$ Research Fellow, Soil Science Department, University of Minnesota, St. Paul, MN 55108 .

${ }^{3}$ Professor and Director of Center for Agricultural Impacts on Ground Water Quality, Soil Science Department, University of Minnesota, St. Paul, MN 55108 .

${ }^{4}$ Research Leader and Soil Scientist with United States Department of Agriculture - Agricultural Research Service, St. Paul, MN 55108.
} 


\title{
GEOPHYSICAL INVESTIGATIONS OF HETEROGENEITY AND SCALE AT THE PRINCETON, MINNESOTA,MANAGEMENT SYSTEMS EVALUATION AREA
}

\author{
by Jeffrey E. Lucius ${ }^{1}$ and Gary R. Olhoeft ${ }^{1}$
}

The U.S. Geological Survey collected over 1 gigabyte of ground penetrating radar (GPR) data in 1991 at the Princeton, Minnesota Management Systems Evaluation Area (MSEA) to generate detailed images of the subsurface and to determine the threedimensional spatial variability of hydrogeologic properties. The Princeton MSEA is located on the Anoka glacial outwash sand plain northwest of Minneapolis-St. Paul. The GPR system transmitted electromagnetic pulses which propagated through the ground. The pulses were partially reflected back to the GPR antennas when they encountered changes in electrical properties (which are controlled by water content, bulk density, lithology, and porosity). The GPR data were computer processed to produce geometrically correct images of the subsurface. Reflector continuity, amplitude, configuration, and spatial frequency were analyzed in the GPR images to determine lithologic structure, depositional processes, moisture content, stratification patterns, and grain-size distributions. Changes in water-table capillary fringe thickness, areas of possible focused recharge, areas consisting of eolian or other fine-grained deposition, and undulations of the till surface were identified. The GPR images were also correlated with lithology logs from sampling wells. For agricultural sites with very little or no clay near the surface, ground penetrating radar offers a fast, cost-effective, high-resolution method for extending information acquired at test wells and for presenting a comprehensive view of subsurface structure.

${ }^{1}$ U.S. Geological Survey, Denver, CO 


\title{
CHEMICAL LOADS OF NITRATE, ATRAZINE, AND METOLACHLOR IN WALNUT CREEK WATERSHED NEAR AMES, IOWA, 1991-92
}

\author{
by P.J. Soenksen ${ }^{1}$, J.L. Hatfield ${ }^{2}$, and D.J. Schmitz ${ }^{2}$
}

Streamflow, stormflow, and tileflow were measured and sampled at numerous sites in the Walnut Creek watershed near Ames, Iowa, to determine the chemical discharges, loads, and yields of nitrate as nitrogen (nitrate-N) and the herbicides atrazine and metolachlor. From April 1991 to September 1992, nitrate-N yield was $58.4 \mathrm{~kg} / \mathrm{ha}$ (kilograms per hectare), and atrazine and metolachlor yields were $4.5 \mathrm{~g} / \mathrm{ha}$ (grams per hectare) and $7.3 \mathrm{~g} / \mathrm{ha}$, respectively, in streamflow from a 2,540-ha (hectare) subwatershed. Large chemical discharges and increases in cumulative loads were closely related to stormflow. Chemical loads were larger during the 1991 growing season, when soils were wet and stormflow occurred shortly after application of chemicals, compared to loads during the 1992 growing season when stormflow did not occur until several months after application of chemicals. Nitrate-N was transported during periods of base flow throughout the year; there were many periods when the herbicides were not detected.

For July-August 1992, a comparison of loads and yields in streamflow from the subwatershed was made to those in stormflow and tileflow from a 360-ha small basin within the subwatershed. The comparison indicates that most of the chemical load in streamflow was transported by tileflow, and little was transported by stormflow, even during stormflow. There were four periods of stormflow during July-August 1992, but there were none in the preceding 2 months. Nitrate-N yields were $8.0 \mathrm{~kg} / \mathrm{ha}$ in streamflow, $0.06 \mathrm{~kg} / \mathrm{ha}$ in stormflow, and $7.9 \mathrm{~kg} / \mathrm{ha}$ in tileflow. Atrazine yields were 0.42 $\mathrm{g} / \mathrm{ha}$ in streamflow, $0.010 \mathrm{~g} / \mathrm{ha}$ in stormflow, and $0.50 \mathrm{~g} / \mathrm{ha}$ in tileflow. Metolachlor yields were $0.42 \mathrm{~g} / \mathrm{ha}$ in streamflow, $0.007 \mathrm{~g} / \mathrm{ha}$ in stormflow, and $0.35 \mathrm{~g} / \mathrm{ha}$ in tileflow. Comparison of daily yields, one during stormflow and one during base flow, with those from a field tile also indicate tileflow as the primary transporter of agricultural chemicals for this period.

${ }^{1}$ U.S. Geological Survey, Iowa City, IA

${ }^{2}$ Agricultural Research Service, Ames, IA 
Atrazine Transport Through Preferential Pathways

At the Missouri Management System Evaluation Area

James A. Tindall ${ }^{1}$ and William $\mathrm{K}$ Vencill ${ }^{2}$

\begin{abstract}
Results of experiments at the Missouri Management System Evaluation Area indicate that atrazine moved rapidly through the soil, probably due to the presence of a large number of cracks and macropores. Data also show that concentrations of atrazine exceeding $0.50 \mu \mathrm{g}$ $\mathrm{mL}^{-1}$ were observed with depth $(45-135 \mathrm{~cm})$ after several months following heavy recharge events. It appears that macropores were a major factor in atrazine transport at the site. Agriculture practices designed to reduce surface cracking (which will reduce access to macropores) and chemical input could play a major role in lessening contamination of ground water in the Midwest.
\end{abstract}

${ }^{1}$ U.S. Geological Survey, NRP, Denver, Colorado.

${ }^{2}$ Department of Agronomy, University of Georgia, Athens 


\title{
MEASUREMENTS OF HYDRAULIC CONDUCTIVITY AND CAPILLARY PRESSURE
}

\section{UNDER UNSATURATED CONDITIONS IN A LABORATORY TRIAXIAL SYSTEM}

\author{
by Harold W. Olsen 1
}

\begin{abstract}
A new laboratory technique is being developed to provide media-specific measurements of hydraulic conductivity and capillary pressure under unsaturated conditions for modeling ground-water flow and contaminant transport in geologic systems. The technique is designed to test undisturbed specimens in a triaxial chamber under simulated in situ stress conditions and to provide direct and concurrent measurements of vertical hydraulic conductivity, capillary pressure, and the variation of these properties with degree of saturation. Constant-flow hydraulicconductivity measurements are conducted by infusing and withdrawing identical flow rates at opposite ends of a specimen with a flow pump and measuring the resultant induced head difference with a differential pressure transducer. Additional transducers and flow pumps are used to (1) measure the capillary pressure and effective stress, (2) control and change the water content of the specimen during and between hydraulic conductivity measurements, and (3) control the specimen volume. This new technique avoids fundamental limitations of the methods commonly used in current practice, including (1) the need for duplicate specimens and separate equipment for laboratory measurements of hydraulic conductivity under saturated conditions and soil water retention, (2) the lack of stress or volume control for simulating in situ conditions in the pressure plate or tempe cell equipment generally used to measure soil-water-retention curves, and (3) the need for pore-size-distribution models to estimate the relationship between hydraulic conductivity and degree of saturation from soil-water retention- data.
\end{abstract}

1U.S. Geological Survey, Golden, CO 80401 


\title{
UNSATURATED ZONE PROPERTIES AT A HAZARDOUS-WASTE-DISPOSAL SITE AT THE IDAHO NATIONAL ENGINEERING LABORATORY
}

\author{
by Stephanie Shakofsky ${ }^{1}$ and John R. Nimmo ${ }^{1}$
}

Field and laboratory investigations at a hazardous-waste site at the Idaho National Engineering Laboratory (INEL) have yielded measurements of the hydraulic properties that govern water and contaminant transport in the unsaturated zone. Saturated and unsaturated vertical hydraulic conductivity, soil-moisture retention, porosity, and particle-size distribution were measured in core samples collected from depths of 18 to $245 \mathrm{~cm}$. In addition, the degree of soil aggregation and relative carbonate content with depth were analyzed in the field. In order to assess the effect of the disposal trenches and pits on hydrologic transport-governing properties, studies were made of (1) a simulated waste trench that was constructed as a model of the waste-containing trenches, and (2) a nearby undisturbed soil profile. Results show that the undisturbed soil profile has distinct layers whose properties differ significantly, whereas the soil profile in the simulated waste trench is, to a large degree, homogeneous. In general, the vertical movement of water is expected to be retarded in a distinctly layered medium, suggesting that the construction of trenches and pits has destroyed some natural impediments to downward flow.

${ }^{1}$ U.S. Geological Survey, 345 Middlefield Rd., Mailstop 421, Menlo Park, Calif., 94025 
Session 9--Bemidji 


\title{
EVOLUTION OF THE CONTAMINANT PLUME IN AN AQUIFER CONTAMINATED WITH CRUDE OIL, BEMIDJ, MINNESOTA
}

\author{
by Mary Jo Baedecker ${ }^{1}$, Isabelle M. Cozzarelli ${ }^{1}$, Philip C. Bennett ${ }^{2}$, \\ Robert P. Eganhouse ${ }^{1}$, and Marc F. Hult ${ }^{1}$
}

\begin{abstract}
A long-term investigation of the geochemistry of a contaminant plume in an aquifer where crude oil floats on the water table indicates that the size of the plume has changed little over a 9year period. Even though the geochemical reactions have changed with time and part of the plume has become anoxic, the biodegradation of dissolved hydrocarbons under oxic and anoxic conditions has prevented the hydrocarbons, in concentrations above Federal maximum contaminant levels, from moving more than 100 meters downgradient from the oil body. Another factor that helps contain the plume is the presence of silt layers of low hydraulic conductivity near the oil and the top of the saturated zone. Large concentrations of petroleum-type hydrocarbons can be attenuated or removed from aquifers by natural hydrologic and biogeochemical processes.
\end{abstract}

\footnotetext{
1 U.S. Geological Survey, 431 National Center, Reston, Virginia 22092

${ }^{2}$ University of Texas at Austin, Department of Geological Sciences, Austin, Texas 78712
} 


\title{
Use of simulation to study field-scale solute transport and biodegradation at the Bemidji, Minnesota, crude-oil spill site
}

\author{
H.I. Essaid', M.J. Baedecker², and I.M. Cozzarelli ${ }^{2}$
}

\begin{abstract}
A two-dimensional, multispecies solute-transport model that includes aerobic and anaerobic degradation processes was developed and applied to the Bemidji, Minnesota, crude-oil spill site. The model was used as a tool to study the field-scale solute-transport and degradation processes. The simulations included the transport of degradable and refractory dissolved organic carbon, dissolved oxygen, and methane, as well as aerobic and anaerobic (methanogenic)

biodegradation. Despite the considerable uncertainty in the model parameter estimates, results of simulations reproduced the general features of the observed ground-water plume. In addition to the kinetics of the biodegradation processes, important factors that affect the distribution of the solutes in the field are the recharge influx and the degree of dispersion and mixing in the ground water system. Recharge influx causes flow lines in the aquifer to be deflected downward from the water table causing downward movement of the plume. Biodegradation results in a narrow plume with sharp gradients at the margins. Spatial variability of hydraulic conductivity increases the amount of carbon degraded by aerobic and anaerobic processes.
\end{abstract}

${ }^{1}$ U.S. Geological Survey, Menlo Park, CA

${ }^{2}$ U.S. Geological Survey, Reston, VA 


\title{
SOURCE MASS BALANCE CALCULATED FROM CHANGES IN COMPOSITION OF SPILLED CRUDE OIL IN THE SUBSURFACE NEAR BEMIDJI, MINNESOTA
}

\author{
by Matthew K. Landon ${ }^{1}$ and Marc F. Hult ${ }^{1}$
}

\begin{abstract}
The transport and fate of crude oil that spilled from a break in a buried pipeline near Bemidji, Minnesota on August 20,1979 has been monitored by the U.S. Geological Survey since 1983. The oil percolated to the water table in a glacial outwash aquifer. The oil has moved about $30 \mathrm{~m}$ (meters) as a separate fluid phase in the aquifer and is preferentially losing soluble and volatile compounds through dissolution into ground water and vaporization into the unsaturated zone. As part of the research effort at the site, the evolution of the composition and physical properties of the oil in the subsurface was studied. The primary objectives were to (1) quantify changes in the composition and physical properties of the oil at the site, (2) compare field results with oil alteration under controlled laboratory conditions that simulated the field environment, and (3) estimate mass balances for the total oil and for individual compounds mobilized during natural alteration of the oil source. Analysis of oil collected from monitoring wells screened in the oil bodies during 1988 and 1989 indicated that areal differences in the physical properties of the oil have developed because of spatially and temporally variable rates of alteration of the originally uniform oil. The composition of the oil fraction lighter (with a lower carbon number) than dodecane (a normal alkane with 12 carbon atoms) of field and laboratory aged samples of oil was determined using gas chromatography/mass spectroscopy (GC/MS). The oil has selectively lost aromatic compounds and aliphatic compounds (normal, branched, and cyclic alkanes) more volatile than nonane (normal alkane with nine carbons). About 50 detectable compounds have been depleted in the fraction of the oil that was analyzed. Maximum depletions of the total mass of C3 (compounds with three carbons), C4, C5, C6, C7, C8, C9, and C10 compounds were 100, 100, 95, $81,66,48,49$, and 25 percent, respectively. Depletion of the total mass of aromatic compounds ranged from 30 to 84 percent and exceeded depletion of the total mass of aliphatic compounds, which ranged from 0 to 73 percent. The greater depletion of aromatic compounds may indicate that dissolution of aromatic compounds into water initially occurs at greater rates than losses of aliphatic compounds by volatilization. Because of the much greater abundance of aliphatic compounds in the oil, however, more than 70 percent of the mass loss from the oil likely occurs as a result of volatilization. Losses of $\mathrm{C} 6$ and C7 aliphatic compounds account for a majority of the total loss of mass from the oil. Total mass loss from the oil calculated from changes in oil composition agrees within 0 to 3.8 percent (median of 1.6 percent) to mass loss calculated from changes in specific gravity, refractive index, and kinematic viscosity, indicating that any of these properties can be used for mass-balance calculations. Minimum estimates of total mass loss from the oil based on changes in composition and physical properties range from 0 to 11 percent (average is 3.8 percent) since the spill occurred in 1979. The results of mass loss calculations provide an independent estimate of the spatially variable source term for transport models of volatile and soluble hydrocarbons emanating from the oil source in the subsurface.
\end{abstract}

${ }^{1}$ U.S. Geological Survey, WRD, Mounds View, Minnesota 


\title{
INVESTIGATIONS OF MINERAL DIAGENESIS BY MICROBES
}

\author{
by Philip C. Bennett and Franz K Hiebert ${ }^{1}$
}

\begin{abstract}
Mineral weathering in an oil-contaminated aquifer near Bemidji, Minnesota, was investigated using in situ methods. Small microcosms containing clean, freshly fractured, mineral fragments were suspended for $\sim 1$ year in wells penetrating the aquifer, and the mineral surfaces were then examined for evidence of microbial colonization and mineral diagenesis. After reaction, feldspar and quartz surfaces were lightly colonized with a variety of microfauna. Feldspars were deeply etched near microbial colonies, whereas an unidentified clay precipitate was found on uncolonized surfaces of the same fragment. Quartz was lightly etched, with a generally roughened surface and scattered triangular etch pits, whereas most of the calcite showed evidence of carbonate precipitation. These results, combined with 10 years of geochemical data collected at the site, illustrate a complex geochemical system where microbial processes drive multiple reactions that are reflected in the mineral-surface diagenetic textures.
\end{abstract}

${ }^{1}$ Dept. of Geological Sciences, The University of Texas at Austin, Austin, TX 
Session 10--San Francisco Bay 


\title{
CHALLENGES IN DETECTING EFFECTIVE CONTAMINANTS ON AN ESTUARINE ECOSYSTEM INFLUENCED BY MANY DISTURBANCES: SAN FRANCISCO BAY \\ By Samuel N. Luoma, Federic H. Nichols, and Cynthia Brown, U.S. Geological Survey, Mail Stop 465, Menlo Park, California 94025
}

\begin{abstract}
Recent studies demonstrate that Suisun Bay/Delta, at the head of San Francisco Bay, is an area where complex factors converge to affect the success of aquatic species. The positioning of the salinity gradient, as affected by river flow, is an ecological factor of over-riding importance. Water diversion and drought have reduced river flows to the bay. Coincidentally, populations of important resource species have declined. Organic carbon inputs have a broad ecological effect in estuaries. In suisun Bay, long term marsh destruction has permanently removed an important source of carbon, drought has reduced river-borne inputs of carbon, and changes in the food web have reduced available carbon in the water column. Invasion by an exotic clam ( $P$. amurensis) has affected the abundance of benthic species that occupied the estuary prior to the invasion and has changed the carbon cycle in ways that could affect pelagic fish populations. Persistent contamination in Suisun Bay/Delta accentuates the adverse effects of the above first-order problems. Selenium contamination in benthos is sufficient to affect upper-trophic-level organisms such as birds and fish. Pulse inputs of pesticides occur during high flows. Locations in Suisun Bay were identified that are chronically contaminated with trace organic compounds, cadmium, chromium, and vanadium. At these locations resident bivalves are in poorer condition and have modified reproductive cycles, compared to elsewhere in the estuary. Long-term studies are allowing identification of the relative importance of different factors that disturb biological processes in the estuary. Few multi-disciplinary, long-term field studies are conducted in environments modified by human disturbance. Results from suisun Bay show how continuity in the study of cause-and-effect may be the only way to separate the influence of the myriad of processes that contribute to ecological characteristics in estuaries.
\end{abstract}




\title{
DIAZINON CONCENTRATIONS AND TRANSPORT IN THE SACRAMENTO RIVER AND SAN FRANCISCO BAY, CALIFORNIA, FEBRUARY 1993
}

\author{
by Kathryn M. Kuivila ${ }^{1}$ and Dwight D. Copeland ${ }^{1}$
}

\begin{abstract}
Previous studies of pesticide concentrations in the Sacramento River suggest that narrow pulses of diazinon, a major dormant spray pesticide, are transported down the river following rainfall. A study in February 1993 followed these anticipated pesticide pulses down the Sacramento River and into San Francisco Bay. Water samples for pesticide analysis were collected daily at four sites in the river and bay. Three distinct pulses of diazinon were detected in the Sacramento River at Sacramento 1 to 3 days after rainfall. The load of diazinon in the Sacramento River in February was calculated to be 340 kilograms (active ingredient) or approximately 0.5 to 1.7 percent of the total diazinon applied to orchards in the Sacramento Valley in January and February. The diazinon pulse detected at Sacramento on February 12 was detected the next day at Rio Vista, 2 days later at Chipps Island (the boundary between the delta and San Francisco Bay), and 3 to 5 days later at Martinez (the western edge of Suisun Bay). Study results suggest that the transport of pesticides from the Sacramento River into San Francisco Bay is episodic and highly dependent on rainfall and flow conditions.
\end{abstract}

${ }^{1}$ U.S. Geological Survey, Sacramento, Calif. 


\title{
HYDRODYNAMICS OF CALIFORNIA'S SACRAMENTO-SAN JOAQUIN DELTA, AND THE COLLECTION OF FLOW DATA FOR THE TRACKING OF PESTICIDES
}

\author{
by Richard N. Oltmann ${ }^{1}$
}

The Sacramento and San Joaquin Rivers drain the Central Valley of California where 10 percent of the pesticides used in the United States are applied. The two rivers converge at the head of San Francisco Bay forming a complex delta consisting of many interconnected sloughs and channels. The tracking of pesticides within and through the delta is difficult because flows are being manipulated constantly and measured-flow data are lacking. Ultrasonic velocity meters and an acoustic Doppler flow-measuring system are being used to collect the flow data necessary to improve understanding of the hydrodynamics of the delta and to track pesticides entering the delta.

${ }^{1}$ U.S. Geological Survey, Sacramento, CA 


\title{
CONCENTRATIONS OF DISSOLVED RICE PESTICIDES IN THE COLUSA BASIN DRAIN AND SACRAMENTO RIVER, CALIFORNIA, 1990-92
}

\author{
by Kathryn L. Crepeau ${ }^{1}$, Kathryn M. Kuivila ${ }^{1}$, \\ and Joseph L. Domagalski ${ }^{1}$
}

The measured concentrations of rice pesticides in the Colusa Basin Drain and the Sacramento River, California, decreased during 1990-92. Molinate, carbofuran, and thiobencarb are applied to the Sacramento Valley ricefields in April, May, and June. These pesticides are of concern because of the potential effect of discharge water from the ricefields on striped bass larvae.

Concentrations of dissolved pesticides from ricefields were measured at the Colusa Basin Drain (a major source of ricefield drainage) and the Sacramento River at Sacramento, Rio Vista, and Chipps Island during May, June, and July each year. The highest pesticide concentrations were measured at the Colusa Basin Drain with progressively decreasing concentrations downstream, principally because of dilution. During 1990-92, the maximum molinate concentration in the Colusa Basin Drain decreased by a factor of three each year. The maximum carbofuran concentration decreased by a factor of four during 1990-91. In contrast, the maximum carbofuran and thiobencarb concentrations in 1992 remained at the 1991 concentrations. The holding time before ricefield water could be discharged into the Sacramento River increased yearly during 1990-92. This allowed further degradation of the pesticides and resulted in the decreased concentrations of pesticides measured in the Colusa Basin Drain water and downstream sites.

${ }^{1}$ U.S. Geological Survey, Sacramento, Calif. 


\title{
A SURVEY OF MOLECULAR MARKER COMPOUNDS IN SEDIMENTS OF SAN FRANCISCO BAY, CALIFORNIA
}

Frances D. Hostettler, John B. Rapp, Wilfred E. Pereira, and Keith A. Kvenvolden

U.S. Geological Survey, Menlo Park, CA.

\begin{abstract}
An areal survey of surficial sediments in San Francisco Bay has been conducted to evaluate the presence of extractable organic compounds. Molecular marker compounds studied include hydrocarbons (PAH's), chlorinated pesticides, and other organic compounds that provide information on sources of organic input into the Bay. Fairly uniform source profiles are seen throughout the Bay. Biomarker profiles contain mature constituents indicating anthropogenic influences and extensive sediment reworking. The dominant input signatures in San Francisco Bay sediment are those of anthropogenic PAH's from combustion and other sources, and long chain $n$-alkanes and $n$-aldehydes from terrigenous vascular plants. A comparison of the sums of the combustion PAH's and the terrigenous $n$-alkanes shows that an anthropogenic influence is dominant in the most urban parts of the Bay close to shore, and in mid-Bay channel areas, and a terrigenous signature is dominant nearshore in San Pablo Bay and at the southernmost station in South Bay.
\end{abstract}


Session 11--Upper Arkansas River 


\title{
PAST AND PRESENT RESEARCH ON METAL TRANSPORT IN ST. KEVIN GULCH, COLORADO
}

\author{
by Briant A. Kimball ${ }^{1}$
}

To prepare for mitigation of the effects of acidic mine drainage on upland watersheds, process-oriented research at St. Kevin Gulch has focused on chemical reactions that affect metal transport and partitioning among phases. We operationally defined dissolved and colloidal transport phases and the speciation of iron because the cycle of iron can affect the cycling of other metals. With these phases defined, our approach was to study chemical reactions in the context of hydrologic transport. By establishing the hydrologic setting with tracer-dilution injections, we studied temporal and spatial variability in metal concentrations resulting from combined hydrologic and chemical processes. Temporal and spatial aspects of variation were combined in an instream $\mathrm{pH}$ modification experiment to evaluate the kinetics of reactions involving metals. These data are the focus of a simulation model that combines transport and reactive chemistry of metals. Ongoing studies of the ecological system are in anticipation of higher $\mathrm{pH}$ and lower metal concentrations that should follow remediation by a passive treatment system. 


\title{
IRON AND ZINC BUDGETS IN SURFACE WATER FOR A NATURAL WETLAND AFFECTED BY ACIDIC MINE DRAINAGE, ST. KEVIN GULCH, LAKE COUNTY, COLORADO
}

\author{
By Katherine Walton-Day ${ }^{1}$
}

\begin{abstract}
Iron and zinc mass input and output in surface water were estimated for a wetland receiving acidic mine drainage near Leadville, Colorado, to evaluate (1) whether the wetland is removing the metals from surface water, and (2) the processes causing the observed metal fate. The results indicate that about 560 and 830 kilograms of iron were removed from surface water from late spring through fall 1988 and from late spring through mid-summer 1989, respectively. Iron removal occurred primarily through settling of iron oxyhydroxide particles greater than 0.1 micrometer. The results also indicate that zinc was not removed from surface water by the wetland. All of the zinc is in the filtered fraction. Either contact time between the water and the wetland substrate is insufficient for the reactions that could remove dissolved zinc, such as sulfate reduction, to occur, or zinc removal reactions do not occur in this wetland.

${ }^{1}$ U.S. Geological Survey, Denver, Colo.
\end{abstract}


TRACER INJECTIONS IN SMALL STREAMS--WHY AND HOW WE DO THEM

by Gary w. Zellweger

U.S. Geological Survey, Menlo Park, CA 94025

Using simple techniques and imagination, researchers can use conservative tracer injections to collect hydrological data on small streams. Stream hydrologic properties such as discharge, which can not be measured by other means, are measurable with a precision two percent or better, by use of conservative tracers. This paper briefly describes some of the hydrologic information that can be gained from continuous injection experiments that may last from a few minutes to several days, and provides details of tracer selection criteria, injection equipment, and sampling and tracer analysis. Typical formulas used to calculate some of the hydrologic properties from tracer data and guides to conducting tracer experiments are included. 


\title{
PROCESSES CONTROLLING DISSOLVED COPPER CONCENTRATIONS DURING AN INSTREAM PH-MODIFICATION EXPERIMENT
}

\author{
by Kathleen S. Smith ${ }^{1}$
}

\begin{abstract}
Changes in dissolved copper $(\mathrm{Cu})$ concentrations as a function of $\mathrm{pH}$ were observed during an instream $\mathrm{pH}$-modification experiment conducted in St. Kevin Gulch, Colorado, a stream affected by acidic mine drainage. Understanding the processes that control dissolved $\mathrm{Cu}$ concentrations is important because dissolved $\mathrm{Cu}$ can pose health risks and contaminate receiving waters. Comparison of dissolved $\mathrm{Cu}$ concentrations during the instream experiment with changes in dissolved $\mathrm{Cu}$ concentrations in inbottle simulation experiments performed with streamwater in the absence of streambed sediment shows good agreement. These data indicate that processes controlling $\mathrm{Cu}$ attenuation with increasing $\mathrm{pH}$ occur primarily in the water column. Sorption reactions and (or) coprecipitation reactions with iron and (or) aluminum precipitates forming in the water column in response to increasing $\mathrm{pH}$ may be the processes controlling $\mathrm{Cu}$ partitioning in these systems. Predictive computer modeling of $\mathrm{Cu}$ sorption onto hydrous ferric oxide slightly underestimates $\mathrm{Cu}$ attenuation observed in the instream system.
\end{abstract}

1 U.S. Geological Survey, Geologic Division, Box 25046, Denver Federal Center, M.S. 973, Denver, CO 80225-0046 


\title{
AN EQUILIBRIUM-BASED SIMULATION MODEL FOR REACTIVE SOLUTE TRANSPORT IN SMALL STREAMS
}

\author{
by Robert L. Runkel ${ }^{1}$, Kenneth E. Bencala ${ }^{2}$ and Robert E. Broshears ${ }^{3}$
}

A reactive solute transport model that considers the physical and aphysical processes affecting solutes in small streams is presented. The model is developed by coupling an existing solute transport code with a model of chemical equilibria. The resultant model considers a variety of physical and chemical processes including advection, dispersion, transient storage, precipitation/ dissolution, sorption/desorption and the deposition of particulate metal oxides.

${ }^{1}$ U.S. Geological Survey, Denver, CO; University of Colorado, Center for Advanced Decision Support in Water and Environmental Systems (CADSWES)

${ }^{2}$ U.S. Geological Survey, Menlo Park, CA

${ }^{3}$ U.S. Geological Survey, Denver, CO 


\title{
SIMULATION OF REACTIVE TRANSPORT DURING A pH MODIFICATION EXPERIMENT IN A MOUNTAIN STREAM AFFECTED BY ACID MINE DRAINAGE
}

\author{
by Robert E. Broshears ${ }^{1}$, Briant A. Kimball ${ }^{2}$ and Robert L. Runkel ${ }^{3}$
}

A field experiment in a mountain stream in Colorado has helped to quantify hydrologic and chemical processes that control the transport of metals in water affected by acid mine drainage. Injection of sodium carbonate raised instream $\mathrm{pH}$ from 3.5 to a maximum of 5.8. Responses of aluminum and iron concentrations during the injection indicated the formation of aluminum and iron hydroxysulfate solid phases. Simulation of these responses using a reactive transport model reproduced the general aspects of observed patterns of concentration changes. Discrepancies between simulated and observed concentrations indicated the importance of chemical interactions between the water column and the streambed and kinetic restraints on the attainment of equilibrium.

\footnotetext{
${ }^{1}$ U.S. Geological Survey, Denver, CO

${ }^{2}$ U.S. Geological Survey, Salt Lake City, UT

${ }^{3}$ U.S. Geological Survey, Denver, CO; University of Colorado, Center for Advanced Decision Support in Water and Environmental Systems (CADSWES)
} 


\title{
Session 12--Poster Presentations
}

\author{
Bemidji
}

Fate of Hydrocarbons in the Environment

\author{
San Francisco Bay
}

\section{Fate of Organic Contaminants in Surface Water}

Upper Arkansas River 


\title{
Multiphase-flow modeling of the Bemidji, Minnesota crude-oil-spill site with geostatistical simulation of hydraulic properties
}

\author{
By L.A. Dillard ${ }^{1,2}$, H.I. Essaid ${ }^{2}$, and W.N. Herkelrath ${ }^{2}$
}

This paper describes a study aimed at improving the understanding of multiphase flow in a heterogeneous aquifer by using data collected at the north pool sub-region of a crude-oil-spill site near Bemidji, Minnesota. Data collected include grain-size distributions, oil and water saturations ${ }^{3}$, and porosities of samples collected at the north pool site. These data are used to estimate permeability (k), retention curves, and the geometric mean and standard deviation of the sampled grain-size distributions. The $\mathrm{k}$ estimates are statistically distributed in a bimodal lognormal fashion, whereby the two $\mathrm{k}$ population distributions correspond to the two predominant aquifer lithologies at the north pool: a coarse glacial-outwash deposit and interbedded fine-silt lenses. A dual geostatistical approach involving sequential indicator and Gaussian simulation is used to characterize the bimodal aquifer heterogeneity present at the north pool by creating one realization of a three-dimensional grid of $\log (\mathrm{k})$ values conditioned on the original data.

Field oil-saturation data indicate that the spatial distribution of oil in the subsurface has been affected by the bimodal aquifer heterogeneity present at the north pool. The shape of the subsurface oil-saturation distribution is highly irregular; more specifically, the center of the oil lens is actually depressed below the water table in some locations, and oil saturations almost as high as 0.3 occur in the unsaturated zone. A cross-sectional numerical model is used to simulate the flow of oil and water at the north pool, assuming the air phase is at atmospheric pressure. A slice of the three-dimensional grid of $\log (\mathrm{k})$ values produced through geostatistical simulation is used as input in the multiphase model to investigate the effect of aquifer heterogeneity on multiphase flow. Flow simulations using the bimodal representation of heterogeneity produce an oilsaturation distribution that is similar to that found in the field. Other factors affecting multiphase flow, such as hysteresis and three-phase oil relative permeability, also are investigated. The effects of hysteresis are not as significant when heterogeneity is adequately characterized.

\footnotetext{
${ }^{1}$ Department of Applied Earth Sciences, Stanford University, Stanford, CA, 94305-2225.

2 U.S. Geological Survey, 435 Middlefield Rd., Menlo Park, CA, 94025.

${ }^{3}$ Fluid saturation refers to the volume of the fluid phase relative to the volume of pores in the sample.
} 
Studies of the Molecular Size of Dissolved Organic Carbon Fractions Downgradient from the Oil Body at Bemidji, Minnesota

by George Aiken ${ }^{1}$

Preliminary results of equilibrium dialysis measurements on wholewater samples and isolates of the hydrophobic acid fraction of the dissolved organic carbon (DOC) in ground water at the Bemidji, Minn., toxic-waste study site are presented. Membranes with 2,000 (2K)-dalton and 12,000 (12K)-dalton cutoffs were used. Approximately 10 percent of the DOC in the whole-water sample from well 530 B was excluded from the $2 \mathrm{~K}$-dalton-cutoff membrane. Similar results were obtained with aqueous solutions of the hydrophobic acid fraction isolated from water from well $530 \mathrm{~B}$. These results differed markedly from those obtained with aqueous solutions of the hydrophobic organic acid fraction from water from well 310 , a background-water-quality well, where approximately 30 percent of the DOC was excluded from the $2 \mathrm{~K}$-dalton membrane. Measurements made on whole-water samples from two other wells in the contaminated plume indicate that the amount of organic matter excluded from the $2 \mathrm{~K}$-dalton membrane increases with decreasing distance to the oil body, possibly because of organic-matter/iron or organicmatter/organic-matter interactions. The results suggest that colloid-sized organic constituents are generally absent from the ground water but that interactions of DOC with other dissolved constituents could result in an increase in molecular size of DOC fractions.

1 U. S. Geological Survey, Water Resources Division, 3215 Marine Street, Boulder, Colorado 80303 


\title{
SMALL-SCALE CHEMICAL HETEROGENEITIES IN A CRUDE-OIL-CONTAMINATED AQUIFER, BEMIDJI, MINNESOTA
}

\author{
By Isabelle M. Cozzarelli ${ }^{1}$, Mary Jo Baedecker ${ }^{1}$, George Aiken ${ }^{2}$, \\ and Curtis Phinney ${ }^{1}$
}

A study of the spatial heterogeneity of biogeochemical reactions was undertaken in an aquifer affected by a crude-oil spill near Bemidji, Minnesota. An anoxic plume extended 90 meters downgradient from the crude-oil body in 1992, and contained elevated concentrations of dissolved organic carbon, methane, ferrous iron, and manganese. Two 1.5meter-long continuous cores were collected from two locations within the anoxic plume to determine small-scale chemical heterogeneities in the ground water. Chemistry of porewater in a core collected from near the edge of the crude-oil body indicates that oxygenated water does not mix with the anoxic plume. The effects of mixing oxygenated ground water with the anoxic plume is reflected in the chemistry of porewater in a core collected 25 meters farther downgradient; mixing resulted in significant small-scale chemical heterogeneity in the concentrations of organic and inorganic chemical constituents.

\footnotetext{
${ }^{1}$ U.S. Geological Survey, 12201 Sunrise Valley Drive, MS 431, Reston, Virginia 22092

${ }^{2}$ U.S. Geological Survey, 3215 Marine St., Boulder, Colorado 80303
} 
USE OF CARBON AND HYDROGEN STABLE ISOTOPES TO INVESTIGATE THE PRODUCTION AND

FATE OF METHANE AT A TOXIC WASTE SITE, BEMIDJI, MINNESOTA

by Kinga Revesz ${ }^{1}$, Tyler Coplen ${ }^{1}$, Mary J. Baedecker ${ }^{1}$ and Marc Hult ${ }^{2}$

Stable carbon and hydrogen isotope ratios of dissolved methane and aqueous carbon dioxide in the saturated zone of a crude oil spill near Bemidji, Minn., support methane production by acetate fermentation with concomitant increase in bicarbonate concentration as opposed to carbon dioxide reduction (and bicarbonate consumption). Oxidation of dissolved methane along the lateral flow path seems to be minimal because no measurable change in isotopic composition of methane occurs with distance from the oil body. As methane from the ground water diffuses upward through a 5- to 7-meter-thick unsaturated zone, it is partially oxidized to carbon dioxide, increasing the $\delta^{13} \mathrm{C}$ of the remaining methane, decreasing the $\delta^{13} \mathrm{C}$ of the carbon dioxide, and increasing the pressure of carbon dioxide in the unsaturated zone.

No increase of concentrations of atmospheric methane was detected at ground level directly above the oil plume; concentrations were identical to those of a background atmospheric sample.

1U.S. Geological Survey, 431 National Center, Reston, VA 22092.

2U.S. Geological Survey, 2280 Woodale Drive, Mounds View, MN 55112 . 


\title{
SORPTION OF POLYCYCLIC AROMATIC HYDROCARBONS TO AQUIFER MATERIALS CONTAINING A LOW-ORGANIC CARBON CONTENT FROM BEMIDJI, MINNESOTA
}

\author{
by Joseph J. Piatt', Steven J. Eisenriech ${ }^{2}$, Debera A. Backhus ${ }^{3}$, \\ and Paul D. Capel ${ }^{4}$
}

Three polycyclic aromatic hydrocarbons, naphthalene, phenanthrene, and pyrene -- were sorbed to a single sample of aquifer material containing a low-organic carbon content at two different temperatures, $5^{\circ} \mathrm{C}$ and $25^{\circ} \mathrm{C}$, using batch and column experimental techniques. Controls on batch and column techniques were incorporated to ensure that the experimental vessels were organic-carbon free, biological and photolytic activity was absent, and solution supernates were colloid-free. The sorptive uptake curves indicated a two-step approach to equilibrium. The data were modelled using a two-site sorption kinetic model. Times to equilibrium were at least 40 hours. Small increases in equilibrium distribution coefficients were observed with decreased temperature which resulted in enthalpy of sorption values which were consistent with a partitioning mechanism. Small decreases in rate constants were occurred as temperature decreased. The values of the solids/water distribution coefficients for the batch experiments were consiseently 4 to 60 times larger than those obtained from the column experiments, probably because of differences in experimental boundary conditions or to creation of fine particles in the batch experiments that would increase the surface area available for sorption. Although the relative effects of organic-carbon phase sorption versus mineral phase sorption were not isolated directly, the magnitude of the observed distribution coefficients and rate constants are consistent with sorption controlled by the organic-carbon content of this aquifer material.

${ }^{1}$ Dept. of Soil and Water Science, Univ. of Arizona, Tucson, AZ

${ }^{2}$ Gray Freshwater Biological Institute, Univ. of Minnesota, Navarre, MN

${ }^{3}$ School of Public and Environmental Affairs, Indiana Univ., Bloomington, IN

${ }^{4}$ U.S. Geological Survey, Navarre, MN 


\title{
EFFECTS OF Pb AND TERMINAL-ELECTRON-ACCEPTING PROCESSES ON ORGANIC ACID CONCENTRATIONS IN CONTAMINATED AQUIFER SEDIMENTS
}

\author{
by Paul M. Bradley ${ }^{1}$, Francis H. Chapelle ${ }^{1}$, and Don A. Vroblesky ${ }^{1}$
}

The effects of terminal-electron-accepting processes (TEAPs) and dissolved $\mathbf{P b}$ concentrations on carbon mineralization and organic acid accumulation in petroleumcontaminated sediments were examined under aerobic, nitrate reducing, sulfate reducing, and methanogenic conditions. $\mathrm{Pb}$ concentrations in the 14 to $60 \mu \mathrm{g} / \mathrm{L}$ range observed in the field significantly inhibited $\mathrm{CO}_{2}$ production for all TEAPs as well as $\mathbf{C H}_{4}$ production under methanogenic conditions. However, accumulation of organic acids was more closely related to the dominant TEAP. Acetic, propionic, i-butyric, and nbutyric acids accumulated in methanogenic treatments, whereas only acetic acid was detected in sulfate reducing treatments. As expected, no organic acids were detected under nitrate reducing or aerobic conditions. This pattern parallels field observations in which high concentrations of organic acids (acetic, propionic, i-butyric, and n-butyric acids) were detected in methanogenic zones, but only low concentrations of acetic acid were detected in sulfate reducing zones.

${ }^{1}$ U.S. Geological Survey, Stephenson Center - Suite 129, 720 Gracern Rd, Columbia, SC 


\section{SHIFTING OF TERMINAL-ELECTRON-ACCEPTING PROCESSES IN A PETROLEUM-HYDROCARBON-CONTAMINATED AQUIFER}

By Don A. Vroblesky ${ }^{1}$ and Francis H. Chapelle ${ }^{1}$

Measurements of dissolved hydrogen and other biologically active solutes in ground water from a shallow petroleum hydrocarbon-contaminated aquifer indicate that the distribution of microbial terminal electron accepting processes (TEAP's), such as methanogenesis, sulfate reduction, and ferric-iron reduction, is highly dynamic in both time and space. Delivery of sulfate to previously methanogenic zones by infiltrating recharge or lateral transport can result in a TEAP shift from methanogenesis to sulfate reduction. Conversely, lack of recharge and consumption of available sulfate can result in a shift from sulfate reduction to methanogenesis. Temporal shifts between sulfate and ferric-iron reduction were also observed.

${ }^{1}$ U.S. Geological Survey, Columbia, SC 


\title{
MODELING STEADY-STATE METHANOGENIC DEGRADATION OF PHENOLS IN GROUND WATER AT PENSACOLA, FLORIDA
}

\author{
Barbara A. Bekins ${ }^{1}$, E. Michael Godsy ${ }^{1}$, and Donald F. Goerlitz ${ }^{1}$
}

\begin{abstract}
Field and microcosm observations of methanogenic phenolic-compound degradation indicate that Monod kinetics theory governs the substrate disappearance but overestimates the observed biomass. In this paper, we present modeling results from an ongoing multidisciplinary study of methanogenic biodegradation of phenolic compounds in a sand and gravel aquifer at Pensacola, Florida. The aquifer is contaminated with chemicals and wastes used in wood treatment. Field-disappearance rates of four phenols match those determined in batch microcosm studies performed by other workers in a related study. The degradation process appears to be at steady state because the transported contaminants still are disappearing within 150 meters downgradient of the source even after a sustained influx over several decades. The existence of a steady-state degradation profile of each substrate together with a low bacteria density in the aquifer indicate that the bacterial population is exhibiting no net growth. This is possibly because of the oligotrophic nature of the biomass population in which growth and utilization are approximately independent of the phenolic-compound concentration for most of the concentration range. Thus, a constant bacteria growth rate should exist over much of the contaminated area, which may, in turn, be balanced by an unusually high decay or maintenance rate caused by hostile conditions or predation.

${ }^{1}$ U.S. Geological Survey, 345 Middlefield Rd., Menlo Park, Calif. 94025
\end{abstract}




\title{
MODELING BREAKTHROUGH OF NITROGEN HETEROCYCLIC COMPOUNDS IN LABORATORY COLUMNS CONTAINING CREOSOTE-CONTAMINATED AQUIFER MATERIAL
}

\author{
by Ean Warren ${ }^{1}$ and E. Michael Godsy ${ }^{1}$
}

Laboratory-column breakthrough curves for the nitrogen-containing heterocyclic compounds found in the water soluble fraction of creosote were modeled and compared assuming local equilibrium and nonequilibrium conditions. The aquifer material consisted of a low organic-carbon-content $(0.024$ percent organic carbon), low ion-exchange-capacity $(2 \mathrm{meq} / 100 \mathrm{~g})$ clayey sand. Retardation factors and partition coefficients for quinoline, $2(1 \mathrm{H})$-quinolinone, carbazole, and acridine, derived from breakthrough curves, were contrasted with those obtained from batch experiments. Retardation factors for quinoline and $2(1 \mathrm{H})$-quinolinone were comparable to each other, although those for carbazole and acridine were quite different despite similar chemical structures and octanol-water partition coefficients. Transport of quinoline, $2(1 \mathrm{H})$-quinolinone, and acridine is governed by organic and ionic interactions; however, transport of carbazole is controlled by organic interactions alone. In addition, although the local equilibrium assumption can be used to describe quinoline and $2(1 \mathrm{H})$-quinolinone breakthrough curves, carbazole and acridine breakthrough curves require nonequilibrium kinetics.

${ }^{1}$ U.S. Geological Survey, Menlo Park, CA 


\title{
PRELIMINARY ASSESSMENT OF JET FUEL CONTAMINATION OF AN ATOLL AQUIFER
}

\author{
by Gordon W. Tribble1, Roger W. Lee ${ }^{2}$, Duane S. Wydoski ${ }^{3}$, \\ Jill D. Torikai ${ }^{1}$, and Charles D. Hunt ${ }^{1}$, Jr.
}

Jet fuel spilled in 1991 on the atoll island of Diego Garcia (Chagos Archipelago, Indian Ocean) has contaminated one of the fresh ground-water lenses on the island. Freshwater lenses on the island are unconfined and strongly influenced by tidal oscillations in sea level. The U.S.

Geological Survey is using a multidisciplinary approach to (1) evaluate contaminant migration and, (2) determine the geochemical processes that affect contaminant degradation. A network of waterlevel recorders is being used to determine the effect of a hydraulic control scheme on the watertable configuration and contaminant transport. The water table near the spill is 1 to 2 feet above mean sea level and undergoes diurnal oscillations of as much as 4 feet in response to ocean tides.

Geochemical characterization of the aquifer will help to resolve ambient and fuel-affected levels and types of microbial oxidation. This information is useful to determine the need for, and type of, remediation of residual contamination after efforts to remove the fuel by pumping are completed. Initial data from the first of three planned trips indicate that natural levels of microbial oxidation are sufficient to deplete $\mathrm{O}_{2}$ in all aquifer waters. Concentrations of $\mathrm{CO}_{2}, \mathrm{CH}_{4}$, and $\mathrm{H}_{2} \mathrm{~S}$ indicate that the natural levels of microbial oxidation are enhanced by the presence of hydrocarbon contaminants. An evaluation of the rates, mechanisms, and limits of microbial oxidation in the aquifer will require additional sampling and physical measurements to assess hydraulic processes such as aquifer properties and the response of ground-water flow to different recharge and withdrawal conditions.

1 U.S. Geological Survey, Honolulu, Hawaii

2 U.S. Geological Survey, Austin, Texas

3 U.S. Geological Survey, Arvada, Colorado 


\title{
DISTRIBUTION AND POSSIBLE BIOLOGICAL EFFECTS \\ OF DIAZINON IN THE SAN JOAQUIN RIVER AND \\ THE SACRAMENTO-SAN JOAQUIN DELTA, \\ CALIFORNIA, FEBRUARY 1993
}

\author{
by Kathryn M. Kuivila ${ }^{1}$, Robert C. Sheipline ${ }^{1}$, \\ and Christopher G. Foe ${ }^{2}$
}

The distribution and possible biological effects of a dormant spray pesticide, diazinon, were examined by measuring pesticide concentrations and estimating toxicity by means of bioassays at a series of sites in the Sacramento-San Joaquin Delta. A double peak of diazinon concentration was observed in early February 1993 at Vernalis on the San Joaquin River after heavy rains; similar pulses were detected at Stockton 2 days later. Two geographically separate sources of diazinon--orchards along the western side of the San Joaquin River near Patterson and orchards along the Merced River--could account for the observed pattern of diazinon concentrations in early February. Distributions of diazinon at central delta sites on Old and Middle Rivers were not pulselike; instead, the concentrations steadily increased during the sampling period. Seven-day bioassays indicated that San Joaquin River water at Vernalis was acutely toxic to Ceriodaphnia dubia (water flea) for 12 consecutive days (February 8-19) with the highest diazinon concentrations. Examination of 96-hours $\mathrm{LC}_{50}$ values (lethal concentration that kills 50 percent of test organisms in 96 hours) indicates that measured diazinon concentrations could not account for all the observed toxicity. Other pesticides present could contribute to the toxicity.

\footnotetext{
${ }^{1}$ U.S. Geological Survey, Sacramento, Calif.

${ }^{2}$ California Regional Water Quality Control Board, Sacramento, Calif.
} 


\title{
METHOD FOR ESTIMATING THE ACTIVITY OF CARBOFURAN-DEGRADING MICROORGANISMS IN ENVIRONMENTAL SAMPLES
}

\author{
by William J. Meyers ${ }^{1}$ and Kathryn M. Kuivila ${ }^{1}$
}

\begin{abstract}
A method was developed to determine the presence and activity of carbofuran degrading organisms in aqueous field samples. Carbofuran is a broad spectrum systemic insecticide used on rice in the Sacramento Valley of California. Following the release of rice irrigation water, concentrations of carbofuran can be detected in agricultural drains and in the Sacramento River. Microbial populations influence the degradation rate of carbofuran in soils, but little is known about the importance of these organisms in the degradation of carbofuran in aqueous systems. The method described uses laboratory-scale microcosms containing an environmental culture and carbon-14 $\left({ }^{14} \mathrm{C}\right)$ ring-labeled carbofuran to evaluate the ability of microorganisms to degrade carbofuran. Degradation is indicated by the evolution of ${ }^{14} \mathrm{C}$-carbofuran-7-phenol and carbon-14/carbon dioxide $\left({ }^{14} \mathrm{C}-\mathrm{CO}_{2}\right)$. Ethyl acetate was used to extract the ${ }^{14} \mathrm{C}$ ring-labeled compounds from aqueous solution. ${ }^{14} \mathrm{C}$-carbofuran was resolved from ${ }^{14} \mathrm{C}$-carbofuran-7-phenol by means of thin layer chromatography, and the ${ }^{14} \mathrm{C}$ quantified using a radioisotope plate reader. Sodium hydroxide base traps were used to capture the ${ }^{14}{ }^{14}-\mathrm{CO}_{2}$ evolved from the cultures and quantified using a scintillation counter. The method was tested using three different aqueous cultures. Overall recoveries of ${ }^{14} \mathrm{C}$ were 66.8 percent plus or minus 6.3 percent at 95 -percent confidence interval ( $\mathrm{n}=24)$.
\end{abstract}

${ }^{1}$ U.S. Geological Survey, Sacramento, Calif. 


\section{DISTRIBUTIONS OF ORGANOCHLORINE COMPOUNDS IN SEDIMENTS AND LIVERS OF STRIPED BASS (Morone saxatilis) IN SAN FRANCISCO BAY-DELTA ESTUARY}

by Wilfred E. Pereira ${ }^{1}$, Frances D. Hostettler ${ }^{1}$, John R. Cashman ${ }^{2}$ and Richard S. Nishioka ${ }^{3}$

A preliminary assessment was made in 1992 of chlorinated organic compounds in sediments and in livers of striped bass from the San Francisco Bay-Delta Estuary. Samples of sediment and striped bass livers contain DDT (ethane, 1,1,1-trichloro-2,2-bis ( $p$-chlorophenyl)-) and its degradation products, DDD(ethane, 1,1-dichloro-2,2-bis(p-chlorophenyl)-) and DDE (ethylene, 1,1-dichloro-2,2-bis (p-chlorophenyl)-); polychlorinated biphenyls (PCB's); alpha and gamma chlordane, and cis and trans nonachlor. In addition, livers of striped bass contained small concentrations of DCPA (dimethyl tetrachloroterephthalate), a pre-emergent herbicide. The major source of DDT in the bay probably is from runoff from the San Joaquin and Sacramento Rivers. A point source of DDT near Richmond also may be responsible for the high concentrations of DDT in the Central Bay. Ratios of pentachloro to hexachloro isomers of PCB's suggest that sources of PCB's to the South, Central, and North Bays differ. Concentrations of alpha chlordane in livers of striped bass were greater than those of gamma chlordane suggesting a greater environmental stability and persistence of alpha chlordane. Trans nonachlor, a minor component of technical chlordane, was present in greater concentrations than alpha and gamma chlordane and cis nonachlor. Trans nonachlor is more resistant to metabolism than alpha and gamma chlordane and cis nonachlor, and serves as an environmentally stable marker compound. Chlorinated organic compounds are bioaccumulated in livers of striped bass. These compounds may contribute to the decline of striped bass in San Francisco Bay-Delta Estuary.

1 U.S. Geological Survey, Menlo Park, CA.

2 IGEN Research Institute, Seattle, WA.

3 Department of Integrative Biology,

Cancer Research Laboratory, and Bodega Marine Laboratory

University of California,

Berkeley, California 94720, USA 


\title{
DISTRIBUTIONS AND BENTHIC FLUX OF DISSOLVED SULFIDES IN THE OXIC WATER COLUMN OF SAN FRANCISCO BAY, CALIFORNIA
}

\author{
by James S. Kuwabara ${ }^{1}$, Yvonne R. Hunter ${ }^{1}$ and Cecily C.Y. Chang ${ }^{1}$
}

Chemical speciation affects the bioavailability of metals and organic ligands to planktonic and benthic organisms, as well as the partitioning of these solutes between phases. Our previous work in South San Francisco Bay indicated that sulfide complexation with metals can be of particular importance because of the thermodynamic stability of these complexes. Although the water column of the Bay is consistently well-oxygenated and typically unstratified with respect to dissolved oxygen, the kinetics of sulfide oxidation could exert at least transient controls on metal speciation. Our initial data on dissolved sulfides in the main channel of both the northern and southern components of the Bay consistently indicate submicromolar concentrations (from $<1$ to 162 nanomolar) as one would expect in an oxidizing environment. However, chemical-speciation calculations over the range of observed sulfide concentrations indicate that these trace concentrations in the Bay water column can markedly affect chemical speciation of ecologically significant trace metals, such as cadmium, copper and zinc. In contrast to longitudinal concentration gradients for dissolved organic carbon, dissolved sulfide concentrations were typically elevated at depth suggesting a primary benthic source. Subsequent flux core and in-situ flux chamber experiments support this hypothesis.

${ }^{1}$ U.S. Geological Survey, Menlo Park, CA 


\section{ORGANIC CARBON ASSOCIATED WITH SUSPENDED SILT \\ AND COLLOID FROM THE MISSISSIPPI RIVER AND \\ SOME OF ITS TRIBUTARIES, JULY 1991-MAY 1992 \\ by Colleen E. Rostad, Stephanie G. Monsterleet, LaDonna M. Bishop, and Geoffrey S. Ellis U.S. Geological Survey, Arvada, Co}

Suspended silt and colloid samples were collected from 16 sites along the Mississippi River and from some of its tributaries during July-August 1991, October-November 1991, and April-May 1992 to determine the organic carbon associated with the suspended matter. Sample collection involved pumping discharge-weighted volumes of river water from a cross section of the river into a continuous-flow centrifuge to isolate the suspended silt. Suspended colloid remaining in the aqueous phase was isolated by ultrafiltration. This is the first time that the presence of organic carbon associated with the suspended silt and colloid has been investigated along the entire reach of the Mississippi River from near Minneapolis, Minnesota, to south of New Orleans, Louisiana. The organic carbon content associated with the colloids ( 7 to 30 percent) was much higher than the organic carbon associated with the silt (2 to 5 percent). 


\section{LINEAR ALKYLBENZENE SULFONATE IN THE MISSISSIPPI RIVER}

by Charles F. Tabor, Jr. ${ }^{1}$ and Larry B. Barber, II ${ }^{1}$

Linear alkylbenzene sulfonate (LAS), the active component in most detergents, is one of the most common synthetic organic compounds found in natural waters and sediments. The estimated LAS loading in the Mississippi River basin is 3,500 kilograms per day. A detailed sampling program was undertaken to determine the occurrence and fate of LAS in a 2,900 kilometer section of the Mississippi River from Minneapolis, MN, to New orleans, LA. LAS was identified in 26 percent of the water samples at concentrations ranging from 0.1 to 12 micrograms per liter. Most dissolved LAS was associated with the sewage treatment plant outfalls of large cities along the river. LAS was identified in all of the composite bottom sediment samples analyzed at concentrations ranging from 0.01 to 0.6 milligrams per kilogram. Sulfophenyl carboxcylic acid, a LAS biodegradation intermediate, and dialkyl tetralin sulfonate, a LAS manufacturing impurity, also were identified in water and sediment samples. Although sorption to sediment removes from 5 to 30 percent of dissolved LAS, biodegradation is the most important process affecting the fate of LAS in the Mississippi River.

1 U.S. Geological Survey, Denver, Colo. 
ACCUMULATION OF ORGANOCHLORINE COMPOUNDS IN HYDRILLA

VERTICILLATA RELATIVE TO SEDIMENTS IN THE TIDAL POTOMAC RIVER

by Jessica A. Hopple ${ }^{1}$ and Gregory D. Foster ${ }^{2}$

Submersed aquatic plants are a sink for hydrophobic organic compounds. An average accumulation of 71 micrograms per kilogram of polychlorinated biphenyls was measured in Hydrilla verticillata collected from the freshwater reach of the tidal Potomac River, and an average of 53 micrograms per kilogram was measured in the bed sediment at the same location. Hydrilla verticillata accumulated an average of 1.60 micrograms per kilogram and the bed sediment accumulated an average of 0.77 micrograms per kilogram for each of the five chlorinated pesticides measured. Accumulation of chlorinated pesticides and polychlorinated biphenyls in Hydrilla verticillata was found to be a significant factor in the redistribution of contaminants in the tidal Potomac River.

${ }^{1}$ U.S. Geological Survey, Reston, VA

${ }^{2}$ George Mason University, Fairfax, VA 
DIFFICULTIES WITH INTERMEDIATE-SCALE EXPERIMENTS FOR STUDIES OF IRON CHEMISTRY IN STREAMS AFFECTED BY ACID MINE DRAINAGE By Diane M. Mcknight ${ }^{1}$, Kenneth E. Bencala ${ }^{2}$ Richard A.
Harnish ${ }^{\prime}$, and Robert L. Runkel ${ }^{\prime}$

\section{ABSTRACT}

Iron chemistry in streams affected by acidic mine drainage is driven by many dynamic processes, such as precipitation, dissolution, photoreduction of ferric iron and microbial oxidation of ferrous iron. These processes can be studied with a variety of approaches, ranging from controlled laboratory experiments to field, stream-scale perturbation experiments. We have conducted experiments that are intermediate between laboratory and field experiments using sediments and water from the Snake River. These experiments have been useful in demonstrating the general nature of iron biogeochemistry. However, difficulties reproducing results occur both within and among experiments. The heterogeneous nature of the stream sediments and seasonal variations in trace phases of iron oxides confound interpretation of the results and limit the predictive value of such experiments.

1 U.S. Geological Survey, Boulder, co

2 U.S. Geological Survey, Menlo Park, CA 


\title{
METAL CONCENTRATIONS IN SEDGES COLLECTED ON THE WETLAND RECEIVING
}

\author{
ACID MINE DRAINAGE FROM ST. KEVIN GULCH, LEADVILLE, COLORADO
}

\author{
by B. M. Erickson, ${ }^{1}$ P. H. Briggs, ${ }^{1}$ and T. R. Peacock ${ }^{1}$
}

\begin{abstract}
As of the 1989 growing season, there were no visible signs of metal stress on the wetland vegetation receiving the acid mine drainage (AMD) from of St. Kevin Gulch . However, the AMD has affected the metal concentrations of the sedges growing on the wetland. Sedge concentrations of cadmium (Cd), copper ( $\mathrm{Cu})$, iron $(\mathrm{Fe})$, lead $(\mathrm{Pb})$, manganese $(\mathrm{Mn})$, and zinc $(\mathrm{Zn})$, known to be high in the AMD waters, are higher in the area of direct inflow than the sedge baseline geometric means (GM) reported for the wetland. Concentrations higher than the GM in other areas of the wetland are evidence for other sources of contamination to the wetland. Maximum cattle dietary levels reported in the literature for $\mathrm{Cd}$ ( 0.5 milligrams per kilogram) and $\mathrm{Zn}$ (500 milligrams per kilogram) are exceeded in some areas of the wetland and could present a nutritional problem for the cattle grazing this wetland each year. Vegetation toxicity levels for $\mathrm{Cu}$ (20-100 milligrams per kilogram) and $\mathrm{Pb}$ (30-300 milligrams per kilogram) are not exceeded, but $\mathrm{Pb}$ concentrations are higher in the inflow area and may indicate accumulation is occurring. Fe deficiency, common in vegetation and foodstuffs, was not detected in the sedges of this wetland. Mn concentrations above the 500 milligrams per kilogram level reported in the literature as resulting in signs of visible stress in vegetation are exceeded in most areas of the wetland. The Fe/Mn ratio necessary for healthy vegetation (1.5 to 2.5), occurs only in the areas with the higher Fe concentrations. Presently the only element being removed from the AMD waters by the wetland is Fe. If the sedges accumulate higher levels of $\mathrm{Fe}$, the ratio of $\mathrm{Fe} / \mathrm{Mn}$ will not necessarily be improved. $\mathrm{Fe}$ and $\mathrm{Mn}$ are physiological antagonists, and at toxic Mn levels, the absorption of Fe process could reverse resulting in more stress and eventual loss of biomass.
\end{abstract}

${ }^{1}$ U.S. Geological Survey, Denver, Colo. 


\title{
URANIFEROUS WATERS OF SOUTHEASTERN COLORADO: A FUNCTION OF GEOLOGY, CLIMATE,AND LAND USE
}

\author{
by Robert A. Zielinski ${ }^{1}$ and Sigrid Asher-Bolinder ${ }^{1}$
}

The effect of local geology and land-use practices on dissolved uranium in water is indicated by reconnaissance sampling of surface waters and some springs along the Arkansas River valley of southeastern Colorado. The rate of increase of uranium concentration with distance downriver increases markedly as the river flows from predominantly undeveloped lands underlain by igneous and metamorphic rocks to agriculturally developed lands underlain by marine shale and limestone. An additional abrupt increase in dissolved uranium is observed along the section of river where discharge is greatly reduced because of extensive diversions for irrigation and where remaining flow is largely composed of irrigation return water. Water collected along this last section of river is anomalously enriched in dissolved uranium compared to the average concentration reported in water from outside of the irrigated areas. As is commonly observed, dissolved uranium shows particularly strong positive correlation with specific conductance. Uranium also shows strong positive correlations with sodium, magnesium, sulfate and chloride that contribute heavily to total dissolved solids and specific conductance in these waters. Lithium, boron, strontium and selenium are also positively correlated with uranium. The combination of natural weathering of uraniumbearing soils and sediments, extensive soil leaching by irrigation return waters, and evaporative concentration in a semiarid climate produce concentrations of dissolved uranium that may threaten local water supplies.

1 U.S Geological Survey, Denver, Colo. 


\section{Session 13--Additional Research on Toxic Substances}




\section{EFFECTS OF ORGANIC CONTAMINANTS IN MUNICIPAL AND INDUSTRIAL WASTEWATERS ON THE QUALITY OF WATER AND STREAMBED SEDIMENTS IN THE MISSISSIPPI RIVER}

by Larry B. Barber, $I^{1}$, Jerry A. Leenheer
and Mary A Noriega

Organic contaminants were measured in the Mississippi River between New Orleans, LA and Minneapolis, MN during 1991-1992 to assess spatial and temporal variability in sediment and water quality. A hierarchical analytical approach was taken in which both broad spectrum and specific compound analysis were used. Specific indicators of sewage effluents included anionic and nonionic surfactants, fecal sterols, caffeine, and fecal coliform bacteria. These compounds were detected throughout the river, with maximum concentrations occurring near major cities. Other compounds such as volatile chlorinated hydrocarbons, ethylenediaminetetraacetic acid, and trihaloalkylphosphates, which are more indicative of industrial effluents, also were detected throughout the river. Although the distribution of many compounds indicates ubiquitous contamination of the water and sediments of the Mississippi River, environmental transformation processes such volatilization, biodegradation, and sorption results in dissolved concentrations typically less than drinking water standards and toxic effect levels for aquatic organisms.

1. U.S. Geological Survey, Denver, co

2. U.S. Geological Survey, Menlo Park, CA 


\section{BIOREMEDIATION OF PETROLEUM AND METAL CONTAMINATION WITH DISSIMILATORY METAL REDUCTION}

By Derek R. Lovley 1

\section{ABSTRACT}

The possibility that the metabolism of dissimilatory metal-reducing microorganisms might be used for removing organic contaminants and metals from contaminated environments was investigated. The Fe(III) chelator, nitrilotriacetic acid (NTA) enhanced the degradation of toluene in petroleum-contaminated aquifer material in which $\mathrm{Fe}(\mathrm{III})$ reduction was the terminal electron-accepting process. Addition of $\mathrm{Fe}(\mathrm{III})$ oxide containing sediments stimulated toluene degradation in sediments that were originally methanogenic. These results suggest that increasing the availability of $\mathrm{Fe}(\mathrm{III})$ may be a useful bioremediation strategy in aquifers that are heavily contaminated with aromatic compounds. Studies on the mechanism for $\mathrm{U}(\mathrm{VI})$ reduction by Desulfovibrio vulgaris indicated that cytochrome $c 3$ is the $\mathrm{U}(\mathrm{VI})$ and $\mathrm{Cr}(\mathrm{VI})$ reductase. Cytochrome $c 3$ reduced $\mathrm{U}(\mathrm{VI})$ in uranium-contaminated mine drainage and ground water. This finding indicates that it may be possible to genetically engineer microorganisms with enhanced metal-reducing capacity. These studies demonstrate that dissimilatory metal reduction may be a useful mechanism for bioremediating organic and (or) metal contamination in some environments.

1430 National Center, U. S. Geological Survey, Reston, Va. 22092 


\title{
PATHWAYS OF METHANOGENIC BIODEGRADATION OF CREOSOTE-DERIVED AROMATIC COMPOUNDS
}

\author{
by E. Michael Godsy ${ }^{1}$, Donald F. Goerlitz ${ }^{1}$, and Dunja Grbic'-Galic ${ }^{2}$
}

The fate of organic compounds in ground water is controlled by various transport and biotransformation processes. Possibly the most important, but currently the least understood, process affecting ground-water quality is biotransformation of organic compounds by indigenous microorganisms. In this study, the degradation pathways of benzothiophene, quinoline, and naphthalene are determined on the basis of intermediate compounds that appear before and just after the onset of methanogenesis. This study revealed that the biodegradation process consists of both a major and a minor pathway. The first transformation step of the major-pathway heterocyclic compounds is oxidation and cleavage of the heterocyclic ring. After cleavage of this ring, the substituent side chains and the remaining homocyclic ring are subjected to various reactions, including oxidation, decarboxylation, desulfurylation or ammonification, and O-methylation. These reactions are followed by the reduction of the homocyclic ring, cleavage of this ring, $\beta$-oxidation, and mineralization. The major pathway intersects both the benzoic acid and phenol methanogenic-degradation pathways. A minor pathway for heterocyclic compounds starting with the oxidation of the homocyclic ring with subsequent ring reduction, ring cleavage, degradation of the remaining heterocyclic ring, and mineralization also was observed.

\footnotetext{
${ }^{1}$ U.S. Geological Survey, Menlo Park, CA

${ }^{2}$ Stanford University, Stanford, CA
} 


\title{
Reaction of arsenic minerals and gold ores with alkaline cyanide solutions
}

\author{
by Walter H. Ficklin1, Geoffrey S. Plumlee ${ }^{1}$, and John B. McHugh ${ }^{1}$
}

Gold ores often contain significant quantities of arsenic (As). The As may occur in several different mineral forms and/or oxidation states. The most common As minerals are arsenopyrite (FeAsS), orpiment $\left(\mathrm{As}_{2} \mathrm{~S}_{3}\right)$, and realgar ( $\mathrm{AsS}$ ) but some deposits may contain oxidized forms of arsenic (arsenates) and more exotic minerals such as enargite $\left(\mathrm{Cu}_{3} \mathrm{AsS}_{4}\right)$. During heap leaching with alkaline cyanide solutions some As is dissolved from these minerals. At $\mathrm{pH}$ values equivalent to those found in heap-leach solutions, the presence of cyanide increases the concentration of arsenic that dissolves by a factor of 4 to 100 for various forms of As. Formation of thiocyanate is one factor that enhances the dissolution of arsenic from sulfide minerals. Orpiment reacts more strongly with cyanide solutions than realgar and much more strongly than arsenopyrite.

1 U.S. Geological Survey, Lakewood, Colorado 


\section{Session 14--Plains and Nonpoint Source Contamination}


FATE AND TRANSPORT OF ATRAZINE AT THE PLAINS, GEORGIA, GROUND-WATER STUDY SITE

\author{
R. A. Leonard', L. R. Marti' ${ }^{1}$, D. W. Hicks², and J. B. McConnell ${ }^{2}$
}

Cooperative research between the U.S. Geological Survey, U.S. Department of Agriculture, Agricultural Research Service, and U.S. Environmental Protection Agency was initiated in 1986 near Plains, Georgia, to define processes that affect movement and fate of agricultural chemicals and to establish a common comprehensive data base for development and testing of mathematical models. Data from one crop cycle (mid-March 1992 to mid-March 1993) are summarized to illustrate the fate and present state of atrazine in the system after four annual treatments at normal application rates for corn. In 1992, parent atrazine dissipated in the root zone with a half-life of about 18 days. The atrazine metabolites, desethylatrazine (DEA) and desisopropylatrazine (DIA) accumulated in the root zone to a maximum 27 days after application, DEA was the primary metabolite. The maximum DEA/atrazine ratio was 0.640 days after atrazine application. After crop harvest in mid-July 1992, atrazine, DEA and traces of DIA were detected throughout the unsaturated zone to depths of 8.7 meters. Because the area had been treated with atrazine during the previous 3 years, the atrazine found could not be associated with a particular application. By March 1993, atrazine in the unsaturated zone had decreased from an estimated 360 grams per hectare to 100 grams per hectare. Atrazine and DEA in ground water, at the time of sampling, were at greater concentrations downgradient from the treated area, with the maximum concentrations about 60 meters downgradient from the treated plot boundary. Traces of atrazine and DEA were detected 280 meters downgradient from the plot. DEA/atrazine ratios were slightly higher in ground water compared to the unsaturated zone, possibly indicating continued transformation along the ground-water flow path.

'U. S. Department of Agriculture, Agricultural Research Service, Southeast Watershed Research Laboratory, P. O. Box 946, Tifton, GA

${ }^{2}$ U. S. Geological Survey, 3039 Amwiler Road, Atlanta, GA 


\section{UNSATURATED ZONE TRANSPORT AT THE PLAINS, GEORGIA, FIELD SITE}

by David D. Bosch ${ }^{1}$, Ralph A. Leonard ${ }^{1}$, and Robert K. Hubbard

Soil-water and solute-transport data have been collected over three years on a 0.81 ha field site located near Plains, Georgia. Soil cores collected from the root and vadose zone show extreme variability in movement and transport of applied bromide $\left(\mathrm{Br}^{-}\right)$tracer. The Groundwater Loading Effects of Agricultural Management Systems - Finite Element Solute Transport (GLEAMS-FEST) root-vadose zone model was used to simulate $\mathrm{Br}^{-}$ transport below the site. Comparison of simulated concentrations to horizontally averaged profile concentrations show good agreement for year one but poor agreement thereafter, probably due to inaccurate estimates of hydraulic parameters in deeper parts of the vadose zone. Because of extreme variability in transport data, profile-averaged concentrations may not be a realistic representation of the sample data.

U.S. Department of Agriculture, Agricultural Research Service, Southeast Watershed Research Laboratory, Tifton, Georgia 31793 


\title{
TWO-DIMENSIONAL DISTRIBUTION OF A BROMIDE TRACER IN THE UNSATURATED ZONE AT THE PLAINS, GEORGIA, RESEARCH SITE
}

\author{
by D.W. Hicks ${ }^{1}$, J.B. McConnell1, H.H. Persinger ${ }^{1}$, J.D. Scholz ${ }^{1}$, and R.K. Hubbard ${ }^{2}$
}

\begin{abstract}
A cooperative research investigation was initiated in 1986 near Plains, Georgia, by the U.S. Geological Survey; and the U.S. Department of Agriculture, Agricultural Research Service, to describe the processes that affect the movement and fate of nitrogen fertilizers; the pesticides atrazine, alachlor, and carbofuran; and a potassium bromide tracer in the plant-root, unsaturated, and saturated zones. As a result of ongoing research, in 1991 emphasis was placed on field-scale research to develop a better understanding of the physical and chemical processes that occur as water flows through variably saturated or unsaturated porous media. Data collected along a farmed, 420 -foot-long transect were used to define and evaluate the factors that control the rate of movement and distribution of agricultural chemicals in the unsaturated zone. It was hypothesized that lateral (non-vertical) migration of soil water and chemicals at the interface between permeable and less permeable material might account for a significant part of the dispersion of agricultural chemicals in the unsaturated zone.

Preliminary results of this investigation indicate that the fluctuations of soil water and concentrations of bromide at specific depths and locations along the transect are a function of the relative vertical hydraulic conductivities of the adjacent soil layers. Soil heterogeneity substantially affects the migration rates and distribution of the bromide tracer in the unsaturated zone. Lateral flow along the interface of permeable and less permeable soil may account for the rapid fluctuations observed in matric suction and the distribution of the tracer in the unsaturated zone. For this reason, the deterministic methods that are routinely used in numerical simulation of fate and transport are not valid in the vast majority of field conditions when applied in sloping, structured, variably saturated porous media.
\end{abstract}

\footnotetext{
${ }^{1}$ U.S. Geological Survey, Atlanta, Georgia

${ }^{2}$ U.S. Department of Agriculture, Agricultural Research Service, Tifton, Georgia
} 


\title{
Modeling Statistical Relations Among Shallow Ground-Water Quality, Human Activities, Land Use, and Thickness of the Unsaturated Zone on Long Island, New York
}

\author{
by Paul E. Stackelberg ${ }^{1}$ and David A.V. Eckhardt ${ }^{2}$
}

\begin{abstract}
Water-quality data from 90 shallow observation wells in five areas of differing land use in Nassau and Suffolk Counties were used to develop statistical models that relate shallow ground-water quality to variables representing human activities and hydrogeologic conditions. The five study areas represent the full range of land uses in the two-county area and lie along the regional ground-water divide, where ground-water has a vertically downward component and thus recharges deep zones of the aquifer system.

Maximum-likelihood logistic-regression analysis of explanatory variables that describe the degree and type of human activities and hydrogeologic conditions at the 90 well sites was used to develop statistical models that can predict the probability of the presence of contaminants in shallow ground water within the two-county area. Variables found useful for representing human activities and hydrogeologic conditions include (1) population density within a 1/2-mile radius of each well, (2) percentages of land-use categories within the same area, and (3) thickness of the unsaturated zone at each well site. One model that relates the probability of the presence of volatile organic compounds (VOC's) at concentrations of at least 1 microgram per liter to commercial and high- and medium-density residential land was selected to illustrate model application and testing procedures. Resulting predictions were compared with an independent set of water-quality data from 378 wells in Nassau and Suffolk Counties. The comparison indicates that VOC's are more prevalent in areas with relatively little commercial and dense residential land than predicted by data from the five study areas.
\end{abstract}

${ }^{1}$ U.S. Geological Survey, Syosset, N.Y.

${ }^{2}$ U.S. Geological Survey, Ithaca, N.Y. 


\title{
USE OF FLOWPATH SIMULATION TO DETERMINE CONTRIBUTING AREAS AND TRAVEL TIMES OF NONPOINT-SOURCE GROUND-WATER CONTAMINATION, GLOUCESTER COUNTY, NEW JERSEY
}

\author{
by Anthony S. Navoy \\ U.S. Geological Survey, West Trenton, N. J.
}

The area of direct surficial recharge, potentially affected by nonpoint-source contamination, to the Potomac-Raritan-Magothy aquifer system in Gloucester County, New Jersey, extends a maximum of 0.5 to 2 miles downdip from the outcrop area as determined by use of a finely discretized ground-water-flow model and flow-path simulation by use of particle-tracking analysis. The areas contributing water to three water-supply wells, determined by simulation, were found to contain chemical-product-manufacturing or petroleum-refining land use. A relatively short minimum travel time of 30 years between the petroleum-refining land use and one of the wells indicates that contamination by volatile organic compounds is likely. The minimum travel times of greater than 50 years to the other two wells indicate that, to date, contamination by volatile organic compounds is not likely. These interpretations are consistent with available water-quality data. The results of the analysis also indicate that the two wells heretofore unaffected by contamination probably will be affected by contamination in the future and that the concentrations of volatile organic compounds in water from the affected well are likely to increase. The method of analysis used in this investigation could be applied to other locales provided that a finely discretized ground-water-flow model and high-resolution land-use data are available. 
Session 15--Pinal Creek 
HYDROLOGIC AND GEOCHEMICAL FACTORS AFFECTING METAL-CONTAMINANT

TRANSPORT IN PINAL CREEK BASIN NEAR GLOBE, ARIZONA

By James G. Brown ${ }^{1}$ and Judson W. Harvey ${ }^{2}$

\section{ABSTRACT}

Acidic mine drainage from copper mining in the Pinal Creek basin has contaminated the regional aquifer. Chemical reactions neutralize the contaminant plume as it moves downgradient. Neutralized contamination subsequently surfaces in a perennial reach of Pinal Creek and equilibrates with the atmosphere, causing $\mathrm{pH}$ to rise and manganese minerals to precipitate on the streambed. Ongoing research at the site is focused on ground-water hydrology and geochemistry, metal transport, and interactions between shallow ground water and streamflow.

Field and laboratory experiments will attempt to identify the reduction(s) that balance the oxidation of iron in the aquifer. Reactive-transport simulations of plume evolution and remediation will identify the important processes and reactions that produced the observed conditions in the plume. Measurements of gravity change and ground-water level change at project wells may provide refined estimates of aquifer specific yield for use in reactivetransport simulations. Estimates of ground-water ages by chlorofluorocarbon age-dating techniques may improve estimates of traveltimes and reaction rates of contaminants in ground water.

Mechanisms of trace-metal scavenging by manganese carbonates, manganese oxides, and iron oxides in the perennial stream are being investigated, and partitioning coefficients are being estimated to constrain hydrogeochemical modeling. A coupled aquifer-stream mass-balance approach has been used to constrain effective rates of solid-aqueous partitioning of manganese, iron, nickel, copper, and cobalt. Tracer experiments are being undertaken to distinguish reactions occurring in near-stream ground water from reactions in streamflow.

\footnotetext{
1. U.S. Geological Survey, Tucson, Arizona

2. U.S. Geological Survey, Menlo Park, California
} 


\title{
UNSATURATED ZONE DIFFUSION OF CARBON DIOXIDE AND OXYGEN IN THE PINAL CREEK BASIN, ARIZONA
}

\author{
by Pierre D. Glynn ${ }^{1}$ and Eurybiades Busenberg 1
}

Unsaturated-zone gases were sampled in November 1991 at two sites in the Pinal Creek basin, above the acidic to partially neutralized ground-water-contaminant plume. The gases were analyzed for carbon dioxide $\left(\mathrm{CO}_{2}\right)$, oxygen $\left(\mathrm{O}_{2}\right)$, nitrogen and argon. The isotopic composition of the $\mathrm{CO}_{2}$ gas also was measured. Results show a linear $\mathrm{CO}_{2}$ and $\mathrm{O}_{2}$ gradient as well as a linear gradient in the carbon isotope composition of the $\mathrm{CO}_{2}$. An oxygen flux towards the water table of approximately $1.1 \times 10^{-2}\left(\mathrm{~mol} / \mathrm{m}^{2}\right) / \mathrm{d}($ moles per square meter per day) is estimated. This oxygen flux is probably caused by the reaction of dissolved oxygen with reduced manganese and iron in the ground water. A steady-state flux of approximately $9 \times 10^{-3}\left(\mathrm{~mol} / \mathrm{m}^{2}\right) / \mathrm{d}$ of carbon dioxide through the unsaturated zone can also be calculated. The $\mathrm{CO}_{2}$ flux is thought to emanate from the ground-water table. The reaction of acidic contaminated ground water with carbonate minerals produces ground waters with high equilibrium partial pressures of $\mathrm{CO}_{2}$ relative to the unsaturated zone atmosphere. The high carbon-13/carbon- $12\left({ }^{13} \mathrm{C} / 12 \mathrm{C}\right)$ ratios of the unsaturated zone $\mathrm{CO}_{2}$ (as high as -10.75 per mil $\delta 13 \mathrm{C}$ with respect to the Vienna Pee Dee Belemnite standard), and the increase in the ${ }^{13} \mathrm{C} / 12 \mathrm{C}$ ratio with increasing $\mathrm{CO}_{2}$ concentrations, suggests that degradation of organic matter and root respiration in the unsaturated zone are not contributing significantly to the $\mathrm{CO}_{2}$ flux. Field measurements show a difference of close to 4.4 per mil in $\delta^{13} \mathrm{C}$ between the ${ }^{13} \mathrm{C}$ enriched $\mathrm{CO}_{2}$ sampled just above the water table and $\mathrm{CO}_{2}$ sampled 0.46 meters below the ground surface. A theoretical model constructed assuming (1) steady-state diffusion of $\mathrm{CO}_{2}$ from the water table, (2) a constant ${ }^{13} \mathrm{C} /{ }^{12} \mathrm{C}$ flux ratio determined by the isotopic composition of the $\mathrm{CO}_{2}$ exsolving from the water table and (3) a fixed ${ }^{13} \mathrm{C} / 12 \mathrm{C}$ ratio at the ground surface, predicts a difference of close to 4.4 per mil ${ }^{13} \mathrm{C}$ fractionation between $\mathrm{CO}_{2}$ built up just above the water table and the $\mathrm{CO}_{2}$ coming out of the ground surface. Further research is needed to reconcile our field observations with our theoretical diffusion model.

1 U.S. Geological Survey, 12201 Sunrise Valley Drive, MS 432, Reston, VA 22092 


\title{
CHEMICAL PROCESSES IN MANGANESE OXIDE AND CARBONATE PRECIPITATION IN PINAL CREEK, ARIZONA
}

\author{
by John D. Hem, and Carol J. Lind
}

Two water samples from well 503 near the head of the perennial reach of Pinal Creek and one sample of surface flow at the setka Ranch crossing about 2 kilometers downstream from the well were used as the manganese-bearing solution in automated $\mathrm{pH}$-stat titration with a 0.10 molar $\mathrm{NaOH}$ solution while bubbling $\mathrm{CO}_{2}$-free air into the mixture. The three samples had manganese concentrations ranging from 63 to $94 \mathrm{mg} / \mathrm{L}$ and dissolved solids concentrations ranging from of 3,500 to $3,570 \mathrm{mg} / \mathrm{L}$, mostly consisting of $\mathrm{Ca}$ and $\mathrm{SO}_{4}$. The ground-water samples initially were about $5 \times 10^{-3}$ molar in undissociated dissolved $\mathrm{CO}_{2}$ and had $\mathrm{pH}$ 's near 6. The creek water had a $\mathrm{pH}$ near 7 and a $\mathrm{CO}_{2}$ concentration smaller than $10^{-3}$ molar. Titration of one groundwater sample done without removing the dissolved $\mathrm{CO}_{2}$ produced a mixture of hausmannite $\left(\mathrm{Mn}_{3} \mathrm{O}_{4}\right)$ and kutnahorite $\left(\operatorname{CaMn}\left(\mathrm{CO}_{3}\right)_{2}\right)$. The other two samples were treated to decrease the dissolved $\mathrm{CO}_{2}$ species before titration. One of these samples yielded mainly hausmannite during titration that altered on aging to manganite $(\mathrm{MnOOH})$. The other yielded a mixture of oxides that altered on aging to a mixed $\mathrm{Ca}+\mathrm{Mn}$ species similar to todorokite ( $\left(\mathrm{Mn}^{2+}\right.$, Ca) $\mathrm{Mn}^{4+}{ }_{5} \mathrm{O}_{11} \cdot 4 \mathrm{H}_{2} \mathrm{O}$ ) in which most of the manganese is in the $4+$ oxidation state. X-ray-diffraction studies of precipitates from Pinal creek identified kutnahorite in carbonate cemented crusts near the head of perennial flow. The mixed $\mathrm{Ca}+\mathrm{Mn}^{4+}$ oxides also were identified near the head of perennial flow and in black precipitates farther downstream.

U.S. Geological Survey, Menlo Park, CA 


\title{
INTERACTIONS BETWEEN SHALLOW GROUND WATER AND SURFACE WATER THAT AFFECT METAL TRANSPORT IN PINAL CREEK, ARIZONA
}

\author{
By Judson W. Harvey ${ }^{1}$, Christopher C. Fuller ${ }^{1}$, and Brian J. Wagner ${ }^{1}$
}

Solute transport was investigated in shallow groundwater and surface water along a $500-\mathrm{m}$ reach of the perennial stream in Pinal Creek basin. A bromide tracer injection in the stream was conducted to quantify ground water inflow and streamwater/ streambed-water exchange. We determined that respective gains and losses in $\mathrm{Fe}$ (iron) and Mn (manganese) in solution occurred in ground water discharging laterally through bank seeps into the stream, and not in ground water discharging vertically from below the active channel, or in the active surface channel itself. Aqueous metal concentrations measured in shallow ground water varied significantly with position across the narrow channel at Pinal Creek. Concentrations of Fe were 20 to 50 -fold higher in shallow ground water discharging laterally through channel banks compared to ground water discharging vertically from beneath the stream. Mn was 25 percent lower in bank seepage compared to subchannel ground water. Crosschannel variability in metal concentrations in contaminated ground water could not be explained by differential dilution of ground water discharging laterally to the channel versus vertically through the streambed. Mass balance calculations for the $500-\mathrm{m}$ reach of stream and shallow ground water aquifer verified that $\mathrm{Fe}$ and $\mathrm{Mn}$ dynamics in bank seepage were sufficient to affect downstream concentrations of those constituents. We hypothesize that microbial processes in channel banks drive reductive dissolution of solid phase $\mathrm{Fe}$ in ground water discharging laterally through banks, but not in subchannel ground water. The mechanism of Mn loss in this channel reach appeared to be sorption of $\mathrm{Mn}^{2+}$ on Fe-oxyhydroxides, which form where ground water emerges from bank-seeps.

${ }^{1}$ U.S. Geological Survey, Menlo Park, Calif. 


\section{Session 16--Poster Presentations}

\section{Additional Research on Toxic Substances}

\section{Plains and Nonpoint Source Contamination}

\section{Pinal Creek}




\title{
Anaerobic Growth of Bacterial Strain SES3 with Selenate as the Electron Acceptor
}

\author{
By Jodi Switzer Blum ${ }^{1}$, Charles W. Culbertson ${ }^{1}$, and Ronald S. Oremland ${ }^{1}$
}

\begin{abstract}
The bacterial strain SES3 is capable of growth with selenate, nitrate, or Fe (III) as electron acceptors, and lactate as an electron donor. Selenate is reduced through selenite to elemental selenium, whereas nitrate was reduced through nitrite to ammonia, and Fe(III) was reduced to $\mathrm{Fe}$ (II). Lactate was oxidized to $\mathrm{CO}_{2}$ and acetate in an approximately 1:1 ratio. Results of washedcell experiments comparing nitrate and selenate reduction in either nitrate-grown or selenate-grown cells indicated that separate enzyme systems performed the reductions. Washed-cell experiments using uniformly labelled, [U- ${ }^{14} \mathrm{C}$ ] lactate, showed that fumarate, arsenate, and $\mathrm{O}_{2}$ also functioned as electron acceptors. The respiratory inhibitors azide, carbonyl cyanide m-chlorophenylhydrazone (CCCP), and dinitrophenol (DNP) inhibited both selenate and nitrate reduction in washed-cell suspensions.
\end{abstract}

${ }^{1}$ U.S. Geological Survey, Menlo Park, Calif. 


\title{
MICROBIAL DEGRADATION OF NITROTOLUENES
}

\section{IN SURFACE SOILS AND AQUIFER SEDIMENTS,}

WELDON SPRING, MISSOURI

\section{BY FRANCIS H. CHAPELLE ${ }^{1}$ AND PAUL M. BRADLEY ${ }^{1}$}

\begin{abstract}
Surface soils and underlying aquifer material from a nitrotoluenecontaminated site at Weldon Spring, Missouri were evaluated for the potential of indigenous microorganisms to transform 2,4,6-trinitrotoluene (2,4,6-TNT), 2,4dinitrotoluene (2,4-DNT) and 2,6-dinitrotoluene (2,6-DNT). The results indicate that the microbial communities are capable of rapidly metabolizing 2,4-DNT, 2,6-DNT and 2,4,6-TNT. In most cases, complete dissappearance of the source compound was achieved within 20 to $\mathbf{7 0}$ days. Radiotracer experiments confirmed that carbon dioxide was a major endproduct of microbial degradation. These results indicate that in situ bioremediation may be a viable alternative for treating contaminated soils and ground water. Furthermore, the results suggest that the presently observed nitroaromatics contamination of ground water is unlikely to be a relic of past (50 years BP) wastedisposal practices, but rather reflects continual leaching of nitroaromatics from contaminated soils.
\end{abstract}

${ }^{1}$ U.S. Geological Survey, Columbia, South Carolina 


\title{
CHEMICAL, ISOTOPIC, AND MICROBIOLOGICAL EVIDENCE FOR DENITRIFICATION DURING TRANSPORT OF DOMESTIC WASTEWATER THROUGH A THICK UNSATURATED ZONE IN THE MOJAVE DESERT
}

\author{
by Roy A. Schroeder ${ }^{1}$, Peter Martin ${ }^{1}$, and J.K. Böhlke
}

Septic-tank wastewater disposed in 30 -foot-deep seepage pits (dry wells) at 46,000 residences is estimated to equal about 18 percent of natural recharge to the sole-source aquifer beneath the upper Mojave River Basin, which is rapidly becoming urbanized, in the high desert northeast of Los Angeles. Nitrogen in the downward-infiltrating wastewaters represents a significant potential source of nitrate contamination to underlying ground water, but increases in nitrate concentration in ground water have not yet been observed. The low nitrate concentration in the ground water may be the result of lateral dispersion in the unsaturated zone, dilution below the water table, or denitrification of wastewater nitrate in the unsaturated zone.

Measured vertical rates of movement of wastewater fronts through the unsaturated zone at three newly occupied residences ranged from 0.07 to 1 foot per day. Those measurements, along with moisture-content profiles at older residences, indicate that some wastewater has reached the water table beneath communities that are older than 5 to 10 years. As wastewater percolates from seepage pits into the unsaturated zone, reduced nitrogen is converted rapidly to nitrate at shallow depths. Analyses of water extracts of soil cores and of soil moisture from suction lysimeters deep beneath seepage pits at several residences indicate that nitrate concentrations commonly decrease with depth. The largest nitrate decreases seem to coincide with increased content of fine-grained sediments or proximity to the water table. Nitrate-reducing bacteria were found in soil cores collected from two residences. Between lysimeters at 160 and 199 feet at one residence, the decrease in nitrate concentration coincided with a large increase in sulfate, decrease in alkalinity, and increase in $\delta^{15} \mathrm{~N}$ in nitrate. Those data are consistent with denitrification by oxidation of iron sulfide to produce ferric oxides; but if such a reaction occurs, it must be in domains that are small in comparison with the sampled volumes because the waters also contain substantial quantities of dissolved oxygen. The predominantly low nitrate concentrations in the area's ground water are consistent with the operation of a nitrogen-removal mechanism, possibly denitrification, as wastewater moves through an unsaturated zone that averages 150 feet in thickness. However, the reducing capacity of the sediments to maintain denitrification is not known.

\footnotetext{
${ }^{1}$ U.S. Geological Survey, San Diego, CA

${ }^{2}$ U.S. Geological Survey, 431 National Center, Reston, VA
} 
POTENTIAL ANHYDRITE PRECIPITATION ASSOCIATED WITH DEEP INJECTION OF GROUND-WATER BRINE FROM PARADOX VALLEY, COLORADO

by Yousif K. Kharaka, William C. Evans, Gil Ambats and James J. Thordsen

Seepage and discharge of ground-water brine into the Dolores River in Paradox Valley, a collapsed diapiric salt anticline located in southwestern colorado, increase the dissolved-solids load of the Colorado River annually by about $2.0 \times 10^{8} \mathrm{~kg}$. In order to abate this natural contamination, the U.S. Bureau of Reclamation plans to pump about $3,540 \mathrm{~m}^{3} / \mathrm{d}$ of brine from 12 shallow wells located along the Dolores River. brine, with a salinity of $250,000 \mathrm{mg} / \mathrm{L}$, will be piped to the deepest $(4.88 \mathrm{~km})$ injection well in the world, and injected mainly into the Mississippian Leadville Formation.

Results of geochemical modeling indicate and water-rock experiments confirm that a huge mass of anhydrite, about 10,000 $\mathrm{kg} / \mathrm{d}$, likely will precipitate from this brine, when heated to $120^{\circ} \mathrm{C}$ at 500 bar--the temperature and pressure conditions in the Leadville aquifer. Precipitation of anhydrite could increase by a factor of two or more if the injected brine were allowed to $\mathrm{mix}$ with the highly incompatible formation water of the Leadville aquifer and if, as expected, the Mg in this brine dolomitizes the calcite of the aquifer. Dilution of the brine with river water, precipitation of its $\mathrm{SO}_{4}$, and (or) addition of precipitation inhibitors prior to injection are possible remedial actions.

U.S. Geological Survey, Menlo Park, CA 


\title{
APPARENT SOLUTE DISPERSION IN AN ALLUVIAL-AQUIFER/STREAM SYSTEM
}

\author{
by J. Jeffrey Starn ${ }^{1}$
}

In simulations of solute transport, the dispersion coefficient characterizes the spreading and mixing of the solute due to variations in ground-water flow velocity that are not explicitly included in the simulation. Although usually considered to be the result of variability in hydraulic conductivity, dispersion also can result from variations in the direction of ground-water flow. A computer simulation of ground-water flow and solute transport in an alluvial aquifer/stream system shows that fluctuations in river stage and subsequent changes in the direction of ground-water flow in the aquifer cause an increase in apparent dispersion. Solute plumes in an alluvial aquifer near a river move more slowly and become more dilute as a result of ground-water/surface-water interaction than if this interaction is not considered.

${ }^{1}$ U.S. Geological Survey, 2301 Bradley Avenue, Louisville, Kentucky 40217 


\title{
DEPLETION OF NITROGEN-BEARING EXPLOSIVES WASTES IN A SHALLOW GROUND-WATER PLUME NEAR HAWTHORNE, NEVADA
}

\author{
by A.S. Van Denburgh ${ }^{1}$, D.F. Goerlitz ${ }^{2}$, and E.M. Godsy ${ }^{2}$
}

Liquid explosives wastes from the emptying and washout of military projectile and bomb casings were discharged into unlined disposal pits north of Hawthorne, Nevada. The explosives involved at this arid study area were ammonium picrate, during 1952-58, and trinitrotoluene (TNT) plus ammonium nitrate, during 1964-68. Percolation from the pits entered unconsolidated, heterogeneous sedimentary deposits in which clay- to gravelsize particles predominate. The water table at and downgradient from the pits was from 1-1/2 to 6-1/2 meters below land surface during the study. The shallow ground water moves northwestward at an average linear velocity of about 130 meters per year.

A shallow plume of ground water containing 3 to 130 milligrams per liter of dissolved-nitrogen species, as nitrogen, extended more than 1,700 meters northwest of the northernmost pits. Either ammonium or nitrate dominated at sample sites within 300 meters of the pits; farther downgradient in the plume, nitrate was the most abundant. Overall, the plume contained about 3 megagrams of dissolved nitrogen downgradient from the pits. The proportions of sodium and bicarbonate ions increased downgradient, relative to chloride and sulfate ions. Saturated sedimentary deposits within the plume generally had greater concentrations of organic nitrogen, ammonium, and organic carbon than did the adjacent sediments.

The maximum linear velocities for the dissolved explosives-waste components (a measure of their mobility) ranged from more than 77 meters per year for nitrate to less than 20 meters per year for picrate, with velocities of TNT and ammonium in between. The downgradient movement of nitrate may not have been impeded by microbiological or geochemical processes. For the other dissolved components, however, the following depletion mechanisms are proposed: TNT, microbial transformation to inorganic nitrogen and carbon species, and probable sorption of organic transformation products; ammonium, sorption, and probable oxidation by nitrifying bacteria; and picrate, microbial alteration to picramic acid, then mineralization to inorganic nitrogen and carbon species. The reactions that depleted TNT, ammonium, and picrate in the ground water may also have enriched the proportions of sodium and bicarbonate ions in the plume. Overall, the Hawthorne study shows that natural microbiological and geochemical processes can degrade or retard the transport of large quantities of toxic, chemically complex, nitrogen-rich explosives wastes over distances of only hundreds of meters, leaving nitrate as the only residual nitrogen-bearing component of the ground-water plume.

1 U.S. Geological Survey, Carson City, NV

2 U.S. Geological Survey, Menlo Park, CA 


\title{
SPATIAL VARIABILITY OF SOIL PROPERTIES AFFECTING CHEMICAL TRANSPORT AT THE PLAINS, GEORGIA, RESEARCH SITE
}

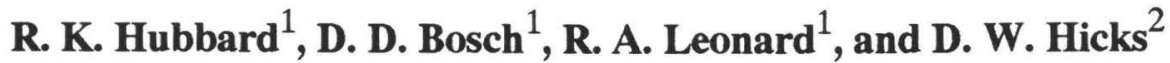

\begin{abstract}
A study was conducted on a 0.81 -ha site near Plains, Georgia, to determine transport rates of water and applied agricultural chemicals to ground water in a recharge area of the Coastal Plain. As part of the study, soil cores were collected from the root and vadose zone to a depth of $914 \mathrm{~cm}$ ( $30 \mathrm{ft}$ ). Cores were collected from 12 locations within the site to determine spatial variability of the soil physical properties. Measurements of core samples were made of particle size distribution, vertical saturated hydraulic conductivity, bulk density, and soil moisture retention. Measured soil moisture retention was compared with soil moisture retention predicted from equations based on particle size distribution and bulk density. Analyses of the soil samples showed that the physical properties varied both vertically and laterally. The soil has a sandy texture at the surface, has increased clay content from 91 to $366 \mathrm{~cm}$ ( 3 to $12 \mathrm{ft}$ ) deep, and then is very sandy to a depth of $914 \mathrm{~cm} \mathrm{(30} \mathrm{ft).} \mathrm{Laterally,} \mathrm{the} \mathrm{plot} \mathrm{varies} \mathrm{in} \mathrm{clay} \mathrm{content} \mathrm{in} \mathrm{the} 91$ to $366 \mathrm{~cm}$ ( 3 to $12 \mathrm{ft}$ ) depth interval from the eastern to the western side, with the northeastern corner having the highest clay content. Lower vertical saturated hydraulic conductivities and higher soil moisture retention and bulk densities are associated with increasing clay content. The comparisons between measured and predicted volumetric-water content show that the equations adequately predict the relative magnitude of the volumetric-water content, but that absolute predictions lack precision.
\end{abstract}

${ }^{1}$ U.S. Department of Agriculture, Agricultural Research Service, Southeast Watershed Research Laboratory, P.O. Box 946, Tifton, GA 31793

${ }^{2}$ U.S. Geolgoical Survey, 3039 Amwiler Road, Atlanta, GA 30360-2824 


\title{
A REVIEW OF METHODS FOR ASSESSING THE POTENTIAL FOR REGIONAL GROUND-WATER CONTAMINATION
}

\author{
by David R. Soller ${ }^{1}$
}

The potential for ground-water contamination, or the sensitivity of an area to ground-water contamination, can be estimated by a quantitative, deterministic model that predicts fate and transport of water and contaminants locally, or by a broad, regional qualitative model. Although regional models do not predict ground-water contamination at specific sites as accurately as do the local models, the former are useful tools for regional planning and research. All regional models depict relative contamination potential. Some models focus on contamination potential of ground water in aquifers, either at the land surface or confined beneath low-permeability sediments, whereas other models focus on ground water at the unconfined water table. For a given area, the focus of ground-water protection efforts will determine which models are most appropriate. Some regional models use dimensionless numbers and weighting factors to derive a relative measure of contamination potential, whereas others assemble source data into a composite map and rank the resulting map units for contamination potential according to a set of rules. Both approaches have certain advantages. However, because most contamination potential maps in the area considered (Central United States) show roughly similar patterns of contamination potential, some models may be more practical than others. For example, if simple models give results similar to models requiring cumbersome numeric manipulation of data, there is little justification for the effort needed to execute the more complex model. Availability of information required by a model also should determine its utility. Regional, stochastic models that provide actual, not relative, predictions of contamination potential are needed. Those models should consider the uncertainty in source information in order to estimate contamination potential with specified levels of uncertainty.

${ }^{1}$ U.S. Geological Survey, Rèston, VA 


\title{
Evaluating the Effect of Land Use and Sampling Depth on Ground-Water Quality, Long Island, New York
}

\author{
By Paul E. Stackelberg ${ }^{1}$
}

\begin{abstract}
The effect of nonpoint-source contamination was statistically evaluated through a comparison of waterquality data collected from two depth intervals at 153 wells in five areas of differing land use on Long Island. Each area was delineated to represent a predominant land use; the areas were categorized as (1) suburban with long-term sewering, (2) suburban with recent sewering, (3) suburban without sewers, (4) agricultural, and (5) undeveloped. The depth zones were delineated on the basis of estimated traveltime of ground water along vertical flow paths from the water table to each well screen's midpoint. Wells were classified as shallow (estimated traveltimes of less than 10 years) or intermediate (estimated traveltimes between 10 and 100 years).

Concentrations of several inorganic constituents and values of field properties were found to differ significantly among land-use areas and depth zones. Median constituent concentrations tend to be (1) highest, and the concentration ranges the widest, in samples from the agricultural area, (2) lowest, and the concentration ranges the smallest, in samples from the undeveloped area, and (3) intermediate to high in samples from the suburban areas. Volatile organic compounds (VOC's) were detected only in the suburban areas. A common source of nonpoint-source contamination in agricultural and residential areas is fertilizers used on commercial crops, lawns, gardens, and golf courses. Other sources of inorganic contaminants and VOC's in residential areas include (1) effluent from cesspools, septic tanks, and leaking sewers, (2) road-deicing salts, and (3) runoff contaminated by road residues and by chemicals commonly used at industrial and commercial facilities. A decrease in concentrations of most inorganic constituents with depth is attributed to (1) physical and chemical reactions that remove constituents from solution, and (2) dilution by advection and hydrodynamic dispersion along flow paths.
\end{abstract}

${ }^{1}$ U.S. Geological Survey, Syosset, N.Y. 


\title{
VULNERABILITY OF WATER FROM PUBLIC SUPPLY WELLS TO CONTAMINATION BY PESTICIDES, POTOMAC-RARITAN-MAGOTHY AQUIFER SYSTEM, NEW JERSEY COASTAL PLAIN
}

\author{
Eric F. Vowinkel ${ }^{1}$
}

\begin{abstract}
A numerical rating model used in conjunction with hydrogeologic, land-use, and waterquality data stored in a geographic information system was developed to rank 558 public supply wells screened in the Potomac-Raritan-Magothy aquifer system in the New Jersey Coastal Plain into groups of high, medium, and low vulnerability to contamination by pesticides. The vulnerability of water from public supply wells to contamination by pesticides is defined by variables describing the (1) sensitivity of the aquifer to contamination and (2) intensity of pesticide use in areas where the aquifer is sensitive. The results of the model indicated that 305 wells were of low vulnerability, 237 were moderately vulnerable, and 16 were highly vulnerable to contamination. Because analyses for pesticides in water samples are scarce, the concentration of nitrate in water samples was used as a surrogate to develop and test the accuracy of the model. Results of statistical tests indicate that the concentration of nitrate is a significant indicator of aquifer sensitivity, pesticide-use intensity, and the presence of pesticides in ground water. Results of the rating model indicate that water from only 1 of the 138 sampled wells that were ranked as low vulnerability contained nitrate as nitrogen in concentrations larger than 0.5 milligrams/L. Concentrations of nitrate in water samples were significantly larger in the medium- and high-vulnerability groups than in the low-vulnerability group.
\end{abstract}

${ }^{1}$ U.S. Geological Survey, Mountain View Office Park

810 Bear Tavern Road, Suite 206

West Trenton, New Jersey 08628 


\title{
DISSOLVED GAS AND CHLOROFLUOROCARBON CONTENT OF GROUND WATERS IN THE PINAL CREEK BASIN, ARIZONA
}

\author{
by Pierre D. Glynn ${ }^{1}$ and Eurybiades Busenberg ${ }^{1}$
}

Sampling of dissolved gases and chlorofluorocarbons in ground waters at the Pinal Creek toxic waste site was conducted in November 1991. Dissolved nitrogen and dissolved argon concentrations were used to calculate recharge temperatures and excess air trapped during recharge. The average recharge temperature was about $12 \pm 2^{\circ} \mathrm{C}, 6$ to $7^{\circ} \mathrm{C}$ colder than the average ground water temperatures. Excess air concentrations were up to 11 milliliters per liter, indicating very rapid recharge probably during flooding events in the winter and early spring. This hypothesis is supported by local precipitation and air temperature records as well as by the temperature of $10^{\circ} \mathrm{C}$ recorded for Pinal Creek during a large recharge event in February 1993. Nitrogen production by denitrification is not thought to be significant. Dissolved oxygen concentrations are high in all uncontaminated ground waters, a finding consistent with low organic carbon contents in the aquifer. High carbon dioxide partial pressures $\left(\mathrm{pCO}_{2}\right)$ were measured in the contaminated ground waters, particularly in the neutralized contaminated ground waters. Dissolution of carbonate minerals by acidic contaminated ground water is thought responsible for the high $\mathrm{pCO}_{2}$ values. Chlorofluorocarbon-12 (CFC-12) and chlorofluorocarbon-11 (CFC-11) concentrations decrease with depth and distance downgradient in the metal- and acid-contaminated ground waters. CFC-12 concentrations are abnormally high and are thought to result from historically higher-than-normal atmospheric concentrations rather than from direct point-source ground water contamination. Ground water recharge dates calculated from CFC-11 concentrations are reasonable, giving ages of 3 to 15 years for acidic contaminated ground waters, 20 to 30 years for neutralized contaminated ground waters. Deep uncontaminated ground waters have no significant CFC-11 or CFC-12 concentrations, and are believed to more than 50 years old. The CFC-11 recharge dates are consistent with available tritium, deuterium, oxygen-18, and dissolved-gas data.

1 U.S. Geological Survey, Water Resources Division, Reston, VA 


\title{
EXPERIMENTAL STUDIES OF TRACE-METAL PARTITIONING IN PERENNIAL REACHES OF ?INAL CREEK, ARIZONA
}

\author{
by Christopher C. Fuller ${ }^{1}$
}

\begin{abstract}
Development of solute transport models to predict the fate of metal contaminants in Pinal Creek will require quantification the reactions controlling metal partitioning. Manganese oxides are thought to control dissolved tracemetal concentrations in the perennial flow of the creek. However, these process are not adequately characterized. Laboratory experiments under geochemical conditions relevant to Pinal Creek using field-derived materials are proposed to evaluate metal uptake by coprecipitation with manganese $(\mathrm{Mn})$ during oxidation and precipitation of $\mathrm{Mn}$ oxides and by adsorption onto absorbent phases present in the streambed sediments. The reversibility of the metal sorption by these processes also will be investigated.
\end{abstract}

${ }^{1}$ U.S. Geological Survey, Menlo Park, California 


\title{
ASSOCIATION OF SELECTED METALS WITH COLLOIDAL AND SUSPENDED PARTICULATE MATERIAL IN SHALLOW GROUND WATER AND SURFACE WATER AT PINAL CREEK, ARIZONA
}

\author{
By Judson W. Harvey ${ }^{1}$ and Christopher C. Fuller ${ }^{1}$
}

Trace metals are potentially transportable as solid phases in ground water and surface water in association with colloids or suspended particulates. Field data that specifies the partitioning of metals between dissolved and suspended solid phases is necessary for developing physically based models of metal transport. The purpose of the present study was to determine colloidal and suspended-particulate concentrations for selected metals in shallow ground water and in streamflow of the perennial reach of Pinal Creek during base-flow conditions. Concentrations of manganese $(\mathrm{Mn})$, iron $(\mathrm{Fe})$, nickel $(\mathrm{Ni})$, copper $(\mathrm{Cu})$, and cobalt $(\mathrm{Co})$ were measured in unfiltered water samples, and compared with $0.45 \mu \mathrm{m}$ (micrometer) and $0.001 \mu \mathrm{m}$ filtrates of the same water samples. Total metal concentrations in unfiltered water were partitioned into suspended particulate $(>0.45 \mu \mathrm{m})$, colloidal $(0.001-0.45 \mu \mathrm{m})$, and dissolved $(<0.001 \mu \mathrm{m})$ components. Median colloidal and suspended-particulate concentrations for $\mathrm{Mn}, \mathrm{Ni}, \mathrm{Cu}$ and $\mathrm{Co}$ were several percent or less of total concentrations of those metals. In contrast, the sum of Fe colloidal and suspendedparticulate phases was a large percentage of total Fe concentrations in some cases, which indicated that a colloidal or particulate Fe phase was significant at Pinal Creek. At present total Fe concentrations in suspension are low in shallow ground water and in streamflow at Pinal Creek during base-flow conditions. Colloids that do form do not appear to be significant sorbents of other trace metals, compared to $\mathrm{Mn}$ and Fe solid phases on the streambed. Colloid- facilitated metal transport will likely increase in importance if acidic ground water (which has Fe greater than 50 milligrams per liter) reaches Pinal Creek.

${ }^{1}$ U.S. Geological Survey, Menlo Park, Calif. 


\title{
Solute Transport Parameter Estimation for an Injection Experiment at Pinal Creek, Arizona
}

\author{
by Brian J. Wagner and Judson W. Harvey, U.S. Geological Survey, Menlo Park, CA
}

\begin{abstract}
Parameter estimation is an important step in the development of contaminant-transport simulation models. In this paper, we demonstrate an inverse modeling methodology for estimating the transport parameters that characterize the migration, attenuation, and redistribution of contaminants. The inverse model proceeds in two stages: In stage one, a finite difference solute-transport simulation model is coupled with nonlinear least-squares regression to identify the model parameter values that 'best' reproduce the measured solute concentrations. In stage two, solute-transport simulation is combined with first-order uncertainty analysis to quantify parameter-estimate uncertainty. The methodology is widely applicable to transport models for ground-water and stream systems; here we demonstrate the application to a stream system. Using data from an injection experiment at Pinal Creek, Arizona, the inverse model is applied to analyze parameters for a onedimensional solute-transport model with advection, dispersion, lateral inflow, and transient storage. The parameters estimated by the inverse model are dispersion coefficient, stream cross-sectional area, storage-zone cross-sectional area, and stream-storage exchange coefficient. The parameter estimates and associated uncertainties support the interpretation that the transient-storage mechanism is active in Pinal Creek. A discussion of concentration sensitivity to these four estimated parameters is presented to explain how analysis of uncertainties in parameter estimates can be used to identify sampling strategies for reliable parameter estimation.
\end{abstract}




\title{
ALTERATION OF ALLUVIUM BY ACIDIC GROUND WATER RESULTING FROM COPPER MINING AT PINAL CREEK, ARIZONA,
}

\author{
by Carol J. Lind ${ }^{1}$ and Kenneth G. Stollenwerk ${ }^{2}$
}

A composited core of alluvium collected downgradient from a metal-rich, acidic ground-water plume was eluted with ground water from the plume in a column experiment.

The major minerals present in the alluvium before and after elution were identified, and resulting changes in mineral content and in ground-water composition were correlated. Of the 12 identified minerals, the ground water dissolved two carbonate minerals and pyrolusite and partially dissolved the feldspars.

${ }^{1}$ U.S. Geological Survey, Menlo Park, CA ${ }_{2}$ U.S. Geological Survey, Denver, CO 


\title{
RELATIONS AMONG ALGAL SPECIES AND CHEMICAL GRADIENTS IN PINAL CREEK, NEAR GLOBE, ARIZONA
}

by Patrice H. Spindler and Milton R. Sommerfeld ${ }^{2}$

\begin{abstract}
The relations among algal species and water chemistry in Pinal Creek, near Globe, Arizona, were investigated. Water, sediment, and periphyton samples were collected from seven sites during 1991-92. Fourteen species of algae and 16 chemical properties were selected for correlation and cluster analyses. Three major algal associations in Pinal Creek were identified by cluster analysis: an acid- and metal-tolerant association at upstream sites, an alkalophilous association at downstream sites, and an association of ubiquitously distributed opportunistic species. Indicator species of the acid- and metal-rich environment at upstream sites were Microspora stagnorum, Surirella minuta and Ulothrix variabilis. The exclusion of Nitzschia linearis and Vaucheria geminata from upstream sites and their abundance at downstream sites suggest that these species are acid and metal intolerant.
\end{abstract}

1 Formerly graduate student at Department of Botany, Arizona State University, Tempe, Arizona 85287; now employed at the Arizona Department of Environmental Quality, office of Water Quality, Clean Lakes Program, 3033 N. Central Ave., Phoenix, Arizona 85012.

2 Department of Botany, Arizona State University, Tempe, Arizona 85287 . 
